National Water-Quality Assessment Program

\title{
Chloride in Groundwater and Surface Water in Areas Underlain by the Glacial Aquifer System, Northern United States
}

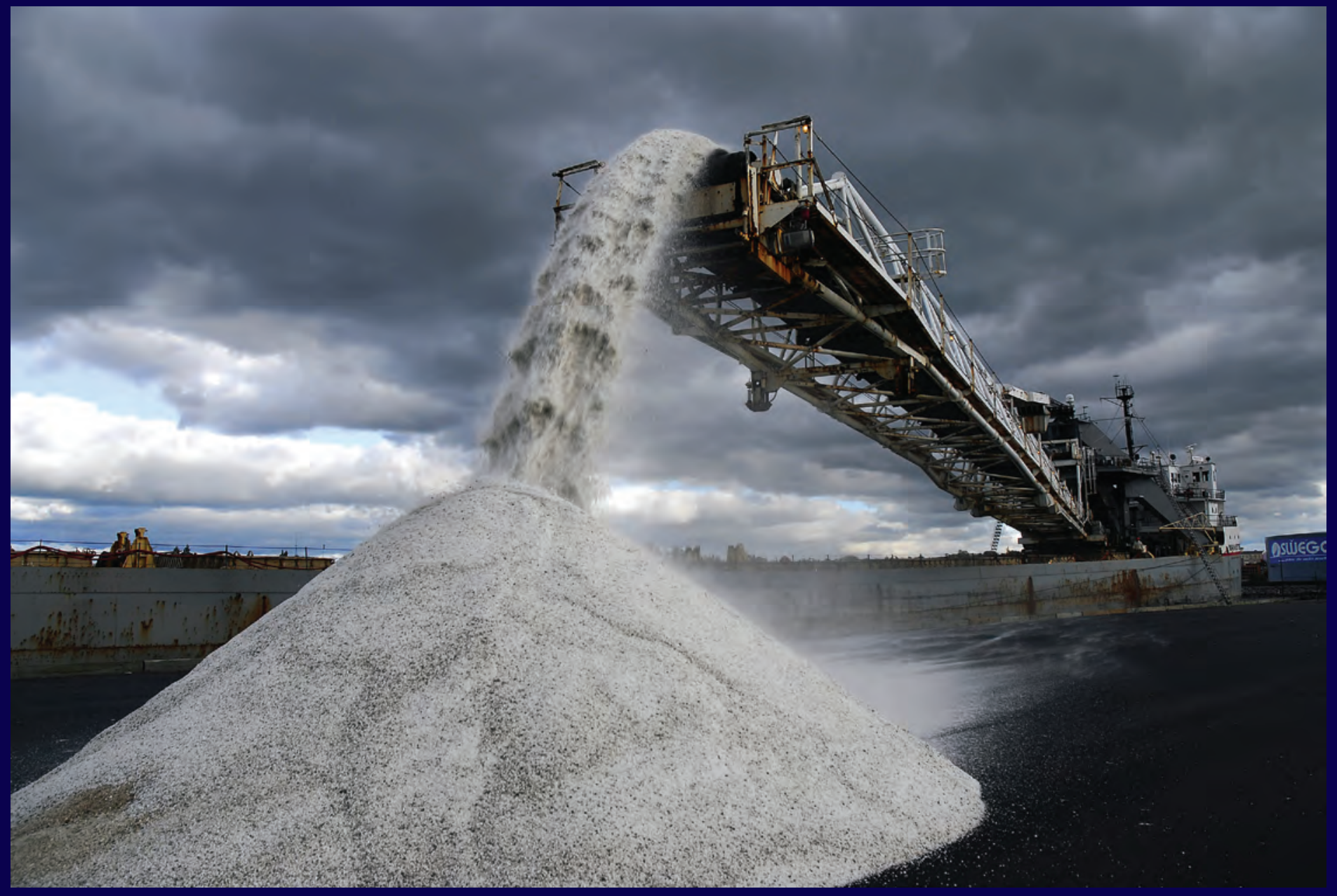

Scientific Investigations Report 2009-5086 
Cover. Rock salt being unloaded off of a ship in Oswego, New York, October, 2007 (James Rajotte/The New York Times/Redux) 


\section{Chloride in Groundwater and Surface Water in Areas Underlain by the Glacial Aquifer System, Northern United States}

By John R. Mullaney, David L. Lorenz, and Alan D. Arntson

National Water-Quality Assessment Program

Scientific Investigations Report 2009-5086 


\title{
U.S. Department of the Interior \\ KEN SALAZAR, Secretary
}

\author{
U.S. Geological Survey \\ Suzette M. Kimball, Acting Director
}

U.S. Geological Survey, Reston, Virginia: 2009

For product and ordering information:

World Wide Web: http://www.usgs.gov/pubprod

Telephone: 1-888-ASK-USGS

For more information on the USGS — the Federal source for science about the Earth, its natural and living resources, natural hazards, and the environment:

World Wide Web: http://www.usgs.gov

Telephone: 1-888-ASK-USGS

Any use of trade, product, or firm names is for descriptive purposes only and does not imply endorsement by the U.S. Government.

Although this report is in the public domain, permission must be secured from the individual copyright owners to reproduce any copyrighted materials contained within this report.

Suggested citation:

Mullaney, J.R., Lorenz, D.L., Arntson, A.D., 2009, Chloride in groundwater and surface water in areas underlain by the glacial aquifer system, northern United States: U.S. Geological Survey Scientific Investigations Report 2009-5086, $41 \mathrm{p}$. 


\section{Foreword}

The U.S. Geological Survey (USGS) is committed to providing the Nation with credible scientific information that helps to enhance and protect the overall quality of life and that facilitates effective management of water, biological, energy, and mineral resources (http://www.usgs.gov/. Information on the Nation's water resources is critical to ensuring long-term availability of water that is safe for drinking and recreation and is suitable for industry, irrigation, and fish and wildlife. Population growth and increasing demands for water make the availability of that water, now measured in terms of quantity and quality, even more essential to the long-term sustainability of our communities and ecosystems.

The USGS implemented the National Water-Quality Assessment (NAWQA) Program in 1991 to support national, regional, State, and local information needs and decisions related to water-quality management and policy (http://water.usgs.gov/nawqa). The NAWQA Program is designed to answer: What is the condition of our Nation's streams and groundwater? How are conditions changing over time? How do natural features and human activities affect the quality of streams and groundwater, and where are those effects most pronounced? By combining information on water chemistry, physical characteristics, stream habitat, and aquatic life, the NAWQA Program aims to provide science-based insights for current and emerging water issues and priorities. From 1991-2001, the NAWQA Program completed interdisciplinary assessments and established a baseline understanding of water-quality conditions in 51 of the Nation's river basins and aquifers, referred to as Study Units (http://water.usgs.gov/nawqa/studyu.htm).

In the second decade of the Program (2001-2012), a major focus is on regional assessments of waterquality conditions and trends. These regional assessments are based on major river basins and principal aquifers, which encompass larger regions of the country than the Study Units. Regional assessments extend the findings in the Study Units by filling critical gaps in characterizing the quality of surface water and groundwater, and by determining status and trends at sites that have been consistently monitored for more than a decade. In addition, the regional assessments continue to build an understanding of how natural features and human activities affect water quality. Many of the regional assessments employ modeling and other scientific tools, developed on the basis of data collected at individual sites, to help extend knowledge of water quality to unmonitored, yet comparable areas within the regions. The models thereby enhance the value of our existing data and our understanding of the hydrologic system. In addition, the models are useful in evaluating various resource-management scenarios and in predicting how our actions, such as reducing or managing nonpoint and point sources of contamination, land conversion, and altering flow and (or) pumping regimes, are likely to affect water conditions within a region.

Other activities planned during the second decade include continuing national syntheses of information on pesticides, volatile organic compounds (VOCs), nutrients, selected trace elements, and aquatic ecology; and continuing national topical studies on the fate of agricultural chemicals, effects of urbanization on stream ecosystems, bioaccumulation of mercury in stream ecosystems, effects of nutrient enrichment on stream ecosystems, and transport of contaminants to public-supply wells.

The USGS aims to disseminate credible, timely, and relevant science information to address practical and effective water-resource management and strategies that protect and restore water quality. We hope this NAWQA publication will provide you with insights and information to meet your needs, and will foster increased citizen awareness and involvement in the protection and restoration of our Nation's waters.

The USGS recognizes that a national assessment by a single program cannot address all water-resource issues of interest. External coordination at all levels is critical for cost-effective management, regulation, and conservation of our Nation's water resources. The NAWQA Program, therefore, depends on advice and information from other agencies_-Federal, State, regional, interstate, Tribal, and local—as well as nongovernmental organizations, industry, academia, and other stakeholder groups. Your assistance and suggestions are greatly appreciated.

Matthew C. Larsen

Associate Director for Water 



\section{Contents}

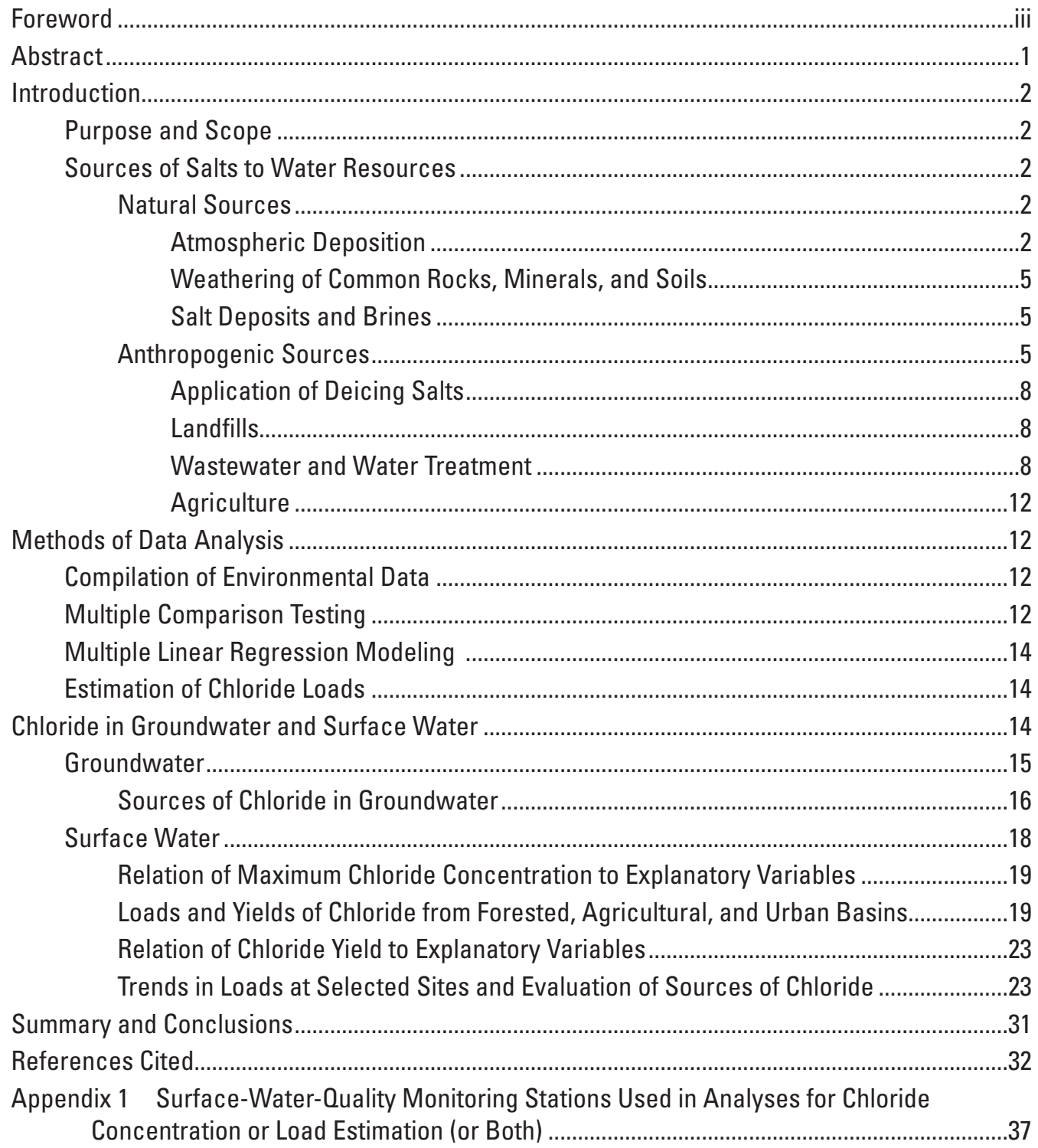




\section{Figures}

1. Graphs showing-

1. Salt use and consumption in the United States by (A) all end users, 1975-2003, and $(B)$ consumption by use or industry, 1975-2005.

2-5. Maps showing-

2. Glacial aquifer system and National Water-Quality Assessment Program study basins, northern United States.

3. Mean wet deposition of chloride, 1994-2003, and locations of salt mining in the glacial aquifer system study area, northern United States.

4. Estimated average concentration of chloride, 1994-2002, in runoff attributable to atmospheric (wet) deposition in the glacial aquifer system study area, northern United States.

5. Wells and surface-water-quality monitoring stations used in the analysis of the glacial aquifer system study area, northern United States

6-17. Graphs showing-

6. Distribution of chloride concentrations in samples from shallow monitoring wells in forested, agricultural, and urban areas and in drinking-water supply wells in the glacial aquifer system, northern United States, 1991-2003 ..

7. Distribution of sodium concentrations in samples from shallow monitoring wells in forested, agricultural, and urban areas and in drinking-water supply wells in the glacial aquifer system, northern United States, 1991-2003 ....

8. Distribution of chloride:bromide ratios (by mass) in samples from shallow monitoring wells in forested, agricultural, and urban areas and in drinking-water supply wells in the glacial aquifer system, northern United States, 1991-2003.

9. (A) Binary mixing curves representing sources of chloride. The relation of chloride concentration to chloride:bromide ratios (by mass) for samples from shallow monitoring wells in $(B)$ forested areas, $(C)$ agricultural areas, and (D) urban areas.

10. Distribution of chloride:bromide ratios (by mass) in samples from drinkingwater supply wells in geographic regions of the glacial aquifer system, northern United States, 1991-2003

11. Distribution of maximum chloride concentrations measured at selected surface-water-quality monitoring stations in the glacial aquifer system, northern United States, 1991-2004

12. Chloride concentrations, snow depth, and discharge at station 05288705 , Shingle Creek at Queen Avenue in Minneapolis, Minnesota, February 1997.

13. Chloride concentrations in base flow, plotted against maximum measured chloride concentrations at selected forested, agricultural, and urban basins in the glacial aquifer system, northern United States, 1991-2004 
14. Predicted natural log of maximum measured chloride concentrations from multiple linear regression modeling, and observed natural log of maximum measured chloride concentrations in selected forested, agricultural, and urban basins in the glacial aquifer system, northern United States, 1991-2004....28

15. Distribution of annual mean chloride yields at selected surface-water-quality monitoring stations in the glacial aquifer system, northern United States, 1991-2003.

16. Predicted natural log of annual chloride yield from multiple linear regression modeling and observed natural log of chloride yield in selected forested, agricultural, and urban basins in the glacial aquifer system, northern United States, 1991-2003...

17. Chloride loads with time at selected water-quality monitoring stations in the glacial aquifer system, northern United States: (A) Poplar Creek at Elgin, Illinois, water years 1978-2003; (B) Quinnipiac River at Wallingford, Connecticut, water years 1969-2003; and (C) Rahway River near Springfield, New Jersey, water years 1980-2003.

\section{Tables}

1. Estimated wet deposition of chloride on the glacial aquifer system, northern United States, 1994-2003.

2. Selected annual application rates of deicing chemicals on State and local roads in the glacial aquifer system, northern United States

3. Watershed characteristics evaluated in a regression analysis of maximum measured chloride concentrations

4. Chloride:bromide ratios for sources of chloride to water resources ..............................22

5. Monitoring stations where surface waters had chloride concentrations greater than 230 milligrams per liter in the glacial aquifer system, northern United States, 1991-2004.

6. Multiple linear-regression estimates of model coefficients, standard errors, $t$-statistic and $p$-values for the dependent variable natural log of maximum measured chloride concentration in surface water for selected urban, agricultural, and forested basins, in the glacial aquifer system, northern United States, 1991-2004.

7. Multiple linear regression estimates of model coefficients and standard errors, $t$-statistics, and $p$-values for the dependent variable natural log of chloride yield, selected forested, agricultural and urban basins in the glacial aquifer system, northern United States, 1991-2003 


\section{Conversion Factors}

\begin{tabular}{|c|c|c|}
\hline Multiply & By & To obtain \\
\hline \multicolumn{3}{|c|}{ Length } \\
\hline inch (in.) & 2.54 & centimeter $(\mathrm{cm})$ \\
\hline inch (in.) & 25.4 & millimeter (mm) \\
\hline foot (ft) & 0.3048 & meter $(\mathrm{m})$ \\
\hline mile $(\mathrm{mi})$ & 1.609 & kilometer $(\mathrm{km})$ \\
\hline \multicolumn{3}{|c|}{ Area } \\
\hline square mile $\left(\mathrm{mi}^{2}\right)$ & 259.0 & hectare (ha) \\
\hline square mile $\left(\mathrm{mi}^{2}\right)$ & 2.590 & square kilometer $\left(\mathrm{km}^{2}\right)$ \\
\hline \multicolumn{3}{|c|}{ Volume } \\
\hline gallon (gal) & 3.785 & liter (L) \\
\hline gallon (gal) & 0.003785 & cubic meter $\left(\mathrm{m}^{3}\right)$ \\
\hline gallon (gal) & 3.785 & cubic decimeter $\left(\mathrm{dm}^{3}\right)$ \\
\hline million gallons (Mgal) & 3,785 & cubic meter $\left(\mathrm{m}^{3}\right)$ \\
\hline cubic foot $\left(\mathrm{ft}^{3}\right)$ & 28.32 & cubic decimeter $\left(\mathrm{dm}^{3}\right)$ \\
\hline cubic foot $\left(\mathrm{ft}^{3}\right)$ & 0.02832 & cubic meter $\left(\mathrm{m}^{3}\right)$ \\
\hline \multicolumn{3}{|c|}{ Flow rate } \\
\hline cubic foot per second $\left(\mathrm{ft}^{3} / \mathrm{s}\right)$ & 0.02832 & cubic meter per second $\left(\mathrm{m}^{3} / \mathrm{s}\right)$ \\
\hline million gallons per day (Mgal/d) & 0.04381 & cubic meter per second $\left(\mathrm{km}^{3} / \mathrm{s}\right)$ \\
\hline inch per year (in/yr) & 25.4 & millimeter per year $(\mathrm{mm} / \mathrm{yr})$ \\
\hline \multicolumn{3}{|c|}{ Mass } \\
\hline ounce, avoirdupois (oz) & 28.35 & gram $(\mathrm{g})$ \\
\hline pound, avoirdupois (lb) & 0.4536 & kilogram (kg) \\
\hline ton, short $(2,000 \mathrm{lb})$ & 0.9072 & megagram $(\mathrm{Mg})$ \\
\hline ton per year (ton/yr) & 0.9072 & megagram per year $(\mathrm{Mg} / \mathrm{yr})$ \\
\hline ton per year (ton/yr) & 0.9072 & metric ton per year \\
\hline tons per square mile (ton $/ \mathrm{mi}^{2}$ ) & 350.1947 & $\begin{array}{l}\text { kilograms per square kilometer } \\
\qquad\left(\mathrm{kg} / \mathrm{km}^{2}\right)\end{array}$ \\
\hline pound (lb) & $453,592.4$ & milligram (mg) \\
\hline pounds per day $(\mathrm{lb} / \mathrm{d})$ & $453,592.4$ & milligram per day $(\mathrm{mg} / \mathrm{d})$ \\
\hline pound (lb) & 0.4535924 & kilogram $(\mathrm{kg})$ \\
\hline
\end{tabular}

Concentrations of chemical constituents in water are given in milligrams per liter $(\mathrm{mg} / \mathrm{L})$.

Horizontal coordinate information is referenced to the North American Datum of 1983 (NAD 83). 


\title{
Chloride in Groundwater and Surface Water in Areas Underlain by the Glacial Aquifer System, Northern United States
}

\author{
By John R. Mullaney, David L. Lorenz, and Alan D. Arntson
}

\section{Abstract}

A study of chloride in groundwater and surface water was conducted for the glacial aquifer system of the northern United States in forested, agricultural, and urban areas by analyzing data collected for the National Water-Quality Assessment Program from 1991 to 2004.

Groundwater-quality data from a sampling of 1,329 wells in 19 states were analyzed. Chloride concentrations were greater than the secondary maximum contaminant level established by the U.S. Environmental Protection Agency of 250 milligrams per liter in 2.5 percent of samples from 797 shallow monitoring wells and in 1.7 percent of samples from 532 drinking-water supply wells. Water samples from shallow monitoring wells in urban areas had the largest concentration of chloride, followed by water samples from agricultural and forested areas (medians of 46, 12, and 2.9 milligrams per liter, respectively).

An analysis of chloride:bromide ratios, by mass, and chloride concentrations compared to binary mixing curves for dilute groundwater, halite, sewage and animal waste, potassium chloride fertilizer, basin brines, seawater, and landfill leachate in samples from monitoring wells indicated multiple sources of chloride in samples from wells in urban areas and agricultural areas. Water from shallow monitoring wells in urban areas had the largest chloride:bromide ratio, and samples with chloride:bromide ratios greater than 1,000 and chloride concentrations greater than 100 milligrams per liter were dominated by halite; however, the samples commonly contained mixtures that indicated input from sewage or animal waste. Chloride:bromide ratios were significantly larger in samples from public-supply drinking-water wells than from private drinking-water wells, and ratios were significantly larger in all drinking-water wells in eastern and central regions of the glacial aquifer system than in west-central and western regions of the glacial aquifer system.
Surface-water-quality data collected regularly during varying time periods from 1991-2004 from 100 basins dominated by forested, agricultural, or urban land in 15 states were analyzed to determine maximum measured chloride concentrations. Samples from 15 sites in east, central, and west-central areas, collected primarily in winter, had chloride concentrations higher than the U.S. Environmental Protection Agency recommended chronic criterion concentration for aquatic life of 230 milligrams per liter. Concentrations of chloride in baseflow samples were predictive of maximum measured chloride concentrations, indicating that inputs of chloride from groundwater and (or) point-source wastewater discharges increase the likelihood of samples exceeding the recommended chronic aquatic criterion. Multiple linear regression analyses showed that the density of major roads, potential evapotranspiration, and the percentage of annual runoff from saturated overland flow were significant factors in describing the range of maximum measured chloride concentrations in the basins studied.

Chloride loads and yields were determined at 95 surfacewater-monitoring stations in basins dominated by forested, agricultural, or urban land. Annual chloride yield was largest in the urban basins (median of 88 tons per square mile) and smallest in the forested basins (median of 6.4 tons per square mile). The median chloride yield in the agricultural basins was 15.4 tons per square mile. Multiple linear regression analyses showed that the density of highways (roads in U.S. highway system), the number of major wastewater discharges in the basin, potential evapotranspiration, and urban minus agricultural land area were significant factors in describing the range of average annual chloride yields.

Upward trends in chloride loads were apparent in several urban basins for which additional long-term data were available. Increases in chloride loads over time may be related to a variety of factors, including increases in road area and consequent deicing, increases in wastewater and septic-system discharges, recycling of chloride from drinking water, and leachate from landfills and salt storage areas. 


\section{Introduction}

The use of salt has increased measurably in the United States since 1950 (Kostick, 1993; Kostick and others, 2007) (fig. 1A), and the major increase in the use of salt has been for deicing of roads, parking lots, and other impervious surfaces during the winter months (fig. 1B). The application of salt for deicing these surfaces has raised awareness of potential adverse effects on water resources (Bubeck and others, 1971; Huling and Hollocher, 1972; Wulkowicz and Saleem, 1974).

Widespread upward trends in chloride concentrations in streams nationwide have been reported from 1974-81 (Smith and others, 1987). Similar trends have been reported in Connecticut from the 1970s to the 1990s (Trench, 1996; Colombo and Trench, 2002) and in New Jersey (Hay and Campbell, 1990; Robinson and others, 1996). Several studies have shown elevated concentrations of chloride and sodium in glacial aquifers related to urban land use (Grady and Mullaney, 1998; Fong, 2000; Thomas, 2000; Savoca and others, 2000).

The primary concern for water quality is the degradation of groundwater and surface water that may be used for drinking-water supply or for aquatic habitat. The U.S. Environmental Protection Agency (USEPA) has set a secondary maximum contaminant level (SMCL) of $250 \mathrm{mg} / \mathrm{L}$ for chloride in drinking water (U.S. Environmental Protection Agency, 1992). The SMCL for chloride is an unenforceable guideline that relates to the aesthetics of the water and the perceived salty taste of water at concentrations above $250 \mathrm{mg} / \mathrm{L}$. The USEPA-recommended chronic criterion for aquatic life is a 4-day average chloride concentration of 230 $\mathrm{mg} / \mathrm{L}$ with an occurrence interval of once every 3 years, and the recommended acute criterion concentration for chloride is $860 \mathrm{mg} / \mathrm{L}$ (U.S. Environmental Protection Agency, 1988). The acute criterion relates to a 1-hour average concentration with a recurrence interval of less than once every 3 years. Other concerns regarding salt inputs include the effects of cationexchange reactions on the quality of water (Granato and others, 1995).

The U.S. Geological Survey (USGS) has been collecting data since 1991 on the quality of water in the Nation's aquifers and streams through the National Water-Quality Assessment (NAWQA) Program. Data are synthesized at the scale of regional principal aquifers (Lapham and others, 2005) to understand water-quality issues affecting aquifers used commonly for domestic and public water supply. The glacial aquifer system (Warner and Arnold, 2005) is the largest principal aquifer (fig. 2) in the United States, in terms of areal extent and its use as a source for drinking water. The glacial aquifer system is considered here to include all unconsolidated aquifers overlying bedrock north of the line of continental glaciation. Warner and Arnold (2005) divided the glaciated area in the United States into four major glacial regions (fig. 2) based on differing glacial source material: east, central, westcentral and west.
The glacial aquifer system also is a source of surface water, because the aquifer and stream systems are commonly in hydraulic connection. Therefore, the discharge of groundwater to streams affects the quality of surface water, and surface water at times can become a source of groundwater.

\section{Purpose and Scope}

This report describes the concentrations of salt-related constituents (primarily chloride) in shallow groundwater and surface water in the glaciated northern United States, on the basis of water-quality data collected from 1991 to 2004 for the USGS NAWQA Program at 1,329 wells in 19 states and 100 surface-water sites in 15 states. The report presents information on natural and anthropogenic sources of chloride in the environment, concentrations of sodium and chloride in groundwater, concentrations of chloride in surface water, and estimates of chloride loads and yields from selected basins in the study area. The report also provides information on the relation between ancillary variables (land-use, land-cover, hydrologic, and climatic variables) and the concentrations and yields of chloride in surface water.

Groundwater data analyzed for this study generally were collected from coarse-grained glacial aquifers, and therefore the results may not translate to other areas in the glacial aquifer where coarse-grained deposits are absent, and the surficial material is glacial till or bedrock.

\section{Sources of Salts to Water Resources}

\section{Natural Sources}

Natural sources of salts to water resources include (1) the oceans; (2) the natural weathering of bedrock, surficial materials, and soils; (3) geologic deposits containing halite, or saline groundwater (brines); and (4) volcanic activity.

The oceans typically contain about 19,000 milligrams per liter (mg/L) of chloride (Feth, 1981). Sodium and chloride are the most abundant ions present in the atmosphere above the oceans, and atmospheric deposition of chloride and sodium from the oceans is highest along coastal areas. Atmospheric deposition may contain natural sources of chloride from the oceans, and dusts from surficial salt deposits such as in playa lakes, as well as chloride from anthropogenic sources, such as manufacturing and power generation.

\section{Atmospheric Deposition}

From 1994 to 2003, wet deposition of chloride contributed an average of 0.04 to $6.2 \mathrm{ton} / \mathrm{mi}^{2}$ to the glacial aquifer system study area (table 1, fig. 3) based on the data from the National Atmospheric Deposition Program (NADP) (2006). The largest amount of wet deposition of chloride was on the eastern and western coastal parts of the study area, including the Puget Sound area and the New England coastal basins. The 


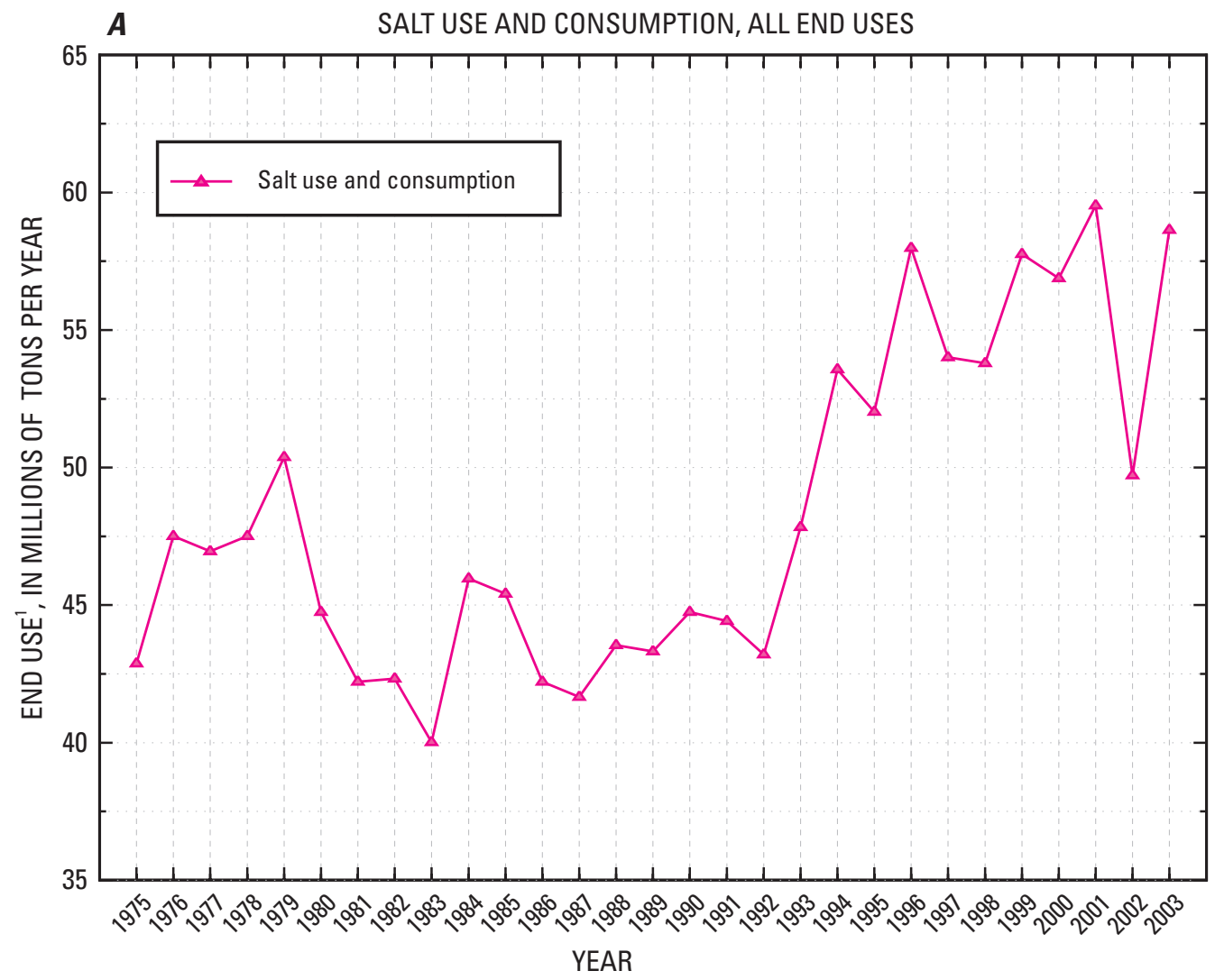

B

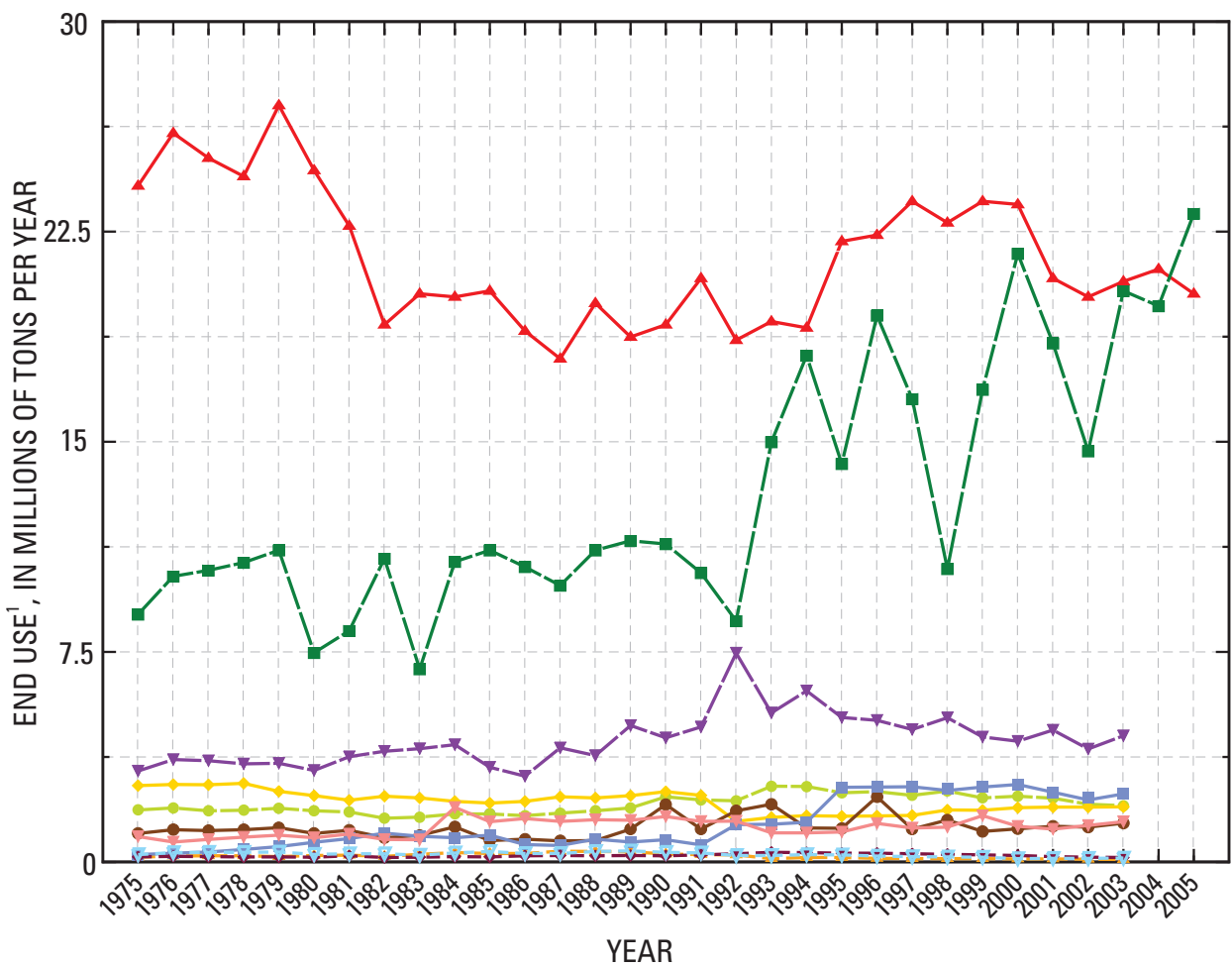

EXPLANATION

- - Agriculture

_ـ Alkalies and chlorine

- - Deicing

$\longrightarrow$ Food products

- - - - - - Metal production

$\longrightarrow$ Other chemicals

- - - - Paper products

$\longrightarrow$ Petroleum

$--\bullet \quad$ Textiles and dyeing

$\longrightarrow$ Water treatment

$\longrightarrow \rightarrow-0$ ther uses ${ }^{2}$

${ }^{1}$ End use is defined as the use of the mineral commodity in a particular industrial sector or product.

${ }^{2}$ The other uses category includes salt used in rubber, tanning and/or leather, industrial, institutional (commercial stores) and other wholesalers and retailers,

U.S. Government resale, some exports for consumption in overseas territories administered by the United States, and other various minor uses (U.S. Geological Survey, 2005b).

Figure 1. Salt use and consumption in the United States by (A) all end users, 1975-2003 (data from U.S. Geological Survey, 2005b), and (B) consumption by use or industry, 1975-2005 (data from U.S. Geological Survey, 2005b; Kostick and others, 2007). 


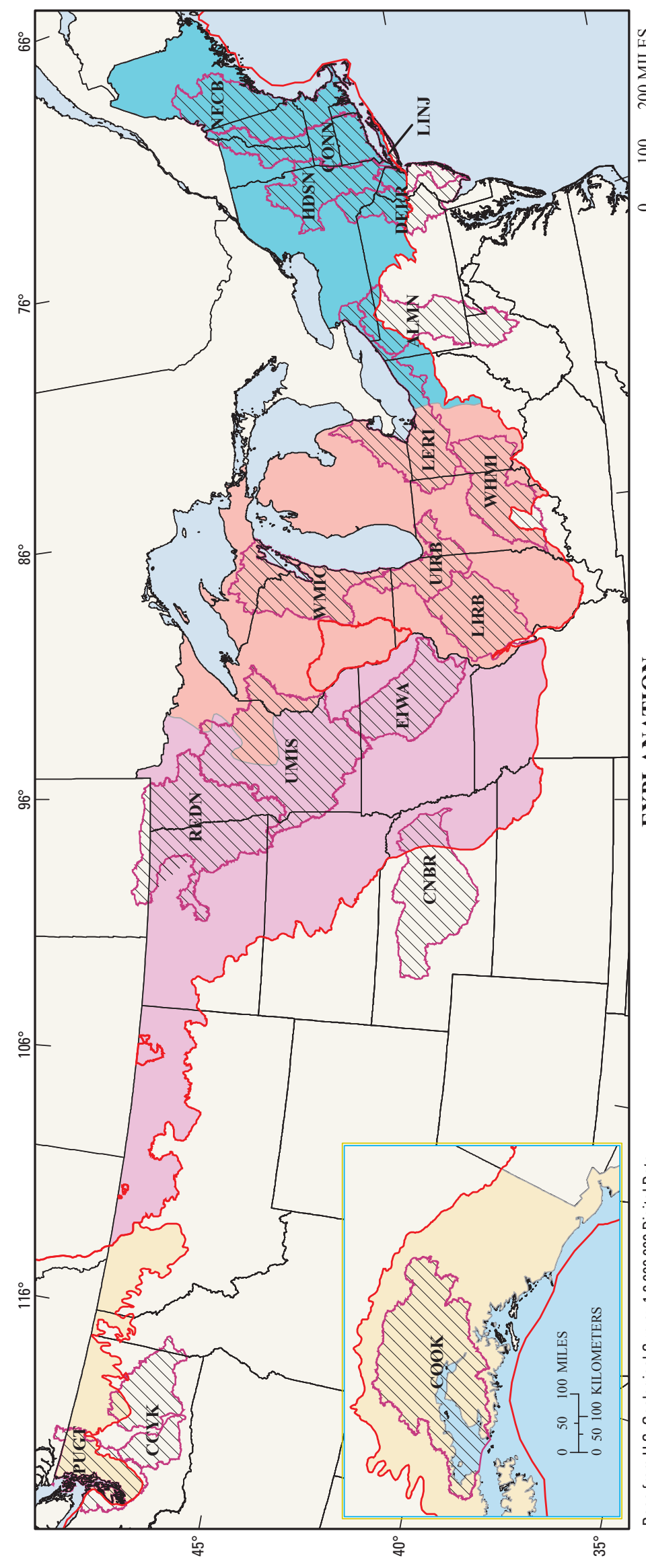

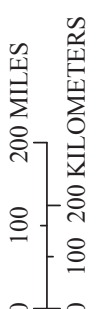

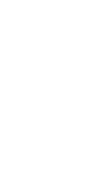

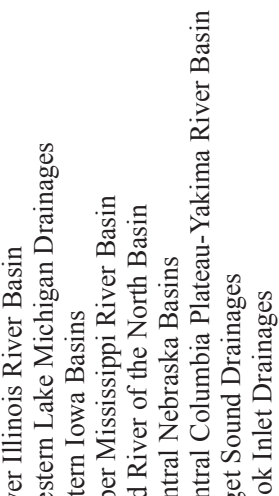

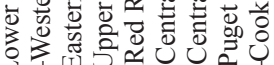

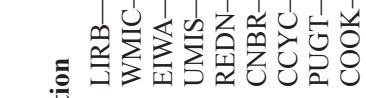

zó

造

.

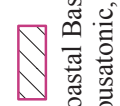

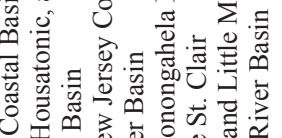

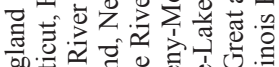

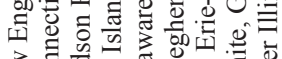

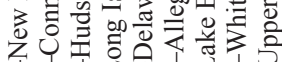

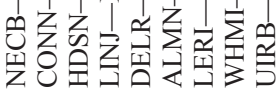

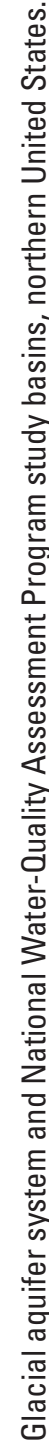

离 
Table 1. Estimated wet deposition of chloride on the glacial aquifer system, northern United States, 1994-2003.

[Values are in tons per square mile per year. Data analyzed from the National Atmospheric Deposition Program, 2006]

\begin{tabular}{lccc}
\hline \multicolumn{1}{c}{ Region } & Minimum & Maximum & Mean \\
\hline East & 0.19 & 4.16 & 0.71 \\
Central & .09 & .64 & .25 \\
West central & .04 & .40 & .13 \\
West & .06 & 6.22 & .91 \\
\hline
\end{tabular}

lowest amount of wet deposition of chloride was in the central parts of the study area, including Iowa, Minnesota, North Dakota, and South Dakota. In basins in the United States with little or no human activity, the yield of chloride from streams is correlated with the amount of precipitation. The chloride yield from atmospheric deposition is related to precipitation quantity and has been reported to contribute on average 28 to 62 percent of the chloride yield in undeveloped basins throughout the United States. Basins with crystalline bedrock were associated with the largest percentage of atmospheric chloride yield, followed, in order, by basins underlain by sandstone and basins underlain by limestone (Peters, 1984).

Chloride concentrations in streams and groundwater that originated from wet deposition of chloride are different from concentrations measured in precipitation because of the concentration of chloride by the process of evapotranspiration. The average concentrations of chloride from wet deposition in runoff (surface and groundwater) can be calculated as the wet deposition of chloride divided by the runoff (fig. 4). This calculation indicates that average concentrations in runoff attributable to wet deposition are typically $0.1-2.0 \mathrm{mg} / \mathrm{L}$.

\section{Weathering of Common Rocks, Minerals, and Soils}

In addition to the chloride deposited on a basin by precipitation, there is a natural input from the weathering of rocks and minerals. Chlorine is present in several minerals in common rocks, and its release to waters as chloride ions is generally slow and through processes other than dissolution (Feth, 1981). The chloride in excess of the load from precipitation was attributed to the weathering of the mineral hornblende in glacial tills in two Adirondack Mountain basins in New York (Peters, 1991).

The chloride yields from 21 basins with no permanent residents, underlain by limestone, sandstone, and crystalline rocks, were analyzed by Peters (1984), who concluded, on the basis of a regression analysis, that 77 percent of the variation in chloride yield from these basins could be explained by the quantity of precipitation a basin receives. The relation to precipitation probably includes direct wet deposition of chloride, as well as chemical weathering, which increases with precipitation. A subset of 10 of these basins ${ }^{1}$ with very low population density was identified in the glacial aquifer system. The difference between the chloride yield attributable to direct input from precipitation and the amount attributable to the relation between precipitation and chloride yield probably represents an estimate of the amount derived from chemical weathering. This difference ranged from 0 to 72 percent of the chloride yield. Chloride yields from these 10 basins ranged from 0.7 to 68 tons $/ \mathrm{mi}^{2}$, although all but one site had yields less than or equal to 9 tons $/ \mathrm{mi}^{2}$. The estimated annual load from chemical weathering in these 10 basins, on the basis of the above percentage, ranged from 0 to 2 tons $/ \mathrm{mi}^{2}$ with an average of 0.9 tons $/ \mathrm{mi}^{2}$ (Peters, 1984).

\section{Salt Deposits and Brines}

Bedded salt deposits underlie parts of the study area, including parts of Michigan, Western New York, Ohio, and Pennsylvania (Norris, 1978). New York, Ohio, and Michigan produce much of the rock salt and other salts derived from brines in the United States. Most halite deposits occur at depth or at the downgradient ends of groundwater systems (Feth, 1981) and therefore generally may not affect the shallowgroundwater quality of the glacial aquifer system. Water with high concentrations of dissolved solids is present in sedimentary bedrock at depth in many parts of the study area (Feth, 1965). These halite deposits and brines may be a salinity source for groundwater in zones of flow convergence, where water of different ages and from different aquifers (surficial to deep bedrock) have mixed. Therefore, it is possible that part of the chloride budget for some basins in these areas may be from dissolution of halite deposits or mixing with brines. This component of the chloride budget is evidenced by saline springs in parts of the study area, such as Michigan, Illinois, and New York (Michigan Department of Environmental Quality, 1994; Panno and others, 2006; Rao and others, 2005).

\section{Anthropogenic Sources}

The use of salt in the United States has increased from 42.9 million tons in 1975 to nearly 58.5 million tons in 2005 (Kostick and others, 2007) (fig. 1A). The largest use of salt has been in the chloralkali industry that produces chlorine and sodium hydroxide (Kostick, 1993) (fig. 1B). In 2005, salt used by the chloralkali industry represented 34.7 percent of the end use of salt. The second largest use of salt since 1975 has been deicing. Deicing use has increased since then, and was greater than that for the chloralkali industry in 2005, when it represented 39.5 percent of the end use of salt in the United States (Kostick and others, 2007). Other uses of salt (totaling about 25 percent of end use in 2005) include agriculture, food processing, metal processing, paper production, textiles and dyeing, petroleum production, water treatment, and other

\footnotetext{
${ }^{1}$ Basins included the following stations from Peters (1984), table 1: 4045500, 4057004, 4126520, 4132052, 6452000, 6478500, 1066000, $4014500,5124480,12447390$.
} 

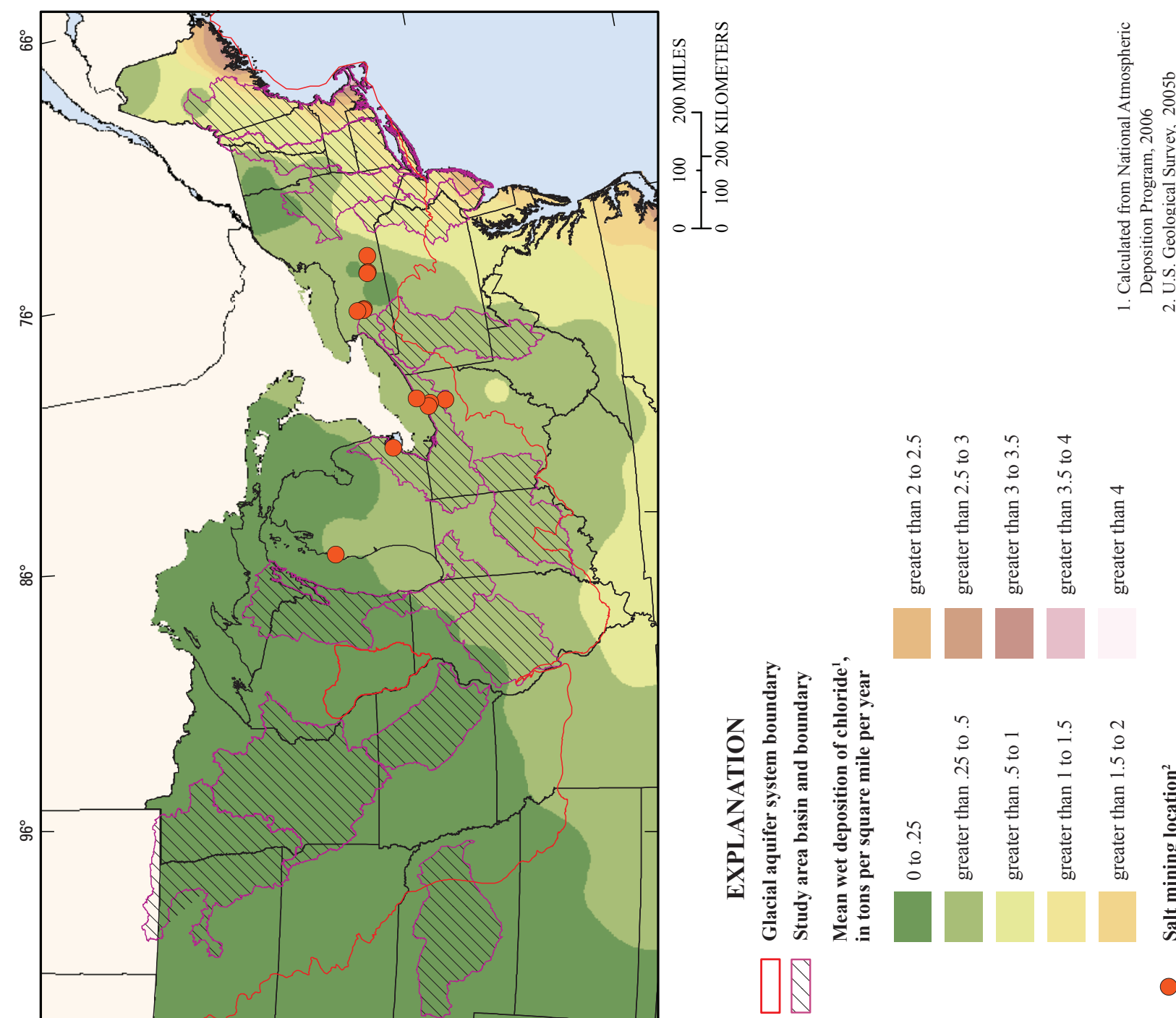

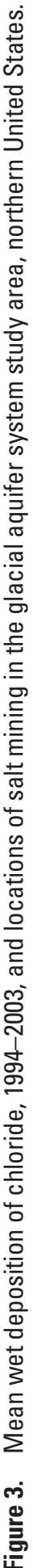




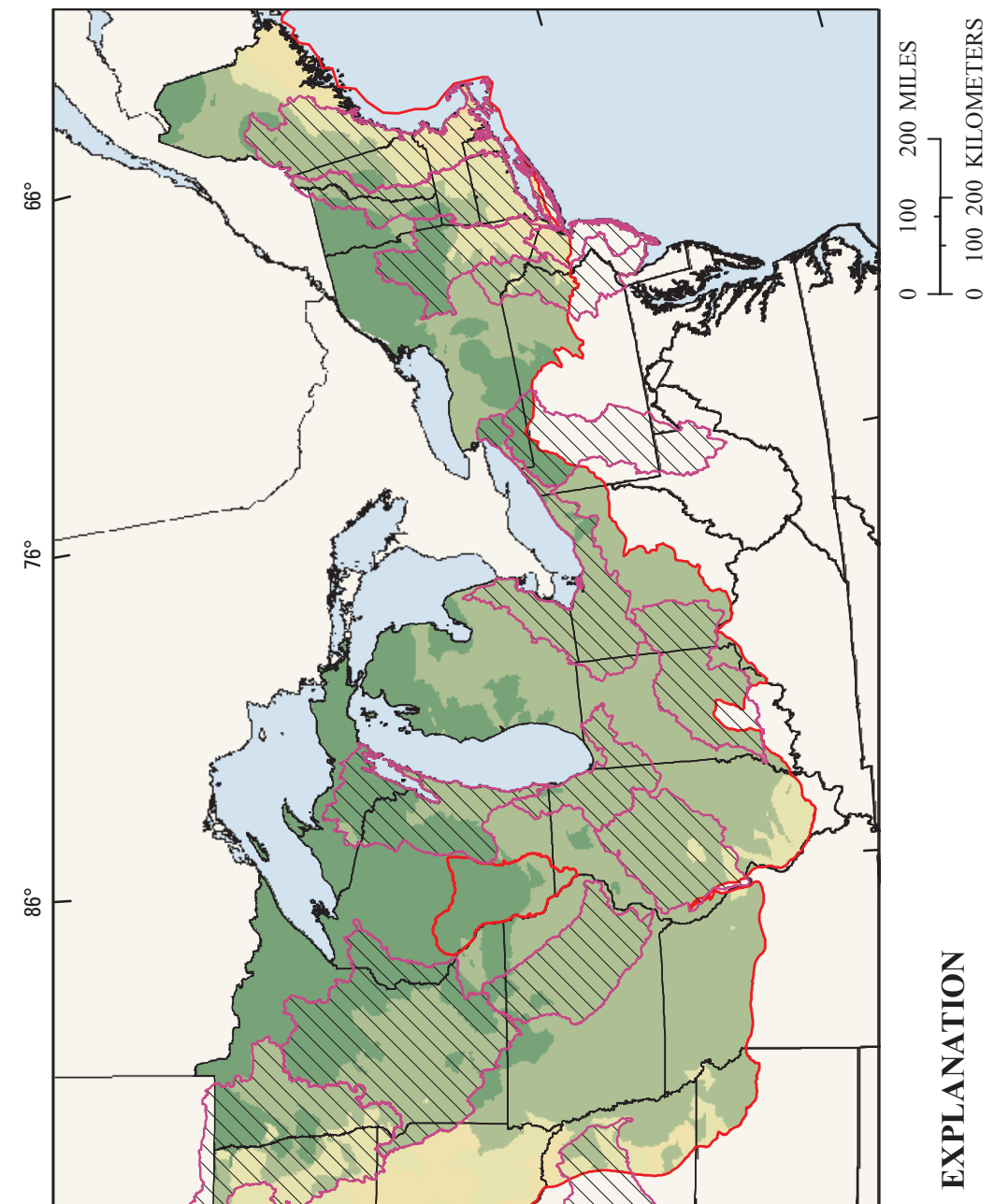

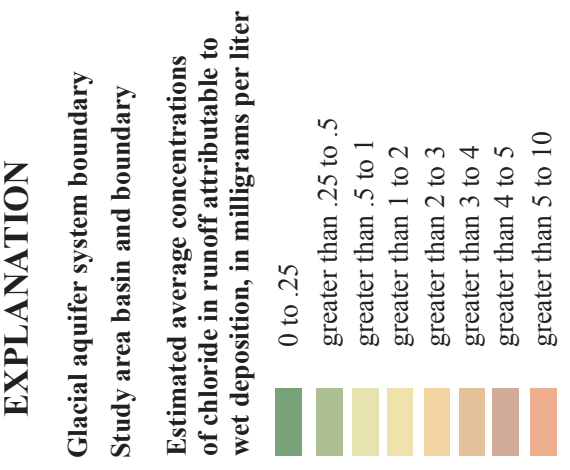

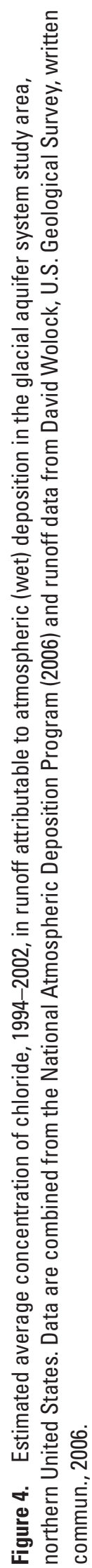


manufacturing (fig. 1B). The northern states that compose the glacial aquifer system (fig. 2) were the end destination for about 76 percent of the shipments of evaporated salt and rock salt (excluding brine) in the United States in 2005 (Kostick and others, 2007).

For many uses of salt, the chloride and sodium may end up being discharged to groundwater and surface waters as a direct or indirect result of use. The common pathways include atmospheric deposition; the dissolution of deicing salts from normal use on streets, parking lots, highways, and other paved surfaces; storage and handling of deicing salt; release of brines from salt, oil, and gas production; leaching from landfills; the treatment of drinking water and wastewater; and discharge of wastewater from treatment facilities or septic systems. The section below describes some of the common pathways for salt to enter the environment from human use.

\section{Application of Deicing Salts}

The use of deicing salts has improved the safety of winter weather driving, reducing accident rates by a factor of 8 on two-lane highways and 4.5 on multi-lane highways. The use of salt reduces injuries, property damage, and the severity of accidents during winter storms, thereby reducing costs of accidents (Kuemmel and Hanbali, 1992).

General highway application rates for deicing salt range from less than 1 ton per lane mile ${ }^{2}$ per year to 20 tons per lane mile per year (Transportation Research Board, 1991; Jones and Sroka, 1997). Information on the rate of deicing-salt applications was acquired by compiling a list of the cities nearest to groundwater-sampling locations (table 2) and conducting an informal, qualitative survey of 20 local and State highway superintendents to provide information on the type and amount of deicing chemicals being applied to roads and highways in different parts of the study area. Respondents were asked to describe the number of lane or road miles serviced, and the type and amount of deicing chemicals purchased; application rates in units of tons per road or lane mile were calculated on the basis of that information (table 2).

Most of the highway superintendents reported the use of sodium chloride rock salt. Calcium and magnesium chloride were used in some cases as a wetting agent for rock salt. Application rates per lane mile ranged from less than 1 ton per road mile in Washington State to 74.5 tons per lane mile for a section of Interstate 84 in southeastern New York (Heisig, 2000). Most rates for deicing salt reported by highway officials ranged from 10 to 30 tons per lane mile (table 2). These values are similar to those reported in the literature.

In addition to the effects of application of deicing salts to impervious areas, salt-storage areas have been sites of historical contamination caused by runoff from uncovered salt piles, and infiltration when stored over pervious areas

\footnotetext{
${ }^{2}$ The lane mile is an areal measurement of road surface. The lane mile is one traffic lane (12 ft wide), extending for $1 \mathrm{mi}$ along a road. When applied to highways, this measurement unit includes paved borders and breakdown lanes (Church and others, 1996).
}

(Ostendorf and others, 2006). Many of these historical sites have been improved in recent years through the use of covered salt-storage buildings on impervious substrate. However, high chloride concentrations can persist in groundwater because of the long traveltimes from recharge areas to discharge at a well or surface-water body.

Highway maintenance crews in some parts of the study area are using techniques that enhance the effectiveness of deicing practices. These anti-icing techniques are designed to use salt more effectively by preventing a bond between ice and road surfaces rather than melting ice that has already bonded to the road. These updated practices include the use of road weather-information systems (RWIS) to decide which road deicing practices are appropriate based on weather and road temperature data and the use of salt that has been prewetted, or salt brine, on roadways prior to a predicted storm (Aultman-Hall and others, 2006).

\section{Landfills}

Salt from human consumption or activities is commonly deposited in municipal landfills. These salts typically are from food wastes and other products containing salt, including rubber, metals, and paper products. The estimated 10.3 million tons of salt or salt-bearing products deposited in landfills in 1990 represented 23 percent of reported consumption (Kostick, 1993). This estimated mass indicates that landfills can be source areas for salt constituents. Chloride concentrations are typically high in landfill leachate or in groundwater beneath or downgradient from landfills. For instance, the median chloride concentration in leachate from seven landfills in Illinois was $1,284 \mathrm{mg} / \mathrm{L}$ (Panno and others, 2006). The chloride concentration in leachate in a municipal landfill in Waterbury, Connecticut, was $724 \mathrm{mg} / \mathrm{L}$ in 1997 (Fuss \& O'Neill, Inc., 1997), and $247 \mathrm{mg} / \mathrm{L}$ in shallow groundwater downgradient from the landfill (Mullaney and others, 1999). Landfills are commonly limited in aerial extent and can be areas with low groundwater recharge because of impervious capping material, which limits the release of large volumes of leachate to shallow aquifers or surface-water bodies. However, as with deicing-salt storage areas, landfills can be a longterm source of salt to aquifers and streams as a result of long groundwater traveltimes.

\section{Wastewater and Water Treatment}

Chloride in the environment is conservative (nonreactive), and thus there is little loss when chloride in salts contained in food, beverages, and household cleaning products is discharged to the environment through septic systems and wastewater-treatment facilities. In addition, water softeners used to treat water hardness commonly use salt brine to regenerate the resin in the treatment system with sodium, displacing calcium and magnesium. The remaining brine is then disposed of through the wastewater system, or to a dry well, where it may enter the underlying aquifer and ultimately discharge to a surface-water body. 


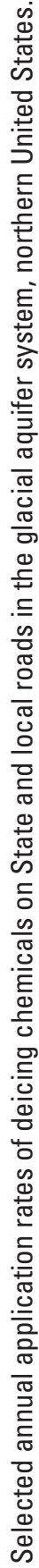
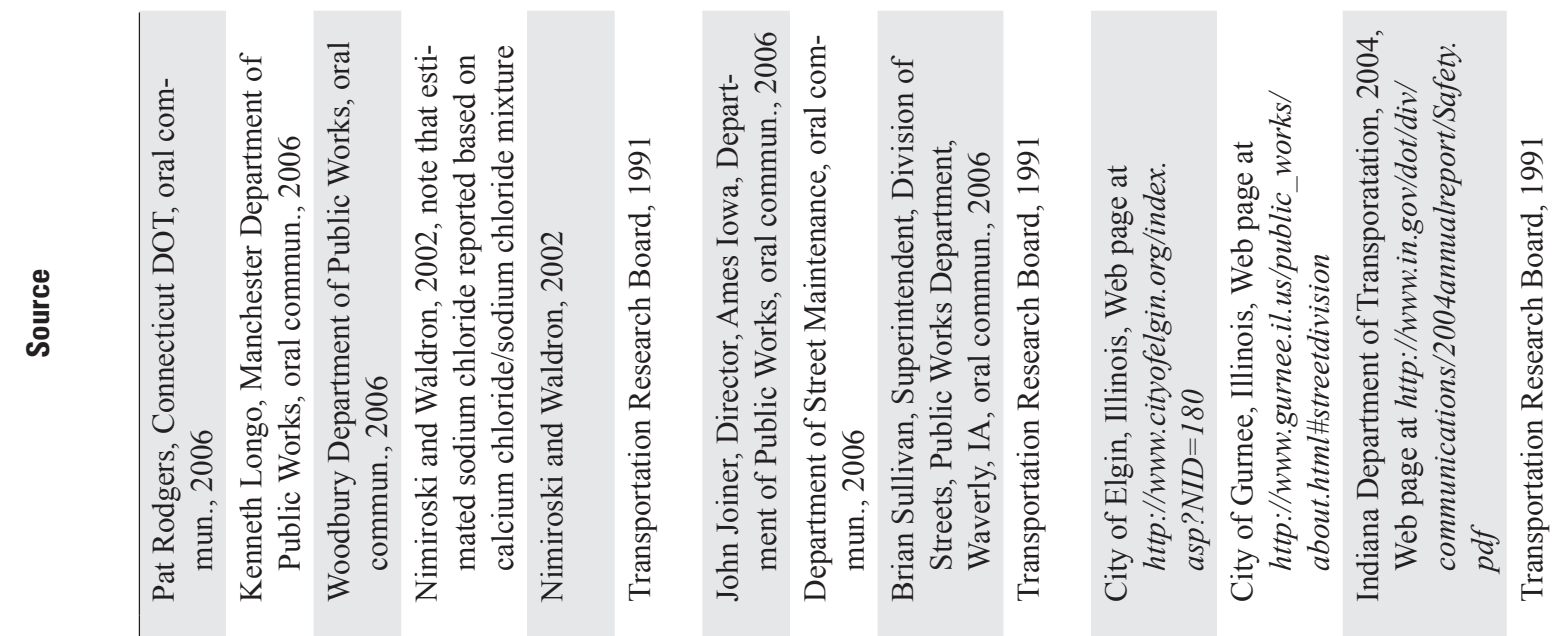

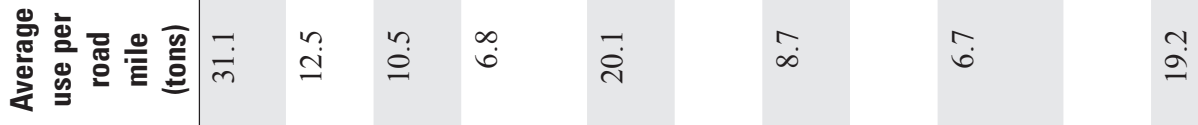

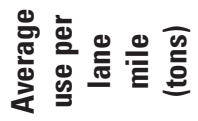

ri $\overrightarrow{0} \quad \infty$

$\stackrel{+}{\circ}$

๑ே:

ลับ

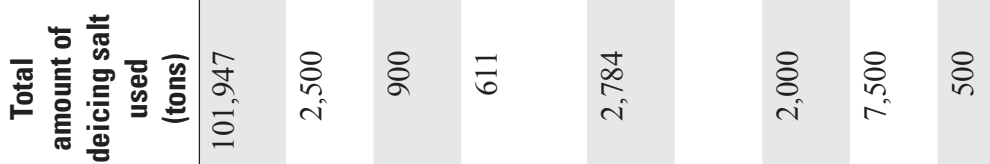

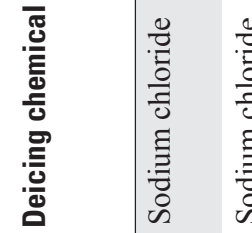

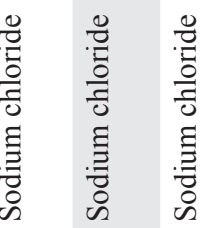

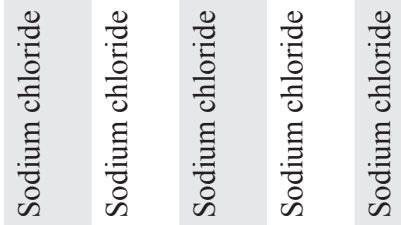

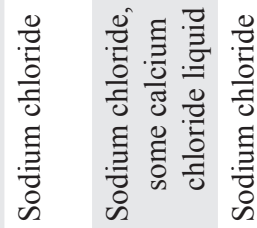

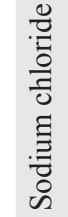

$\frac{n}{m}$

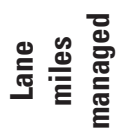

ล

ิㅗำ

8

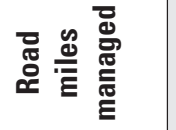

$\stackrel{\sim}{\circ}$

壳

七

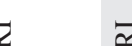

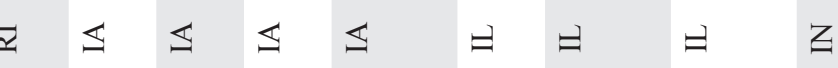

Z

离

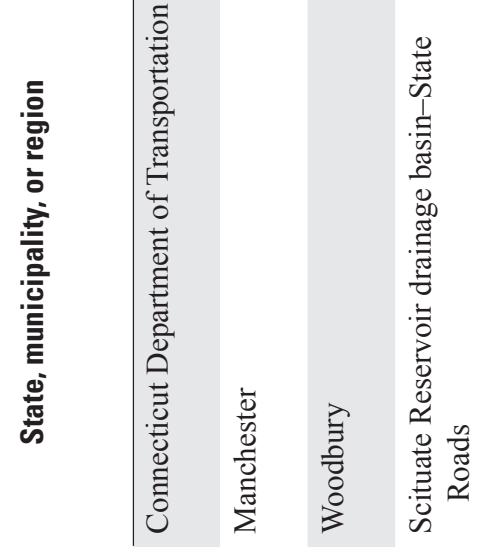

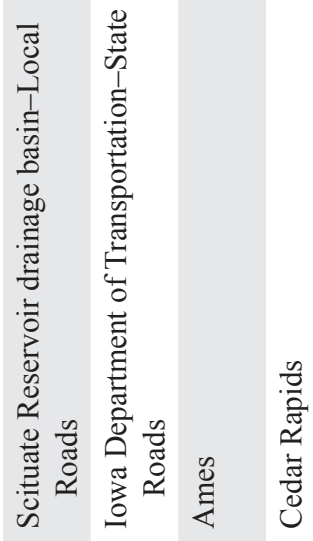

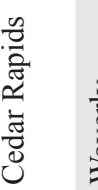

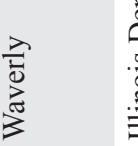

s

年

寒

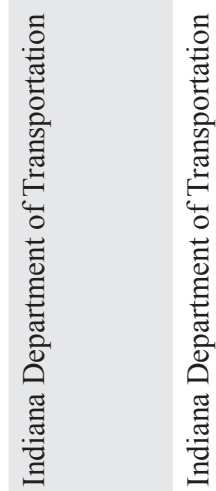




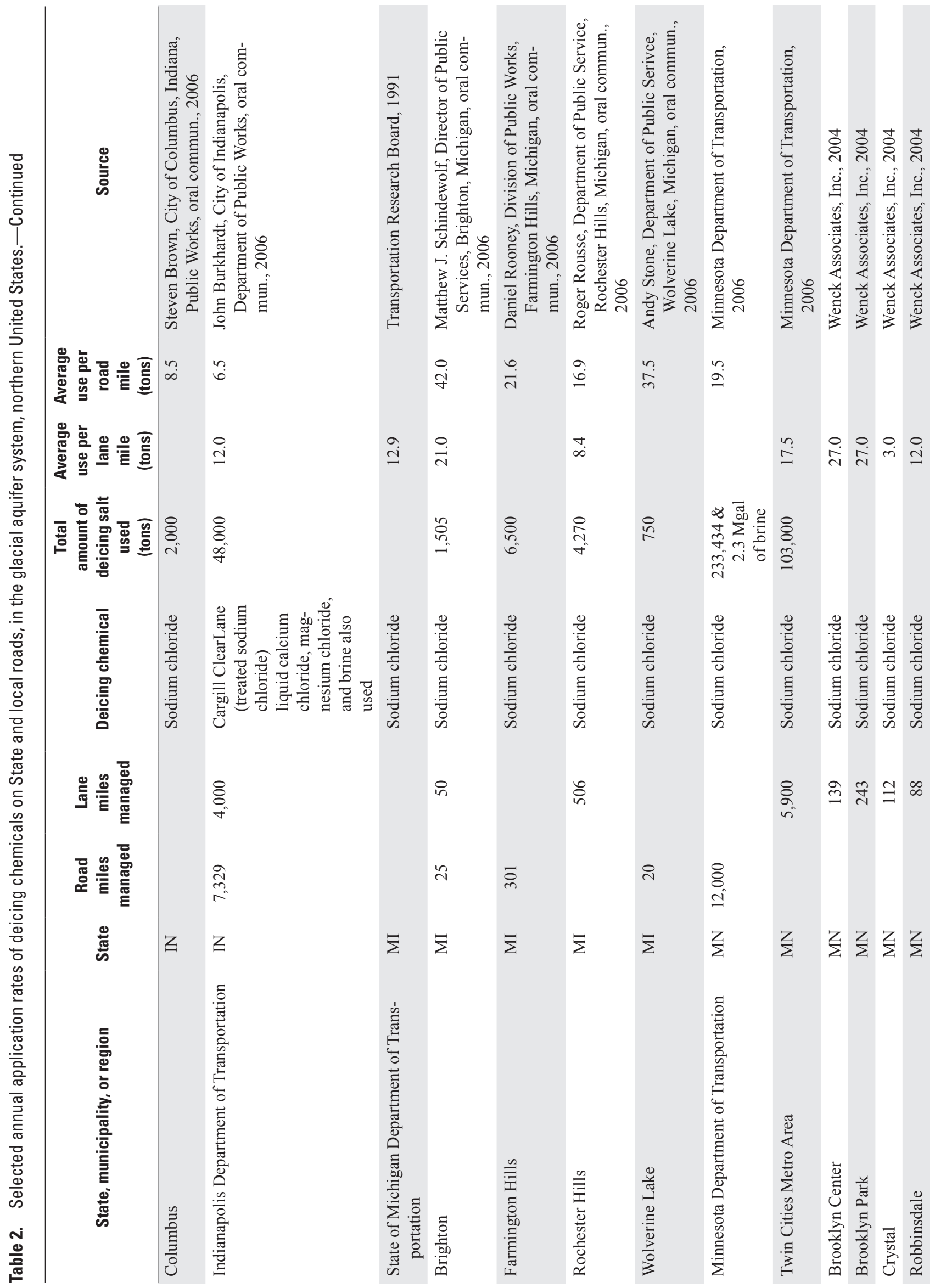




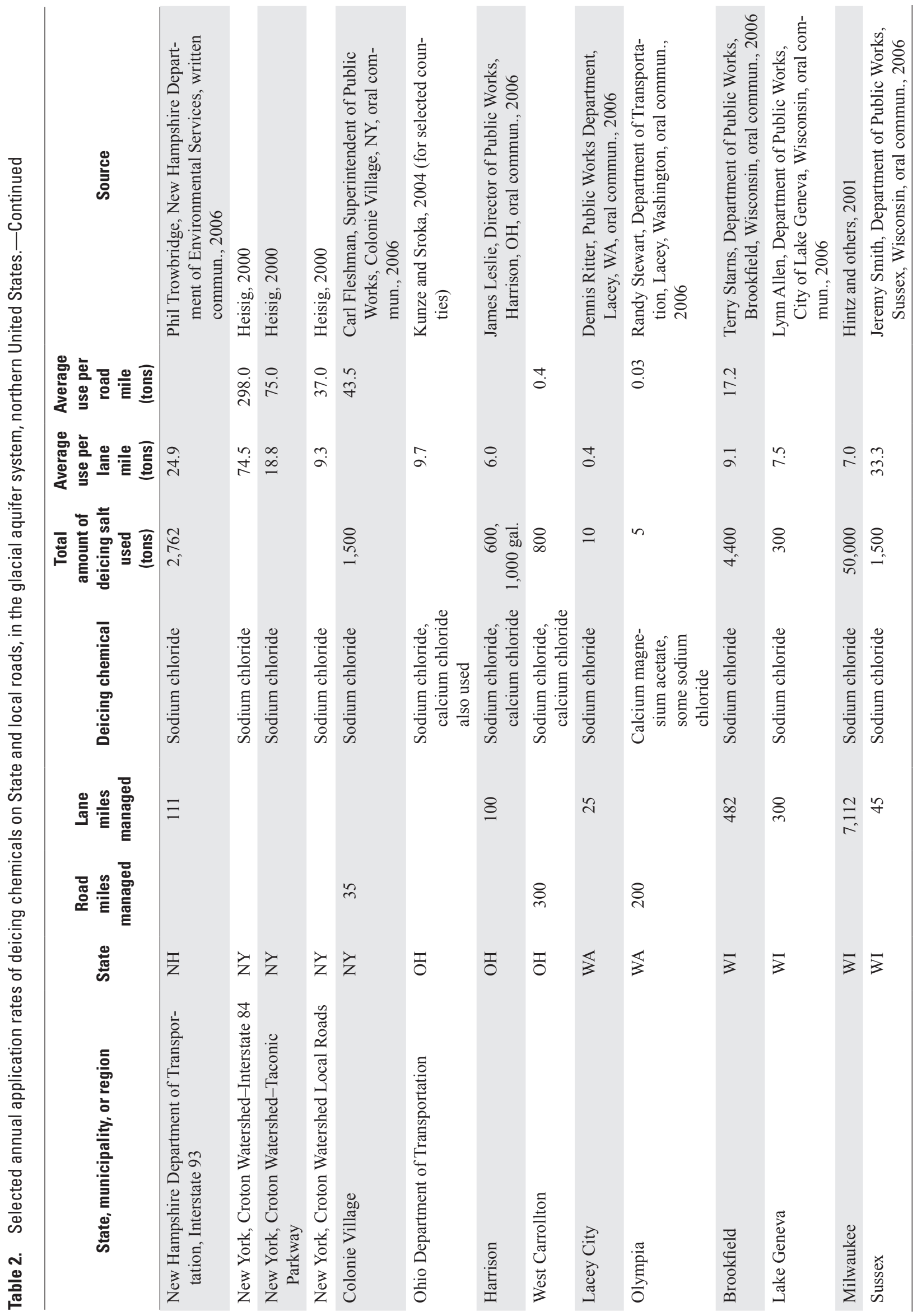


A conservative estimate of the per capita salt consumption and chloride loss from wastewater can be made on the basis of the recommended daily adult sodium intake of $2,300 \mathrm{mg} / \mathrm{d}$. The salt intake associated with $2,300 \mathrm{mg} / \mathrm{d}$ of sodium is $5,847 \mathrm{mg}$, which includes about $3,547 \mathrm{mg}$ of chloride. This indicates that the average person on this diet would consume about $2.1 \mathrm{~kg}(4.7 \mathrm{lbs})$ of salt per year, and release about $1.3 \mathrm{~kg}(2.9 \mathrm{lbs})$ of chloride per year to wastewater discharge.

Water softeners can release considerably larger amounts of chloride to the environment. Discharge of chloride to the environment from water softening is through on-site septic systems, dry wells, or wastewater-treatment facilities. In 2005, salt for water treatment represented 3.1 percent of salt use in the United States (Kostick and others, 2007). Salt use varies in a typical residential water-softener installation, however, because of differences in water softeners, water use, and water hardness.

Water softeners likely are used extensively in the study area for homes with self-supplied domestic wells and in areas with publicly provided surface and groundwater supplies. Moderately hard water is found in most regions of the study area, although soft water predominates in the New England area. Hard and very hard waters are present in central and west central States, including Ohio, Michigan, Illinois, Wisconsin, Minnesota, and North Dakota (Briggs and Ficke, 1977).

\section{Agriculture}

Agricultural use of salt was about 3.5 percent of total use in 2005 (Kostick and others, 2007). Salt is used as an animal feed additive and may be used in other agricultural products such as pesticides and fertilizers. Salt from animal feeds may discharge to surface water and groundwater from feedlots and manure containment areas and from the use of manure as a fertilizer. Panno and others (2006) reported a median chloride concentration of $847 \mathrm{mg} / \mathrm{L}$ from hog and horse waste, and a median concentration of $57 \mathrm{mg} / \mathrm{L}$ in water samples from wells affected by animal waste in Illinois.

Agricultural fertilizers can be a source of chloride to receiving waters because the potassium in most fertilizers is in the form of potassium chloride. Other sources of chloride include the concentration and dissolution of salts resulting from irrigation from deep groundwater sources.

\section{Methods of Data Analysis}

NAWQA Program data from 1991 to 2004 from wells in the glacial aquifer system and from streams draining areas underlain by the glacial aquifer system were analyzed for this study. Ancillary information was synthesized from data compiled for each surface-water-quality station that was sampled in the NAWQA Program. Many surface-water monitoring stations had additional water-quality data collected by the USGS for State water-quality monitoring networks.
Data analysis included graphical plotting of concentrations of water-quality constituents, multiple-comparison tests, and statistical analyses of the relations between ancillary variables and chloride concentrations and yields in surface water. A multiple linear regression model (LOADEST) (Runkel and others, 2004) was used to analyze chloride loads in water from 95 surface-water monitoring stations.

\section{Compilation of Environmental Data}

Groundwater-quality and surface-water-quality data were synthesized from data collected from 1991 to 2004 in the study basins shown in figure 2 . Groundwater-quality data were compiled from a national database established for all groundwater samples collected for the NAWQA Program in the glacial aquifer system study area. The groundwater data collected represent two different networks: (1) shallow monitoring wells in forested, agricultural, or urban land (land-use studies), and (2) drinking-water supply wells tapping glacial deposits (major aquifer studies) (Rosen and Lapham, 2008).

In land-use studies, data were collected from installed observation wells and selected existing observation wells to assess the quality of recently recharged shallow groundwater beneath different land-use settings (Gilliom and others, 1995). For this investigation, data from 797 wells from land-use studies (fig. 5) representing forested, agricultural, and urban areas were compiled for statistical analysis. Samples generally were collected only once from these wells.

In major aquifer studies conducted by the NAWQA Program, data were collected from 94 public and 438 private drinking-water supply wells in the glacial aquifer system (drinking-water network, fig. 5). These wells are typically deeper than the wells sampled for land-use studies and may integrate recharge from several land uses.

Water-quality data from 100 surface-water monitoring stations (Appendix 1) draining basins dominated by forested, agricultural, or urban land were selected for analysis (fig. 5). The contributing areas of these basins average $286 \mathrm{mi}^{2}$, and the median is $88 \mathrm{mi}^{2}$; of these basins, at least 31 contain major point-source wastewater discharges listed in the Permit Compliance System (PCS) database (U.S. Environmental Protection Agency, 2007). Surface-water monitoring stations had at least 20 samples collected over at least a 3-year period from 1991 to 2004. Samples generally were collected monthly for 3 to 13 years. Nineteen of the stations selected have longterm-flow and water-quality records that began in the 1960 s to 1980 s.

\section{Multiple Comparison Testing}

Multiple comparison tests were done by using S-PLUS 7 software (Insightful Corporation, 2005) to determine if populations of $\log$ base 10 chloride and sodium concentrations and chloride:bromide ratios by mass $(\mathrm{Cl}: \mathrm{Br})$ in groundwater were significantly different by adjacent land use or well type. 


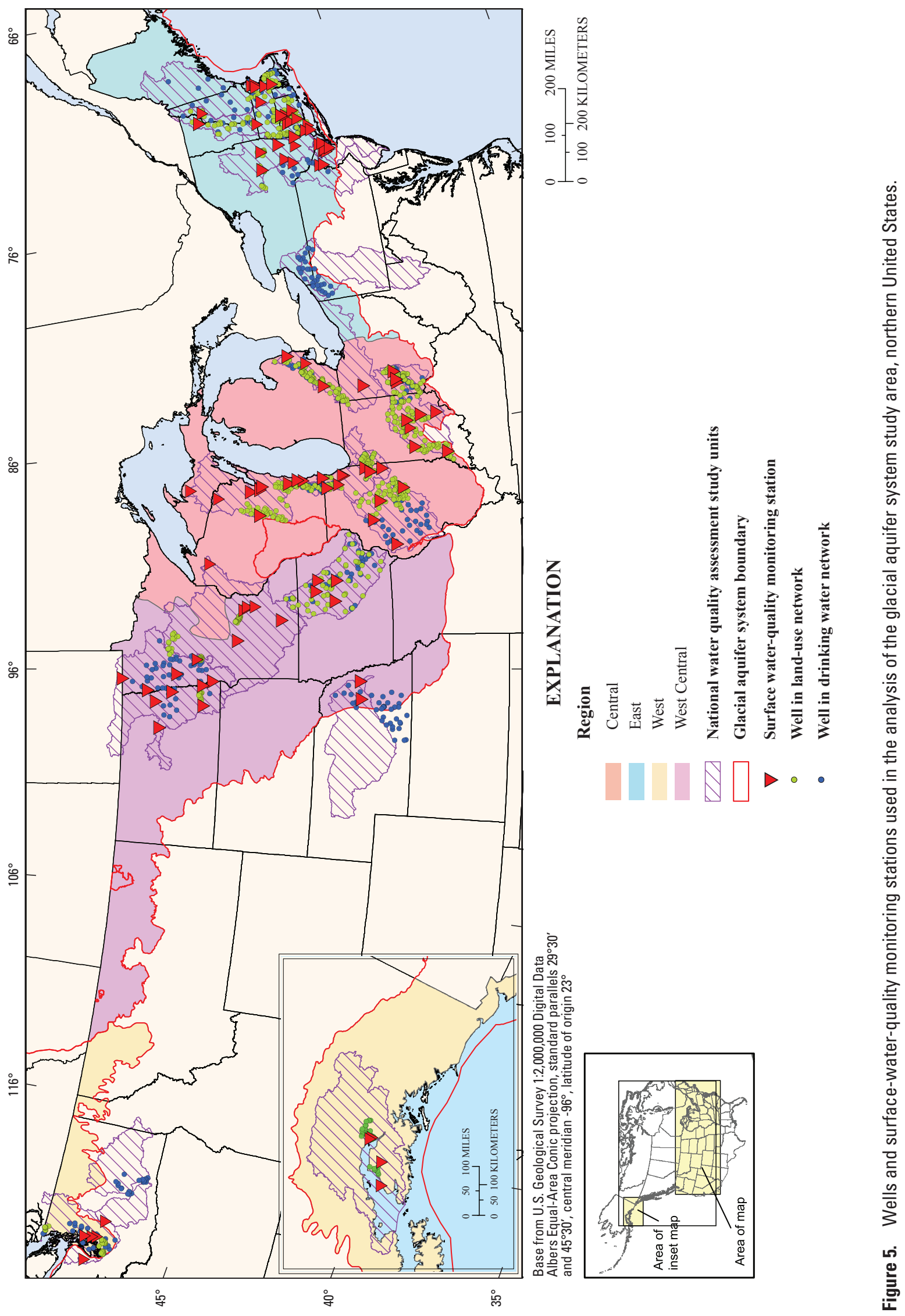


This analysis also was used with maximum measured chloride concentrations and yields from samples collected in streams. A one-way analysis of variance (ANOVA) test was used to determine if the null hypothesis was rejected; the null hypothesis states that the means of all groups were not significantly different. If the null hypothesis was rejected, a Tukey's test for pairwise comparisons was done (Helsel and Hirsch, 2002).

\section{Multiple Linear Regression Modeling}

Multiple linear regression models were developed to describe maximum measured chloride concentrations (1991-2004) and mean chloride yield (1991-2003) for samples collected from surface-water monitoring stations. Explanatory variables that were evaluated for use in the models included land-use/land-cover characteristics, population density, road density, hydrologic and climatic variables, and wastewater discharges (table 3). Variables were selected on the basis of plausibility, statistical significance, and the distribution of residuals.

Data on land-use and land-cover characteristics were determined from LANDSAT Thematic Mapper (TM) images created for the National Land Cover Dataset (NLCD) (Vogelmann and others, 1998). The version of the NLCD (NLCDe) used was enhanced as described by Nakagaki and Wolock (2005).

Road density was computed as the length of all roads in a basin divided by basin area (Curtis Price, U.S. Geological Survey, written commun., 2006). Road density by category was compiled for surface-water basins from the digital Streetmap layer of the Tele Atlas North America (ESRI, Inc., 2006).

Potential evapotranspiration data for each surface-water site were developed through the use of the Parameter-elevation Regressions on Independent Slopes Model (PRISM) with the methodology described by Daly and others (1994).

Hydrologic variables were compiled from a national application of the TOPMODEL rainfall-runoff model (Wolock, 1993). Stream base-flow index was estimated by using data developed by Wolock (2003).

\section{Estimation of Chloride Loads}

Chloride loads in streams were estimated for 95 basins (those with sufficient data for load estimation) - 21, 44, and 30 representing forested, agricultural, and urban as the dominant land use, respectively (Appendix 1). Loads were estimated for water years with available data from 1992-2003. Nineteen stations had data collected earlier than 1992, and chloride loads at these sites were plotted against time to identify obvious long-term trends.

Loads were estimated by using a multiple linear regression model included in the computer program LOADEST (Runkel and others, 2004). Given a time series of streamflow, additional data variables, and constituent concentration, LOADEST assists the user in developing a regression model for the estimation of constituent load. Explanatory variables in the regression model include various functions of streamflow, decimal time, and additional user-specified data variables. The formulated regression model then is used to estimate loads over a user-specified time interval. Mean load estimates, standard errors, and 95-percent confidence intervals are developed on an annual basis. The calibration and estimation procedures in LOADEST are based on three statistical estimation methods. The first two methods, Adjusted Maximum Likelihood Estimation (AMLE) and Maximum Likelihood Estimation (MLE), are appropriate when the calibration model errors (residuals) are normally distributed. Of the two, AMLE is the method of choice when the calibration data set (time series of streamflow, additional data variables, and concentration) contains censored data. The third method, Least Absolute Deviation (LAD), is an alternative to MLE when the residuals are not normally distributed (Runkel and others, 2004). Load estimates for selected urban basins were plotted to demonstrate visible trends with time by using a LOWESS smooth (Helsel and Hirsch, 2002).

\section{Chloride in Groundwater and Surface Water}

The concentrations of chloride and sodium in water from wells in the land-use studies network and major aquifer studies network were compared first by land use and well type and then to applicable drinking-water standards. Sources of chloride were evaluated on the basis of $\mathrm{Cl}$ : $\mathrm{Br}$ plotted against chloride and compared to binary mixing curves estimated for different sources.

Surface-water-quality data were compared with the recommended criteria for chloride concentrations to protect aquatic life and to determine the months when the recommended criteria concentrations commonly were exceeded. A multiple linear regression model was developed to describe the variability of the natural log of the maximum measured chloride concentration at all surface-water monitoring stations. These maximum measured concentrations of chloride were compared with concentrations of chloride in base-flow samples from each station to determine if base-flow concentrations could be used to predict which stations would have chloride concentrations greater than recommended aquatic criteria. Lastly, the loads and yields of chloride from 95 monitoring stations were computed, and yields were compared by dominant land use. A multiple linear regression model was used to describe the variability of the natural log of chloride yield. Selected stations with long-term data were used to show examples of apparent trends in chloride loads with time. 
Table 3. Watershed characteristics evaluated in a regression analysis of maximum measured chloride concentrations.

[NLCDe, National Land Cover Dataset, Vogelmann and others, 1998, enhanced as described by Nakagaki and Wolock (2005); km, kilometer; km², square kilometer; cm, centimeter; mi, mile; mi $^{2}$, square mile; PRISM, Parameter-elevation Regressions on Independent Slopes Model; PCS, permit compliance system]

\section{Land use, land cover (Vogelmann and others, 1998), population and road density}

Percent of basin composed of low intensity residential, NLCDe

Percent basin composed of high intensity residential, NLCDe

Percent basin composed of commercial/industrial/transportation, NLCDe

Percent of basin composed of orchards/vineyards/other, NLCDe

Percent basin composed of pasture/hay, NLCDe

Percent basin composed of row crops, NLCDe

Percent basin composed of small grains, NLCDe

Percent basin composed of fallow, NLCDe

Population density 2000, in people/ $\mathrm{km}^{2}$ (ESRI, 2006)

Road density in $\mathrm{km} / \mathrm{km}^{2}$ (Curtis Price, U.S. Geological Survey, written commun., 2006)

\begin{tabular}{|c|}
\hline Road density by type (ESRI, Inc., 2006) \\
\hline Major highway connector density, in $\mathrm{mi} / \mathrm{mi}^{2}$ \\
\hline Major road density, in $\mathrm{mi} / \mathrm{mi}^{2}$ \\
\hline Local road density, in mi/mi² \\
\hline Percent of basin streamflow contributed by Dunne overland flow (estimated by means of TOPMODEL (Wolock, 1993) hydrologic model) \\
\hline Percent of basin streamflow contributed by Horton overland flow (estimated by means of TOPMODEL (Wolock, 1993) hydrologic model) \\
\hline Mean subsurface contact time in days (estimated by means of TOPMODEL (Wolock, 1993) hydrologic model) \\
\hline Base-flow index \\
\hline Mean potential evapotranspiration in cm (PRISM) [Daly and others, 1994] \\
\hline
\end{tabular}

\section{Wastewater discharges}

Number of major discharges upstream of monitoring site, PCS database (U.S. Environmental Protection Agency, 2007)

Number of minor discharges upstream of monitoring site, PCS database (U.S. Environmental Protection Agency, 2007)

\section{Groundwater}

Groundwater samples collected from wells in the land-use studies contained different distributions of chloride depending on the dominant land use (fig. 6). The largest median concentration of chloride was in samples from urban land-use wells (46 mg/L) and was about 16 times larger than the median concentration in samples from forested land-use wells $(2.9 \mathrm{mg} / \mathrm{L})$. The median concentration in water samples from agricultural land-use wells $(12 \mathrm{mg} / \mathrm{L})$ was about four times larger than in samples from forested land-use wells. The median concentration of chloride in drinking-water supply wells was $26 \mathrm{mg} / \mathrm{L}$ in public-supply wells and $12 \mathrm{mg} / \mathrm{L}$ in private domestic wells (fig. 6). The results of a one-way ANOVA indicated that the means of the populations of log base- 10 transformed chloride data were significantly different. A Tukey's test indicated that only the agricultural land-use wells and the private drinking-water wells were not significantly different (fig. 6).

Chloride concentrations in groundwater were greater than the SMCL of $250 \mathrm{mg} / \mathrm{L}$ for drinking water (U.S. Environmental Protection Agency, 1992) in samples from 20 of 797 land-use wells (2.5 percent); 17 were urban land-use wells and 3 were agricultural land-use wells. Chloride concentrations were greater than $250 \mathrm{mg} / \mathrm{L}$ in 10 of 532 drinking-water wells (1.7 percent); 9 were private domestic wells and 1 was a public-supply well. Groundwater with concentrations of chloride in excess of $230 \mathrm{mg} / \mathrm{L}$ that discharges to surface water may cause toxic effects to aquatic life on the basis of the recommended criteria established by U.S. Environmental Protection Agency (1988). 


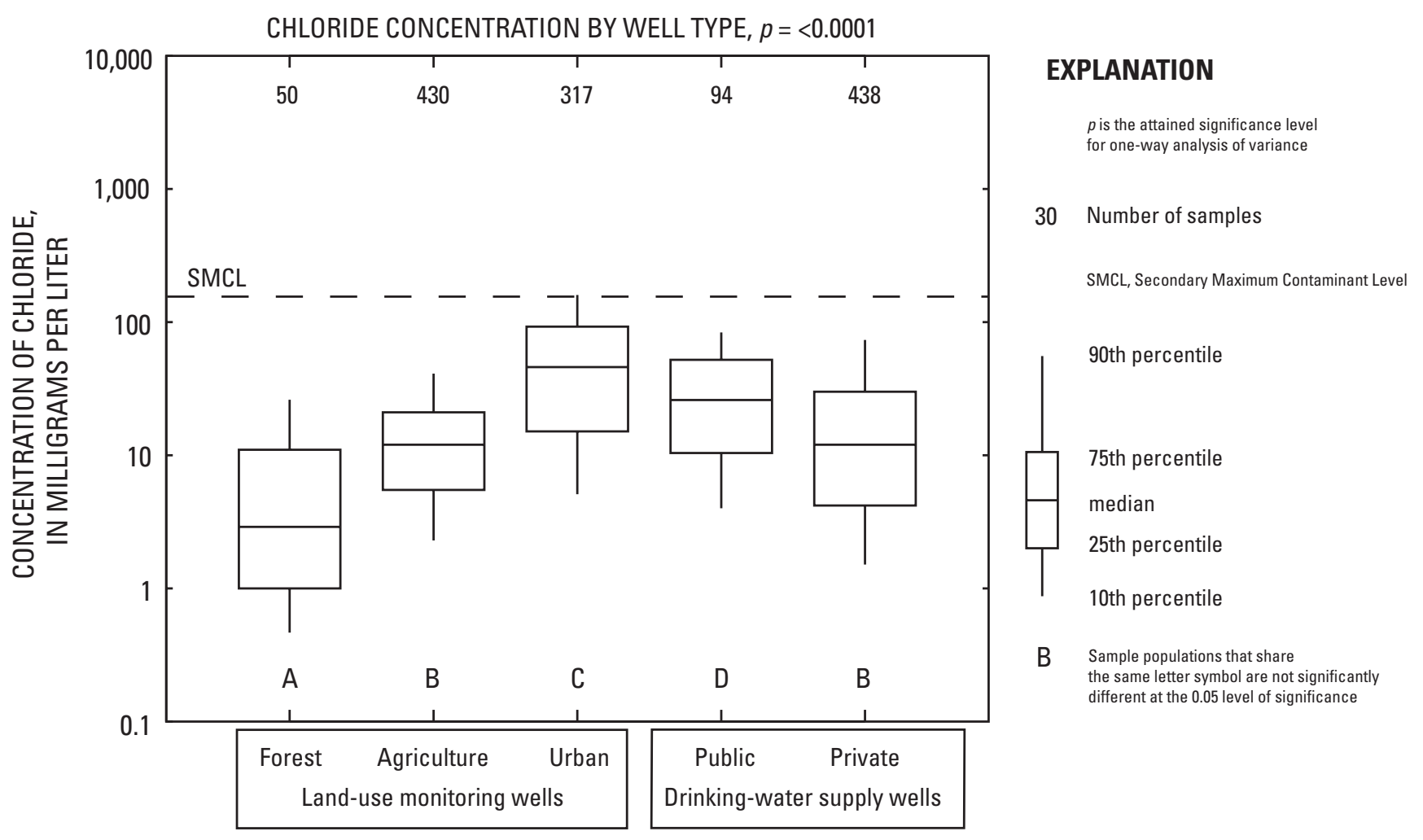

Figure 6. Distribution of chloride concentrations in samples from shallow monitoring wells in forested, agricultural, and urban areas and in drinking-water supply wells in the glacial aquifer system, northern United States, 1991-2003.

Because sodium in drinking water is considered a human health issue, concentrations of sodium were also summarized for groundwater sites in this study. The distribution of sodium concentrations (in samples from 1,332 sites) was similar to that of chloride in the land-use wells. The largest median concentration of sodium was in samples from urban-land-use wells $(26 \mathrm{mg} / \mathrm{L})$ and was more than six times larger than the median concentration of sodium $(4.1 \mathrm{mg} / \mathrm{L})$ in water samples from forested-land-use wells. The median sodium concentration in water samples from agricultural-land-use wells (6.3 $\mathrm{mg} / \mathrm{L}$ ) was larger than the median sodium concentrations in the forested-land-use wells (fig. 7). The median sodium concentration was $19 \mathrm{mg} / \mathrm{L}$ in public-supply wells and $12 \mathrm{mg} / \mathrm{L}$ in private domestic wells. The only Federal drinking-water standard for sodium is an unenforceable Drinking Water Advisory of $20 \mathrm{mg} / \mathrm{L}$ for individuals on a 500 milligram per day $(\mathrm{mg} / \mathrm{d})$, low-sodium diet (U.S. Environmental Protection Agency, 2004). Water in the majority of urban land-use wells (57.1 percent) had concentrations of sodium equal to or greater than $20 \mathrm{mg} / \mathrm{L}$, followed by agricultural land-use wells (16.7 percent) and forested land-use wells ( 8.0 percent). The concentration of sodium was equal to or larger than $20 \mathrm{mg} / \mathrm{L}$ in samples from 46.8 percent of the public-supply wells and 33.9 percent of the domestic wells.

\section{Sources of Chloride in Groundwater}

Chloride:bromide ratios $(\mathrm{Cl}: \mathrm{Br})$ have been used by several researchers to identify the sources of chloride in groundwater (Davis and others, 1998; Thomas, 2000; Jagucki and Darner, 2001; Panno and others 2006). The method is based on understanding the $\mathrm{Cl}: \mathrm{Br}$ and chloride concentrations of different chloride sources, and the resulting $\mathrm{Cl}: \mathrm{Br}$ and chloride concentrations when these sources are mixed.

Groundwater samples collected from a network of forested land-use wells had the lowest median $\mathrm{Cl}: \mathrm{Br}$ ratio (by mass) (148). Samples collected from wells in the urban land-use study had the highest median $\mathrm{Cl}: \mathrm{Br}$ (879), followed by the samples from wells in the agricultural land-use well study (283) (fig. 8). The median $\mathrm{Cl}: \mathrm{Br}$ of water samples from the private drinking-water wells (193) was not significantly different from the median for forested land-use wells, and the median $\mathrm{Cl}$ :Br of samples from the public drinking-water-supply wells (673) was not significantly different from the ratio for the urban land-use wells (fig. 8).

Mixing curves (fig. 9A) were developed to represent binary mixtures of halite, sewage or animal waste, potassium chloride fertilizers, landfill leachate, basin brines, and seawater sources of chloride on the basis of data and studies listed in table 4 . Binary mixing-curve lines were determined by using 


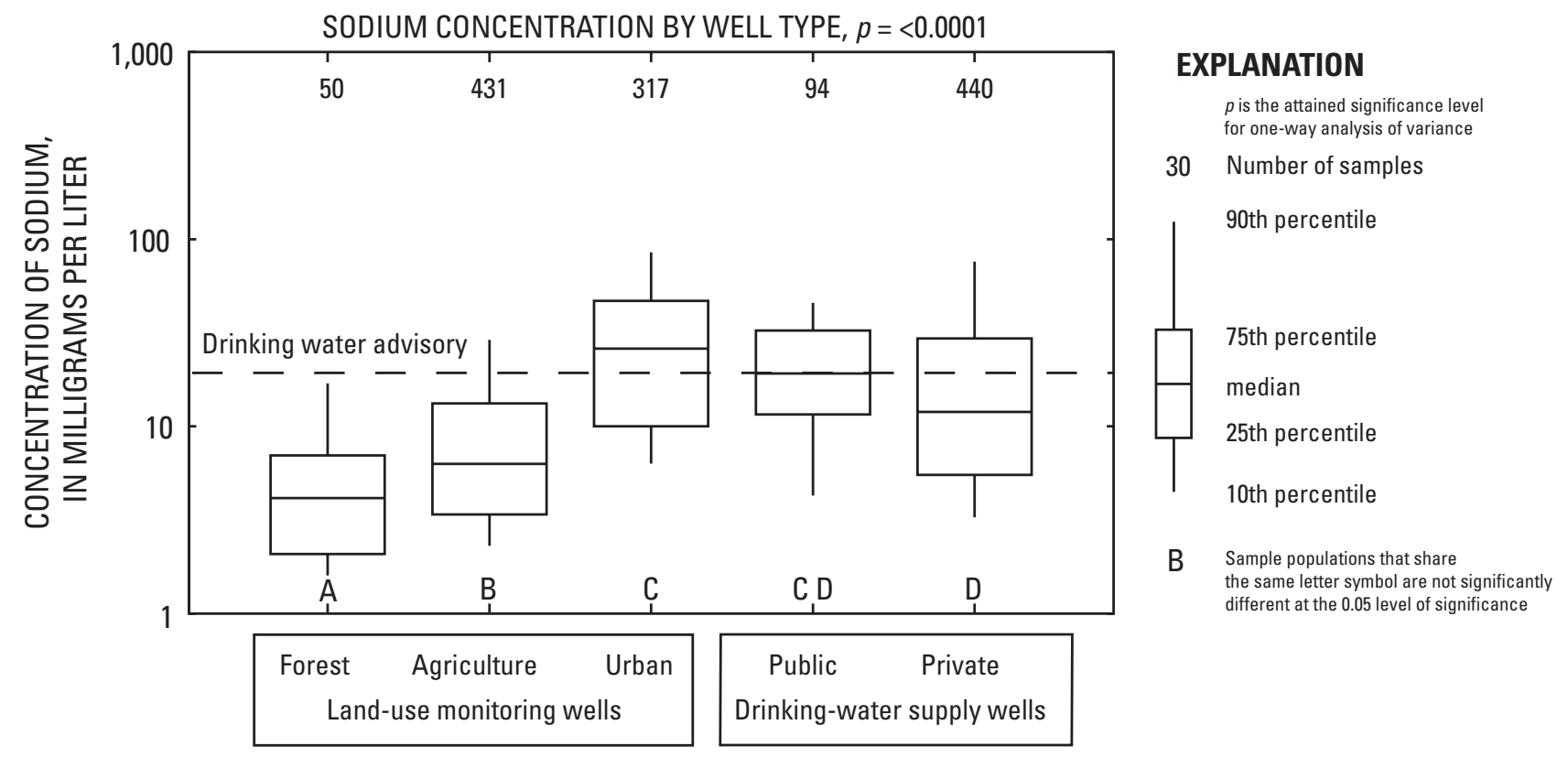

Figure 7. Distribution of sodium concentrations in samples from shallow monitoring wells in forested, agricultural, and urban areas and in drinking-water supply wells in the glacial aquifer system, northern United States, 1991-2003.

mixing equations described by Jagucki and Darner (2001). Data from the land-use wells were plotted with the binarymixing curves to evaluate if any of samples were representative of end members or simple mixtures (figs. 9B-D).

Points representing groundwater samples that do not fall on any of the binary mixing lines reflect the reality that there may be more than two sources of chloride, and the actual mixtures in groundwater samples are not likely mixtures of fullstrength end members, but have been diluted with additional water. The effect of dilution of a concentrated end member with precipitation or dilute groundwater will be to retain the $\mathrm{Cl}: \mathrm{Br}$, but reduce the chloride concentration. An example of this would be a mixture containing chloride from sewage/ animal waste and halite. The binary mixing curves 5 and 6 on figures $9 \mathrm{~A}-\mathrm{D}$ are based on the assumption that mixtures can contain different proportions of the full-strength end members. The halite end members were assumed to have a chloride concentration of 10,000-20,000 mg/L; higher concentrations are possible based on the solubility of halite. In reality, deicing salt is likely to be diluted with precipitation before recharging the groundwater, and septic-system waste may also be diluted with precipitation or dilute groundwater before moving downgradient. Therefore, most mixtures are not likely equivalent to binary mixtures, unless samples are collected very close to the source of the chloride.

The samples from the forested-land-use wells generally had low $\mathrm{Cl}: \mathrm{Br}$ and low concentrations of chloride; however, the positions of the plotted points for nine samples (fig. 9B) indicated human influence from halite or sewage and animal waste. Samples from the agricultural-land-use wells were not dominated by any one source of chloride (fig. 9C), although there was a large concentration of points around mixtures of dilute groundwater and potassium chloride or sewage and animal waste. Sources of chloride in agricultural areas could include deicing salt; salt used in animal feeds, fertilizer, and water softeners; salt in animal waste; and the use of deep groundwater (containing brines) for irrigation. Points for chloride concentrations above $100 \mathrm{mg} / \mathrm{L}$ in samples from agricultural-land-use wells plotted near the binary mixing curves (lines) for dilute groundwater and (1) halite, or (2) sewage or animal waste mixed with halite, or (3) dilute groundwater mixed with basin brines, or (4) landfill leachate.

Points representing samples from the urban-land-use wells plotted along or between the mixing lines for dilute groundwater/halite, or dilute groundwater/sewage or animal waste, and dilute groundwater and potassium chloride fertilizer (fig. 9D). Many samples had a $\mathrm{Cl}: \mathrm{Br}$ of 1,000 or higher and chloride concentrations greater than $100 \mathrm{mg} / \mathrm{L}$. This analysis shows that, as in the agricultural areas, there are mixed sources of anthropogenic inputs of chloride to groundwater. Samples with a $\mathrm{Cl}: \mathrm{Br}$ greater than 1,000 and chloride concentrations greater than $100 \mathrm{mg} / \mathrm{L}$ are likely to be dominated by halite inputs from deicing or water softeners.

Points representing samples from drinking-water supply wells initially were plotted with the binary mixing curves that were used in figures 9A-D; however, there was a wide 


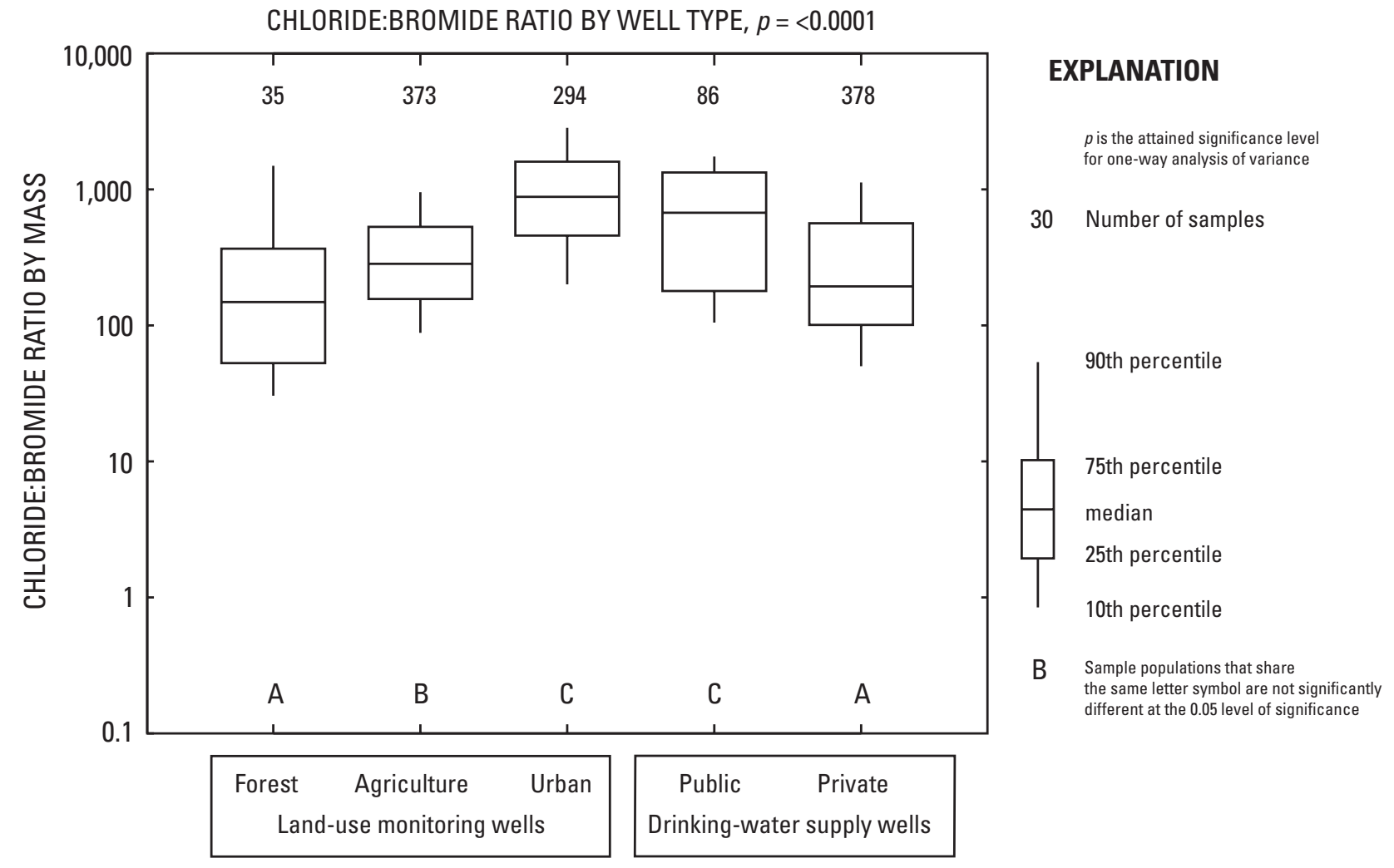

Figure 8. Distribution of chloride:bromide ratios (by mass) in samples from shallow monitoring wells in forested, agricultural, and urban areas and in drinking-water supply wells in the glacial aquifer system, northern United States, 1991-2003.

scattering of points around the binary mixing lines. There were, however, some statistically significant differences in the $\mathrm{Cl}: \mathrm{Br}$ by supply-well type (fig. 8 ) and by the geographic region (fig. 10). Public drinking-water supply wells had a significantly higher $\mathrm{Cl}$ :Br than private drinking-water wells, indicating that water quality in these public drinking-water supply wells is influenced by human activities, primarily deicing, water softening, and sewage/animal waste.

$\mathrm{The} \mathrm{Cl}: \mathrm{Br}$ in samples from the private drinking-water supply wells was were not significantly different from ratios in samples from the forested land-use wells (fig. 8); however, concentrations of chloride were significantly higher in the private drinking-water supply wells than in samples from the forested land-use wells (fig. 6).

Samples from drinking-water supply wells in the east had significantly higher $\mathrm{Cl}: \mathrm{Br}$ than samples from other regions in the glacial aquifer system (fig. 10). Samples from the westcentral and west parts of the glacial aquifer system had the lowest $\mathrm{Cl}: \mathrm{Br}$ (fig. 10). The $\mathrm{Cl}: \mathrm{Br}$ in 65 percent of the samples from the east and 43 percent of the samples from the central parts of the glacial aquifer system were greater than 460 (table 4, minimum value for sewage and animal waste), indicating the influence of chloride from deicing salt, water-softening salt, and sewage and animal waste (fig. 10).

\section{Surface Water}

Surface-water-quality data from monitoring sites on 100 streams or rivers that were sampled 10 or more times for chloride from 1991 to 2004 were analyzed to make comparisons of chloride concentration to basinwide land use. Samples generally were collected monthly for 3 to 13 years. Some sites that were part of State networks had many more years of chloride data. Multiple linear regression models were developed to describe the distribution of maximum measured chloride concentrations and chloride yields for samples collected from 1991 to 2004 in forested, agricultural, and urban basins. Chloride yields were compared among forested, agricultural, and urban basins.

To evaluate the potential for chloride concentrations to be greater than the USEPA recommended aquatic life criteria described below for chloride (U.S. Environmental Protection Agency, 1988), the maximum measured concentrations (samples collected from 1991 to 2004) were compared by land use (fig. 11). The recommended chronic criterion for aquatic life is a 4-day average of $230 \mathrm{mg} / \mathrm{L}$ with a recurrence interval of once every 3 years (U.S. Environmental Protection Agency, 1988). Samples from 13 sites with urban land use and 2 sites with agricultural land use had chloride values that were greater 
than the chronic concentration value at least once (table 5). Sampling frequency was insufficient to determine whether the 4-day average would have been greater than $230 \mathrm{mg} / \mathrm{L}$ with a recurrence interval of less than once every 3 years. Six of the sites had chloride concentrations greater than $230 \mathrm{mg} / \mathrm{L}$ in 10 percent or more of the samples collected. Concentrations in samples from three sites were greater than the recommended acute aquatic criterion concentration for chloride of $860 \mathrm{mg} / \mathrm{L}$ (U.S. Environmental Protection Agency, 1988). This criterion relates to a 1-hour average concentration with a recurrence interval of less than once every 3 years.

Samples with concentrations of chloride greater than $230 \mathrm{mg} / \mathrm{L}$ generally were collected during the winter and spring months, primarily November-April, indicating a possible relation with winter deicing activity (table 5). Concentrations above the recommended criteria may occur during a rain or freezing rain event following the application of deicing chemicals, or when daytime temperatures rise high enough to melt roadside and parking-lot snow and ice (fig. 12). Samples with chloride concentrations above the recommended aquatic criteria in late spring and summer may be explained by the discharge of groundwater containing high concentrations of chloride (for example, Shingle Creek, station 05288705 and Lincoln Creek, station 040869415; table 5) or could be related to wastewater discharges with high chloride during a low-flow period, as in the case of two monitoring stations in Illinois $(05531500,05532000)$ identified in table 5 (CH2M HILL Inc., 2003).

Concentrations of chloride considered to represent base-flow samples collected from 1991-2004 were selected from the data by using the sample with the lowest river discharge at each site. Samples collected during base-flow periods are presumed to represent the quality of groundwater, except for basins with major wastewater discharges. The median concentration of chloride was $81 \mathrm{mg} / \mathrm{L}$ in base-flow samples from urban basins, $21 \mathrm{mg} / \mathrm{L}$ from agricultural basins, and $3.5 \mathrm{mg} / \mathrm{L}$ from forested basins. Chloride concentrations for the selected base-flow samples were plotted against the maximum measured chloride concentrations to determine whether there was a relation (fig. 13). Maximum measured chloride concentrations were greater than $230 \mathrm{mg} / \mathrm{L}$ in samples from sites at which base-flow chloride concentrations were greater than about $75-90 \mathrm{mg} / \mathrm{L}$. This result suggests that baseflow concentrations can be used to predict which streams may have concentrations larger than the USEPA recommended chronic criteria for chloride. Streams with elevated concentrations of chloride in base flow may be more likely to exceed the recommended criteria during the winter months, because the chloride concentrations are high at the beginning of snowmelt events that contribute stormwater discharge containing concentrated chloride. Therefore, the loads in base flow from groundwater discharge and wastewater discharge are an important consideration in basins with chloride concentrations larger than $230 \mathrm{mg} / \mathrm{L}$.

\section{Relation of Maximum Chloride Concentration to Explanatory Variables}

A multiple linear regression model was developed to describe the variability of the natural log of maximum measured chloride concentrations. The regression analysis was performed on chloride data from 83 of the 100 stations previously described. This subset was used because data for some of the explanatory variables (table 3 ) were unavailable for some stations. The data set included 15 forested basins, 41 agricultural basins, and 27 urban basins. Three significant variables - major road density, potential evapotranspiration, and the percentage of the annual streamflow from saturated overland flow (Dunne overland flow), (table 6) — explained 66 percent of the variability in the natural log of the maximum measured chloride concentration. Model residuals were approximately normally distributed with a constant variance (fig. 14).

Basins with greater density of major roads had higher maximum chloride concentrations. This variable indicates a likely relation with areas receiving deicing salts, but road densities also are usually correlated with overall urbanization and population density, indicating the possibility for multiple sources of chloride, as described in earlier sections of this report.

Basins with higher average potential evapotranspiration generally had higher maximum concentrations of chloride. The significance of this variable may be explained as follows: sites with low evapotranspiration are more likely to have more groundwater recharge (Granato and others, 1995), and areas with high potential evapotranspiration may be more likely to concentrate salts in basin recharge and runoff.

The variable "Dunne overland flow" was significant and had a negative sign. This variable is also known as "saturation overland flow" and was described by Dunne and Black (1970). The negative sign indicates that basins with the most annual saturated overland flow had lower maximum chloride concentrations, because with more overland runoff, there is a greater potential for dilution of salts.

\section{Loads and Yields of Chloride from Forested, Agricultural, and Urban Basins}

Chloride loads were estimated for 20 forested, 44 agricultural, and 31 urban basins from 1991 to 2003. The average load was determined from the LOADEST results for the number of years of available data within the study time period. Loads were normalized by drainage area and converted to yields in tons of chloride per square mile. The median yield was 6.4 tons $/ \mathrm{mi}^{2}$ from the forested basins, 15.4 tons $/ \mathrm{mi}^{2}$ from the agricultural basins, and 88 tons $/ \mathrm{mi}^{2}$ from the urban basins (fig. 15). 


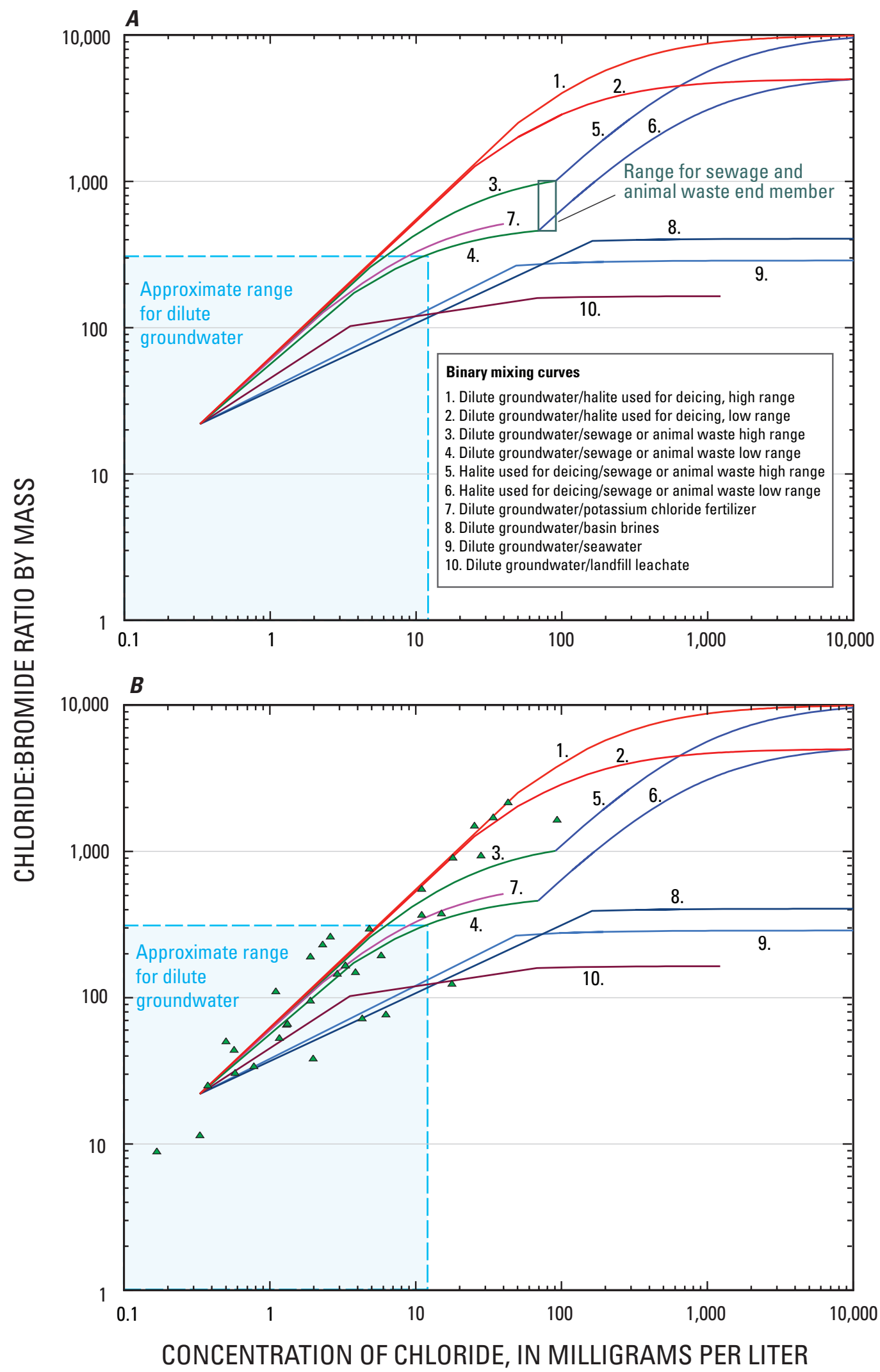

Figure 9. (A) Binary mixing curves representing sources of chloride. The relation of chloride concentration to chloride:bromide ratios (by mass) for samples from shallow monitoring wells in $(B)$ forested areas, $(C)$ agricultural areas, and $(D)$ urban areas. 


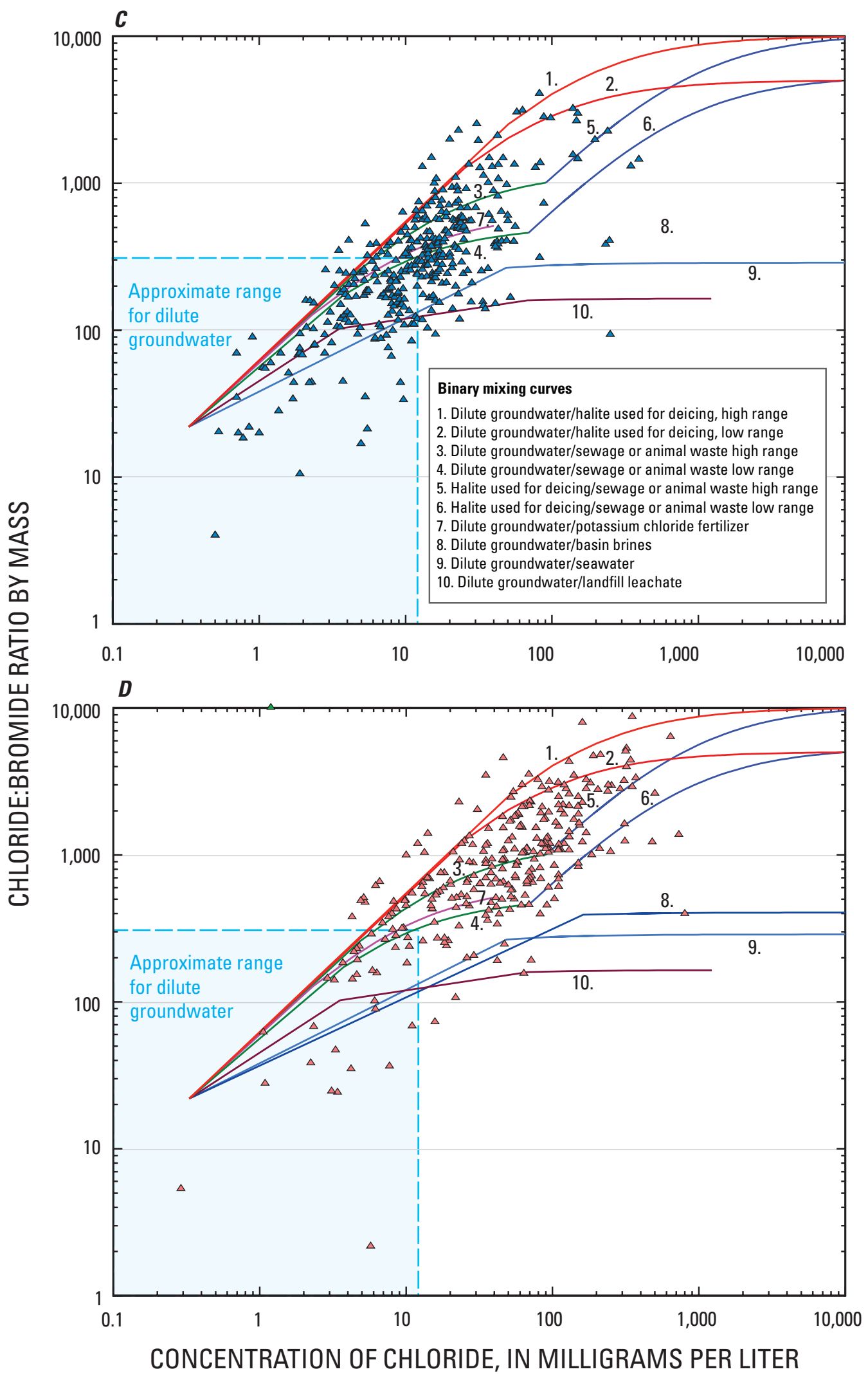

Figure 9. (A) Binary mixing curves representing sources of chloride. The relation of chloride concentration to chloride:bromide ratios (by mass) for samples from shallow monitoring wells in $(B)$ forested areas, $(C)$ agricultural areas, and $(D)$ urban areas.-Continued 
Table 4. Chloride:bromide ratios for sources of chloride to water resources.

[mg/L, milligrams per liter; $\mathrm{Cl}: \mathrm{Br}$, chloride to bromide ratio by mass; shaded areas represent end members used to draw binary mixing curves]

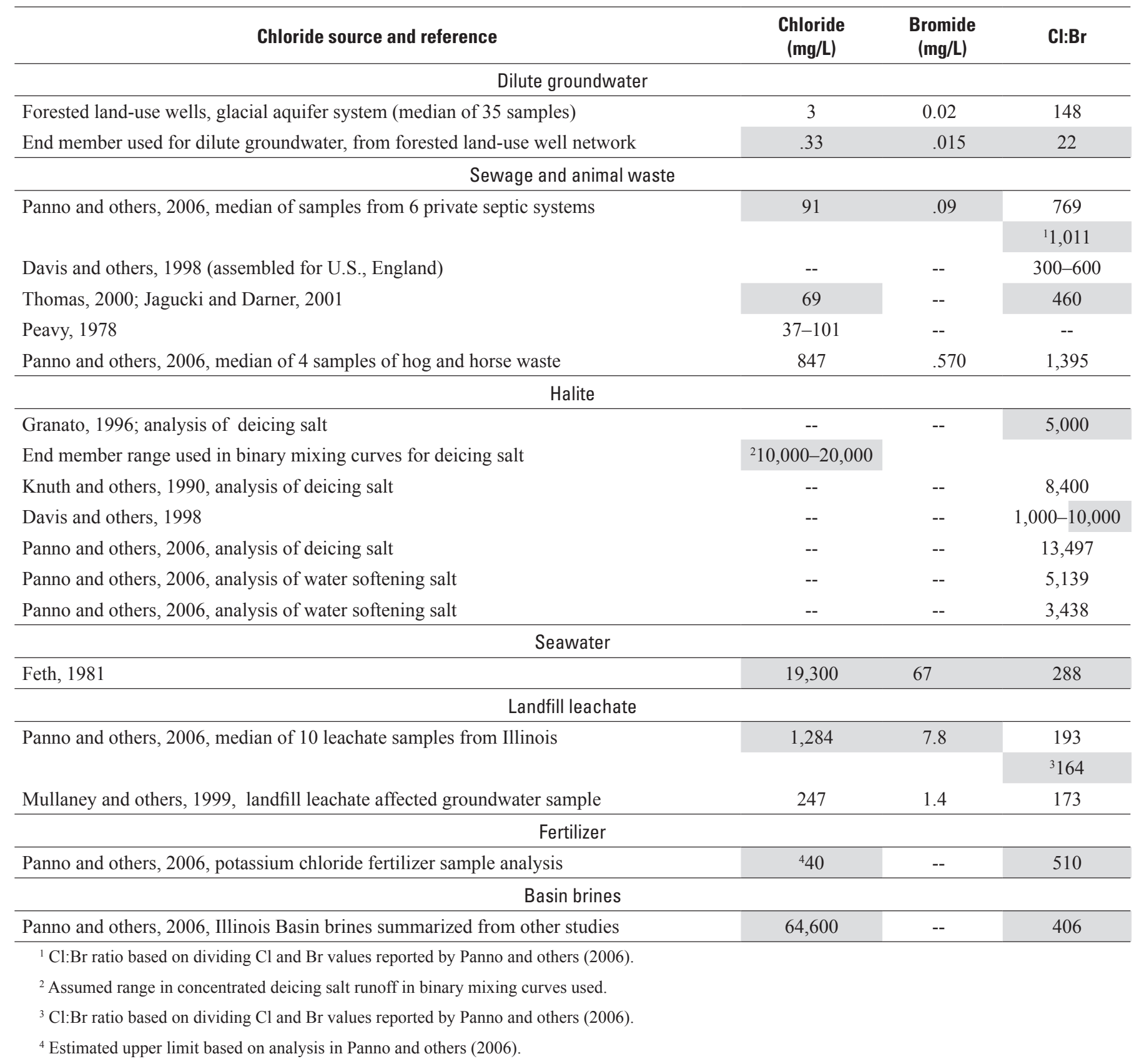




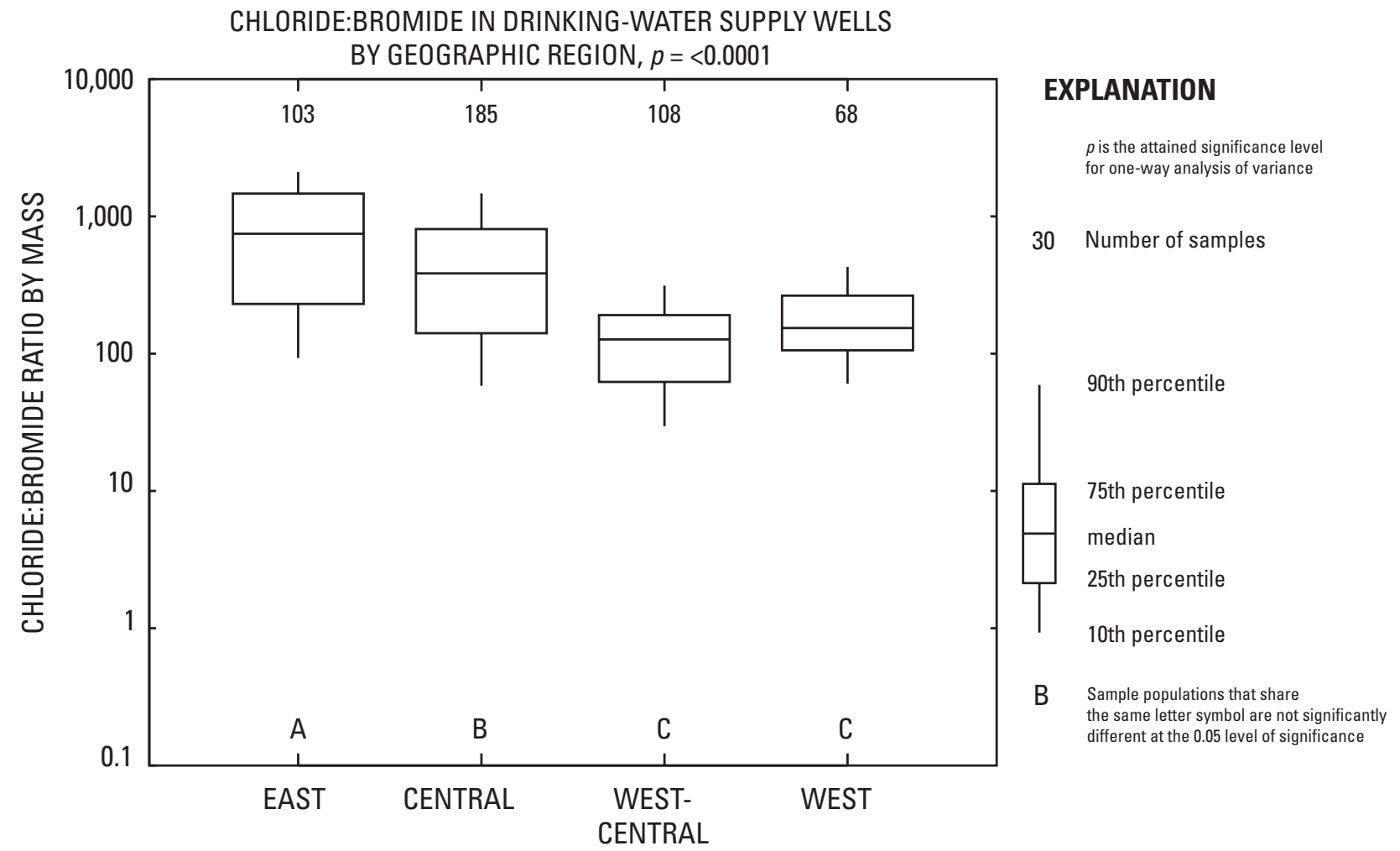

Figure 10. Distribution of chloride:bromide ratios (by mass) in samples from drinking-water supply wells in geographic regions of the glacial aquifer system, northern United States, 1991-2003.

\section{Relation of Chloride Yield to Explanatory Variables}

A multiple linear regression model was developed to describe the natural log of chloride yield. The data set included 15 forested basins, 41 agricultural basins, and 27 urban basins. Four variables (table 7) explained 69 percent of the variability in the natural log of chloride yield. Significant variables selected or modified from table 3 and shown in table 7 were Highway density and the Number of major discharges upstream of monitoring site in USEPA PCS database + (plus) 1 , potential evapotranspiration, and the difference between the percent of urban and agricultural land. Model residuals were approximately normally distributed, with a constant variance (fig. 16).

Major dischargers include municipal wastewater-treatment facilities with discharges greater than 1 million gallons per day (Mgal/d) and other facilities with discharges that have been rated by USEPA as major, based on volume and type of pollutants and type of receiving waters (Steven Winnett, U.S. Environmental Protection Agency, written commun., 2007). The variable "number of major discharges upstream of the monitoring site in the USEPA Permit Compliance System (PCS) database," if used alone in a simple linear regression model, explains about 17 percent of the variability in the chloride yield, indicating that wastewater discharges are a likely component of chloride loads in some streams sampled.

The significance of the variable Highway density (table 3 ) is probably related to areas that receive deicing salts in winter. The density of different road categories is generally correlated with urban land use and population density, and therefore other sources of chloride from urban settings cannot be excluded from this analysis. The difference between percent urban and percent agricultural land was only weakly correlated (correlation coefficient 0.44 ) with highway density, and explained an additional 14 percent of the variability in chloride yield.

\section{Trends in Loads at Selected Sites and Evaluation of Sources of Chloride}

Long-term data were available for 19 of the monitoring sites for which loads were estimated. Load estimates for three selected urban basins with long-term data were plotted to demonstrate visible trends with time by using a LOWESS smooth (Helsel and Hirsch, 2002) (figs. 17A-C). The apparent trends are similar to those reported by Kaushal and others (2005). Increases in chloride load over time generally can be 


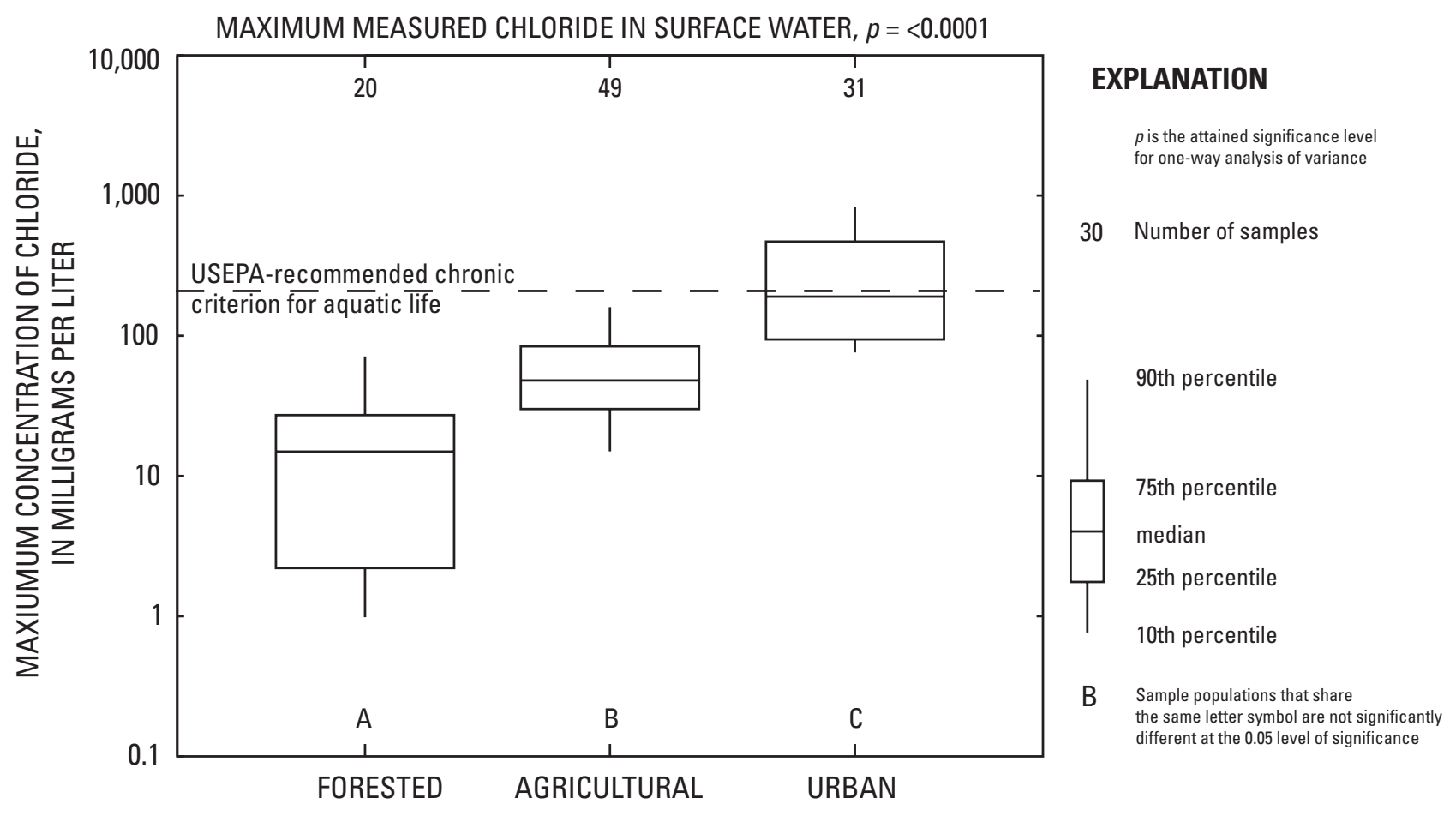

Figure 11. Distribution of maximum chloride concentrations measured at selected surface-water-quality monitoring stations in the glacial aquifer system, northern United States, 1991-2004.

attributed to changes in the application of deicing salt, the expansion of road networks and impervious areas that require deicing, increases in the number of septic systems, increases in the volume of wastewater discharge, and the arrival of saline groundwater plumes from landfills and salt-storage areas over time. These trends suggest that chloride concentrations in some urban basins may be greater than USEPA-recommended criteria in the coming years and decades.

Of the examples shown in figure 17, only Poplar Creek at Elgin, Illinois, receives no major wastewater discharges (Sullivan, 2000). The Rahway River near Springfield, New Jersey, may have some combined sewer overflows (J.G. Kennen, U.S. Geological Survey, written commun., 2006) and has 29 minor discharges listed in the PCS database.

The Quinnipiac River Basin in Connecticut was studied in greater detail to evaluate changes that have taken place during the period of record to determine potential causes for the increase in chloride load and the relative input from different sources. The chloride load at this station increased from less than 6,000 tons in water year 1982 to more than 9,000 tons in water year 2003 (fig. 17B). The average estimated chloride load from atmospheric deposition was 66 tons based on information used to create figure 3. The Quinnipiac River at Wallingford, Connecticut, had about $17 \mathrm{Mgal} / \mathrm{d}$ of wastewater discharge from three municipal wastewater-treatment facilities in 1998 (Mullaney and others, 2002); this represents about 12 percent of the average discharge for water years 1992 to 2003. In addition, the PCS database lists eight other major wastewater discharges, and four minor discharges.

The wastewater discharge is likely responsible for some of the chloride load. At a typical concentration of $91 \mathrm{mg} / \mathrm{L}$ for chloride in wastewater from sewage and animal waste (table 4), the load of chloride would be equivalent to about 2,360 tons per year, representing at least 20 percent of the load in 1998. An increase in wastewater discharge of $2.5 \mathrm{Mgal} / \mathrm{d}$ to the Quinnipiac River Basin from 1985 to 2001 was reported by Ahearn (2002). This may explain some of the increase (approximately 346 tons) in load that is apparent in figure 17B. Some of the chloride load in wastewater discharge is derived from the chloride initially in the drinkingwater supply. For instance, one upstream utility in Meriden, Connecticut, reported concentrations of chloride in drinking water as large as $250 \mathrm{mg} / \mathrm{L}$ (City of Meriden, Connecticut, 2005); therefore, some chloride that initially may be derived from anthropogenic sources may be recycled.

The load of chloride from residential septic systems in the Quinnipiac River Basin (not considering systems with water softeners) was estimated by determining the number of septic systems in the basin in 1990 and then applying block-group data from the 1990 Census on the method of 
Table 5. Monitoring stations where surface waters had chloride concentrations greater than 230 milligrams per liter in the glacial aquifer system, northern United States, 1991-2004.

[mg, milligram; L, liter; U, urban land use; A, agricultural land use]

\begin{tabular}{|c|c|c|c|c|c|c|c|c|c|c|c|c|c|c|c|c|c|c|}
\hline \multirow{2}{*}{$\begin{array}{l}\text { Station } \\
\text { identifier }\end{array}$} & \multirow{2}{*}{ Station name } & \multirow{2}{*}{$\begin{array}{l}\text { Dominant } \\
\text { land } \\
\text { use }\end{array}$} & \multirow{2}{*}{$\begin{array}{l}\text { Number } \\
\text { of } \\
\text { chloride } \\
\text { samples }\end{array}$} & \multirow{2}{*}{$\begin{array}{l}\text { Number of } \\
\text { samples } \\
\text { greater } \\
\text { than } 230 \\
\mathrm{mg} / \mathrm{L}\end{array}$} & \multirow{2}{*}{$\begin{array}{l}\text { Per- } \\
\text { cent }\end{array}$} & \multirow{2}{*}{$\begin{array}{l}\text { Maxi- } \\
\text { mum } \\
\text { chloride } \\
\text { concen- } \\
\text { tration } \\
\text { (mg/L) }\end{array}$} & \multicolumn{12}{|c|}{ Months with concentration greater than $230 \mathrm{mg} / \mathrm{L}$} \\
\hline & & & & & & & $\mathbf{J}$ & $\mathbf{F}$ & M & A & $\mathbf{M}$ & $\mathbf{J}$ & $\mathbf{J}$ & A & S & 0 & $\mathbf{N}$ & D \\
\hline 01102500 & $\begin{array}{l}\text { Aberjona River } \\
\text { at Winchester, } \\
\text { Massachusetts }\end{array}$ & $\mathrm{U}$ & 127 & 12 & 9.4 & 673 & $\mathrm{X}$ & $\mathrm{X}$ & $\mathrm{X}$ & $\mathrm{X}$ & & & & & & & & $\mathrm{X}$ \\
\hline 01356190 & $\begin{array}{l}\text { Lisha Kill north- } \\
\text { west of } \\
\text { Niskayuna, } \\
\text { New York }\end{array}$ & $\mathrm{U}$ & 90 & 7 & 7.8 & 353 & $\mathrm{X}$ & $\mathrm{X}$ & $\mathrm{X}$ & & & & & & & & & \\
\hline 01391500 & $\begin{array}{l}\text { Saddle River at } \\
\text { Lodi, New } \\
\text { Jersey }\end{array}$ & $\mathrm{U}$ & 59 & 1 & 1.7 & 408 & & & & & & & & & & & & $\mathrm{X}$ \\
\hline 03353637 & $\begin{array}{l}\text { Little Buck } \\
\text { Creek near } \\
\text { Indianapolis, } \\
\text { Indiana }\end{array}$ & $\mathrm{U}$ & 205 & 4 & 2.0 & 470 & $\mathrm{X}$ & X & $X$ & & & & & & & & & \\
\hline 04072050 & $\begin{array}{l}\text { Duck Creek at } \\
\text { Seminary } \\
\text { Road near } \\
\text { Oneida, } \\
\text { Wisconsin }\end{array}$ & A & 93 & 2 & 2.2 & 425 & $\mathrm{X}$ & & $X$ & & & & & & & & & \\
\hline 04186500 & $\begin{array}{l}\text { Auglaize River } \\
\text { near Fort } \\
\text { Jennings, Ohio }\end{array}$ & A & 80 & 1 & 1.3 & 251 & & & & & & & & & & X & & \\
\hline 05288705 & $\begin{array}{c}\text { Shingle Creek at } \\
\text { Queen Avenue } \\
\text { in Minneapo- } \\
\text { lis, Minnesota }\end{array}$ & $\mathrm{U}$ & 115 & 25 & 21.7 & 2,020 & $\mathrm{X}$ & $X$ & $X$ & & & & & & & & $X$ & $\mathrm{X}$ \\
\hline 05330902 & $\begin{array}{l}\text { Nine Mile Creek } \\
\text { near James } \\
\text { Circle at } \\
\text { Bloomington, } \\
\text { Minnesota }\end{array}$ & $\mathrm{U}$ & 56 & 7 & 12.5 & 522 & $\mathrm{X}$ & $X$ & $X$ & & & & & & & & & \\
\hline
\end{tabular}


Table 5. Monitoring stations where surface waters had chloride concentrations greater than 230 milligrams per liter in the glacial aquifer system, northern United States, 1991-2004.-Continued

[mg, milligram; L, liter; U, urban land use; A, agricultural land use]

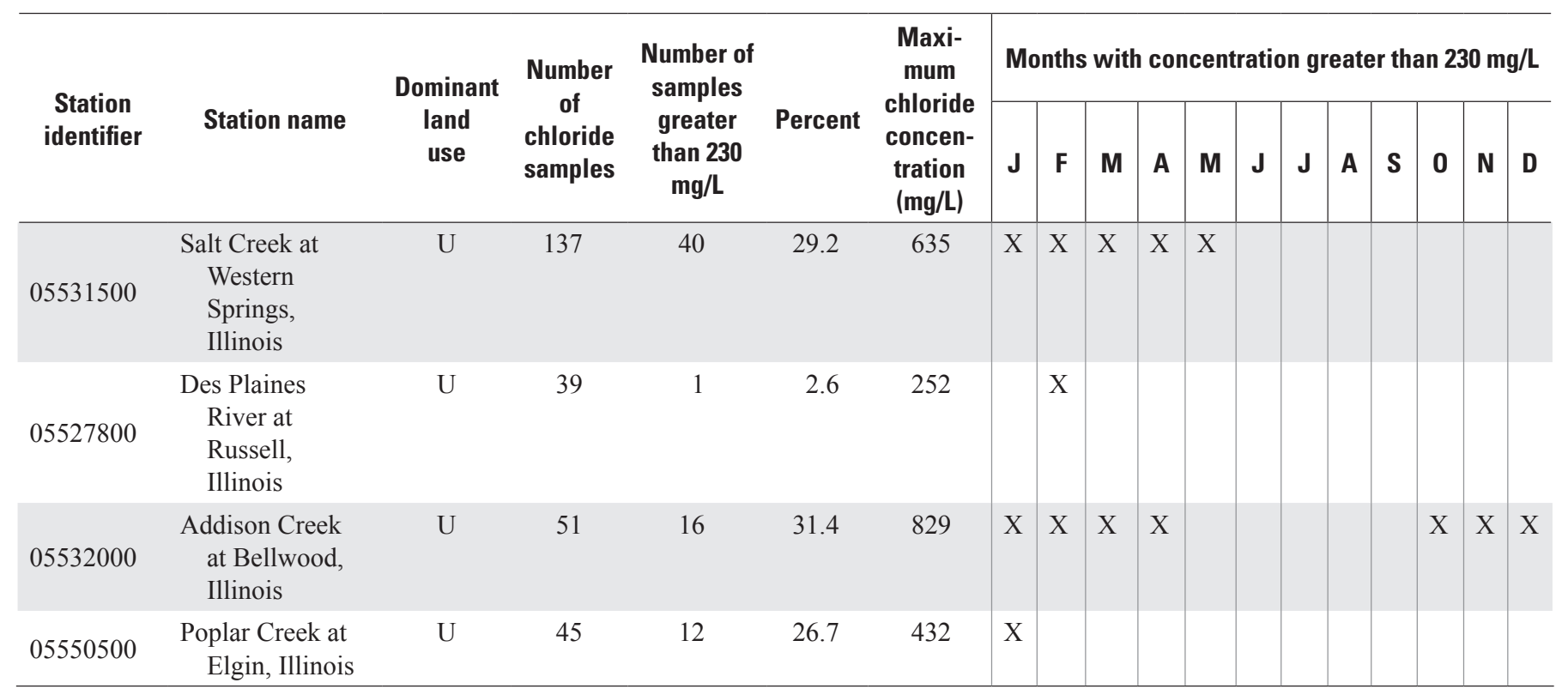

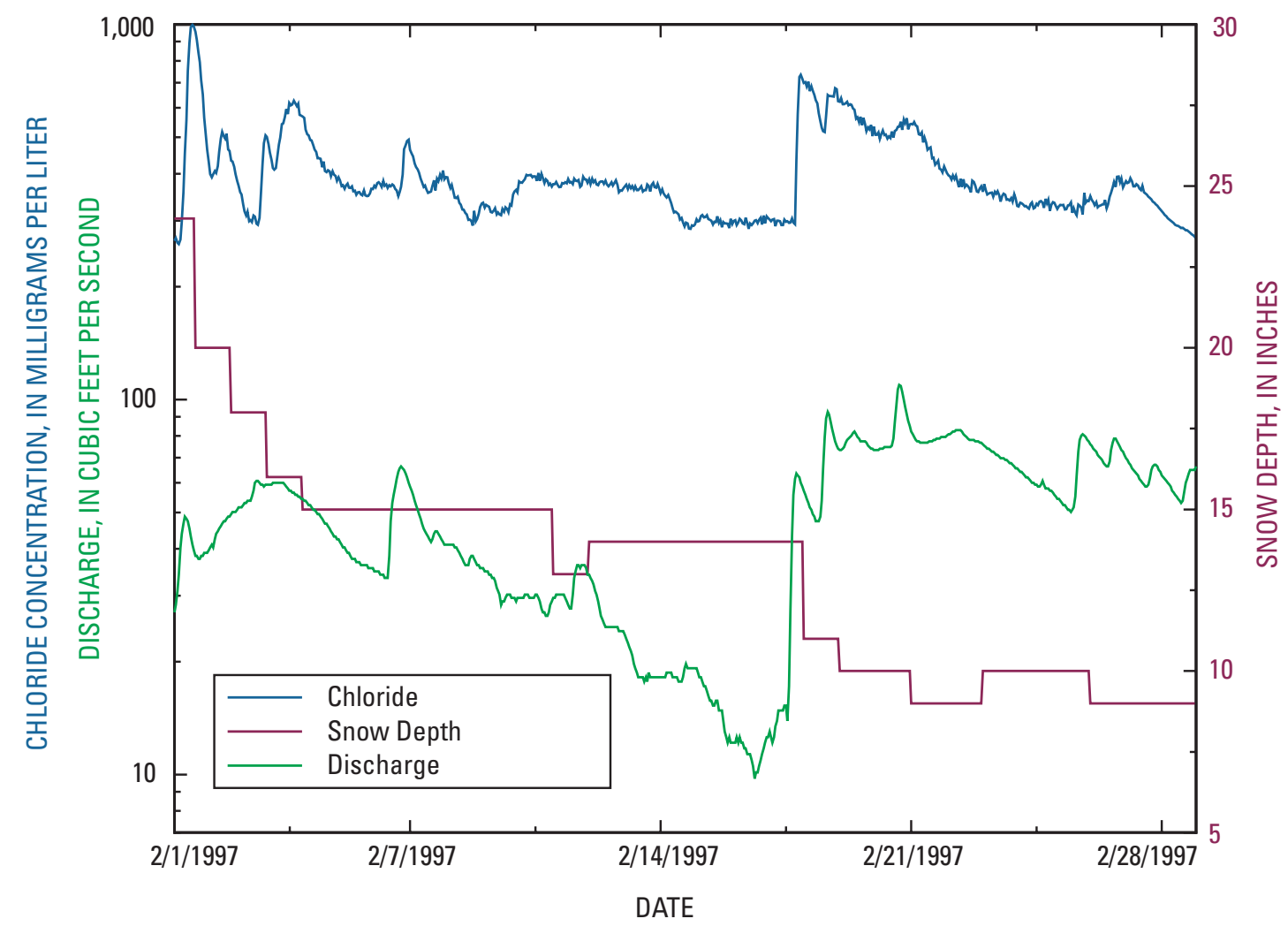

Figure 12. Chloride concentrations, snow depth, and discharge at station 05288705, Shingle Creek at Queen Avenue in Minneapolis, Minnesota, February 1997. (Data from James Fallon, U.S. Geological Survey, written commun., 2006.) 


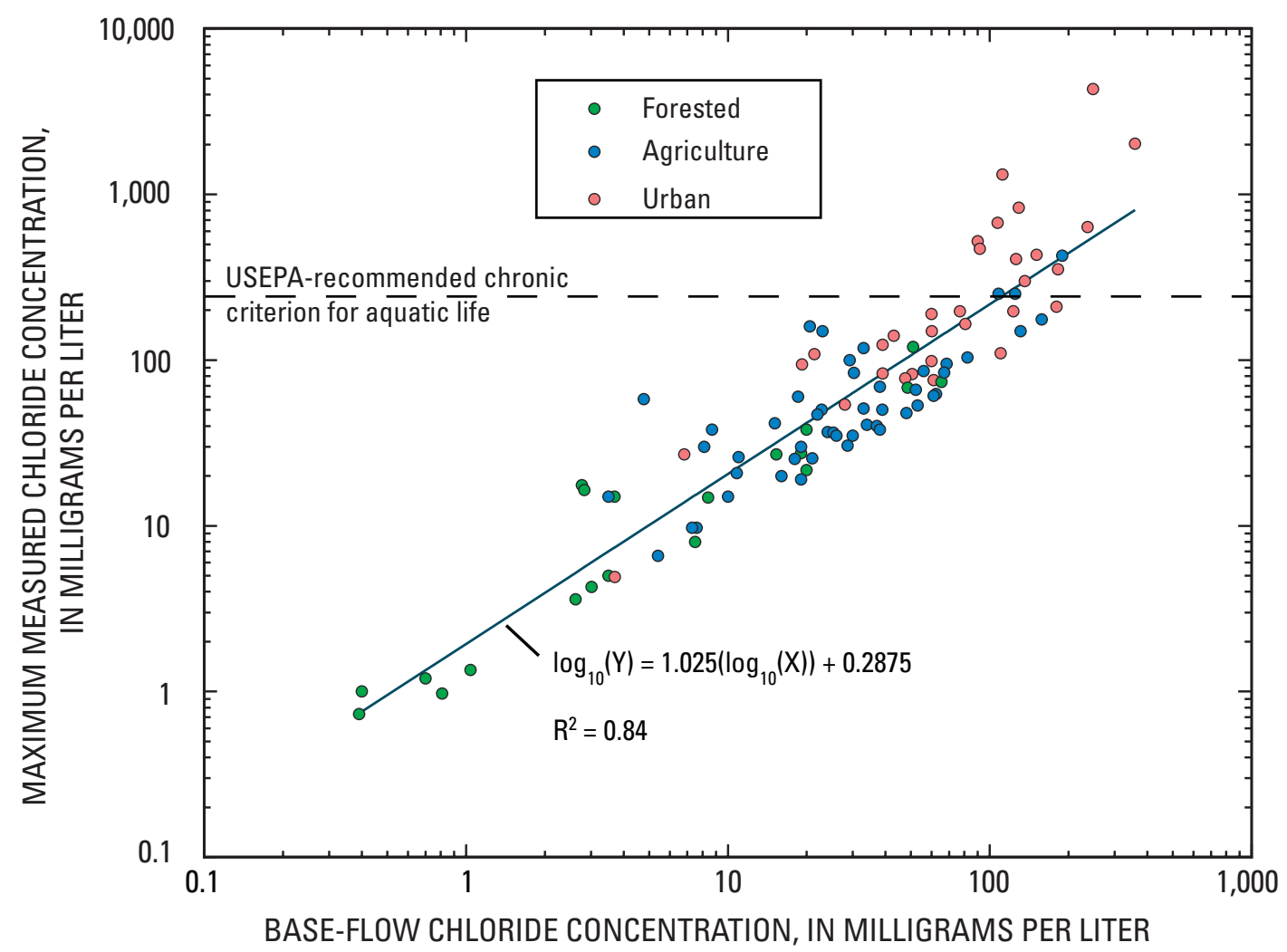

Figure 13. Chloride concentrations in base flow, plotted against maximum measured chloride concentrations at selected forested, agricultural, and urban basins in the glacial aquifer system, northern United States, 1991-2004.

Table 6. Multiple linear-regression estimates of model coefficients, standard errors, $t$-statistic and $p$-values for the dependent variable natural log of maximum measured chloride concentration in surface water for selected urban, agricultural, and forested basins, in the glacial aquifer system, northern United States, 1991-2004.

[mi, mile; $\mathrm{mi}^{2}$, square mile; mm, millimeter; yr, year; <, less than; -, minus]

\begin{tabular}{|c|c|c|c|c|c|}
\hline Variable & Units & Parameter estimate & Standard error & $t$-statistic & $p$-value \\
\hline Intercept & Dimensionless & -8.3728 & 1.6394 & -5.1071 & $<0.0001$ \\
\hline Major road density & $\mathrm{mi} / \mathrm{mi}^{2}$ & 1.1229 & .1498 & 7.4941 & $<.0001$ \\
\hline $\begin{array}{l}\text { Percent Dunne overland flow } \\
\text { (saturated overland flow) }\end{array}$ & $\begin{array}{l}\text { Percent of annual stream- } \\
\text { flow }\end{array}$ & -.4547 & .1061 & -4.2838 & .0001 \\
\hline
\end{tabular}




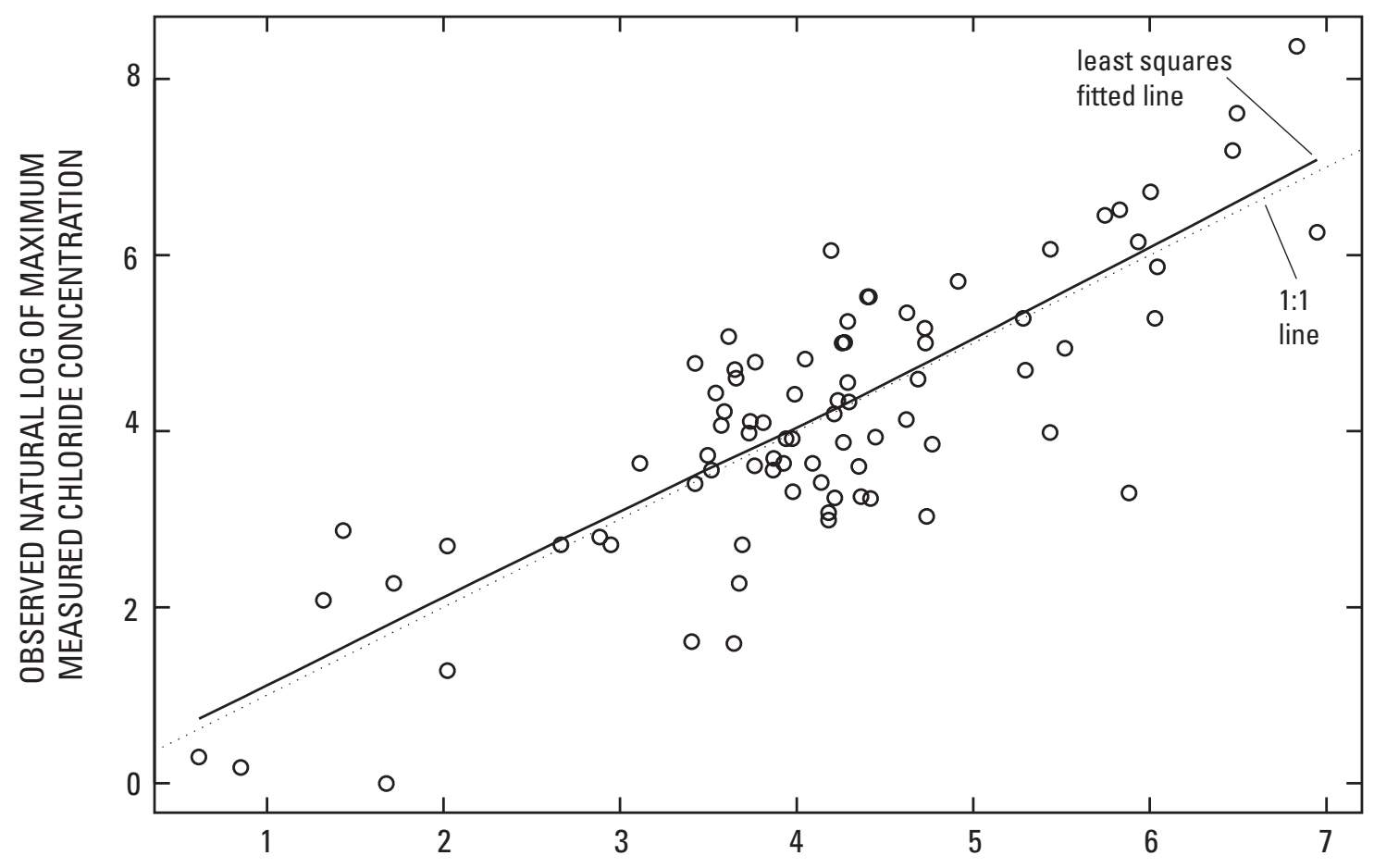

PREDICTED NATURAL LOG OF MAXIMUM MEASURED CHLORIDE CONCENTRATION

Figure 14. Predicted natural log of maximum measured chloride concentrations from multiple linear regression modeling, and observed natural log of maximum measured chloride concentrations in selected forested, agricultural, and urban basins in the glacial aquifer system, northern United States, 1991-2004.

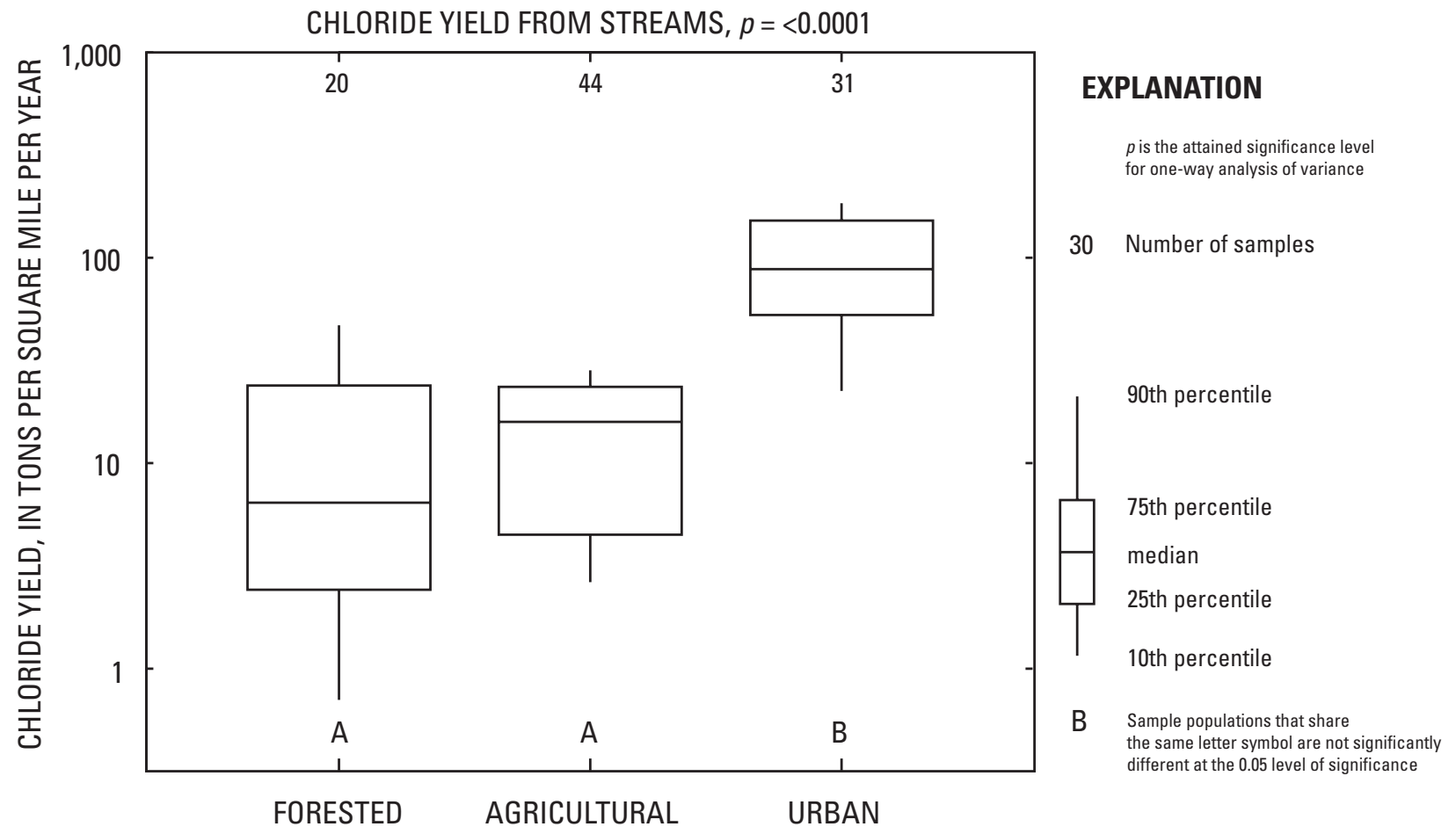

Figure 15. Distribution of annual mean chloride yields at selected surface-water-quality monitoring stations in the glacial aquifer system, northern United States, 1991-2003. 
Table 7. Multiple linear regression estimates of model coefficients and standard errors, $t$-statistics, and $p$-values for the dependent variable natural log of chloride yield in selected forested, agricultural and urban basins in the glacial aquifer system, northern United States, 1991-2003.

[mi, mile; mm, millimeter; yr, year; USEPA PCS, U.S. Environmental Protection Agency Permit Compliance System; NLCDe, National Landcover Dataset (Vogelmann and others (1998), enhanced by Nakagaki and Wolock (2005)); +, plus; -, minus; <, less than]

\begin{tabular}{|c|c|c|c|c|c|}
\hline Variable & Units & Parameter estimate & Standard error & $t$-statistic & $p$-value \\
\hline Intercept & Dimensionless & -5.0085 & 1.0433 & -4.8005 & $<0.0001$ \\
\hline $\begin{array}{l}\text { Highway density (U.S. numbered } \\
\text { routes; does not include limited } \\
\text { access highways) }\end{array}$ & $\mathrm{mi} / \mathrm{mi}^{2}$ & 2.3846 & .8936 & 2.6687 & .0093 \\
\hline $\begin{array}{l}\text { natural log of (number of major } \\
\text { discharges upstream of monitoring } \\
\text { site in USEPA PCS database+1) }\end{array}$ & Dimensionless & .4149 & .1809 & 2.2934 & .0245 \\
\hline $\begin{array}{l}\text { Potential evapotranspiration 1961-90 } \\
\text { (effect applied only up to } 700 \mathrm{~mm} / \\
\text { year) }\end{array}$ & $\mathrm{mm} / \mathrm{yr}$ & .0123 & .0017 & 7.2562 & $<.0001$ \\
\hline $\begin{array}{l}\text { Percent of urban-agricultural land } \\
\text { (NLCDe) }\end{array}$ & Percent of basin area & .0109 & .0018 & 5.9849 & $<.0001$ \\
\hline
\end{tabular}

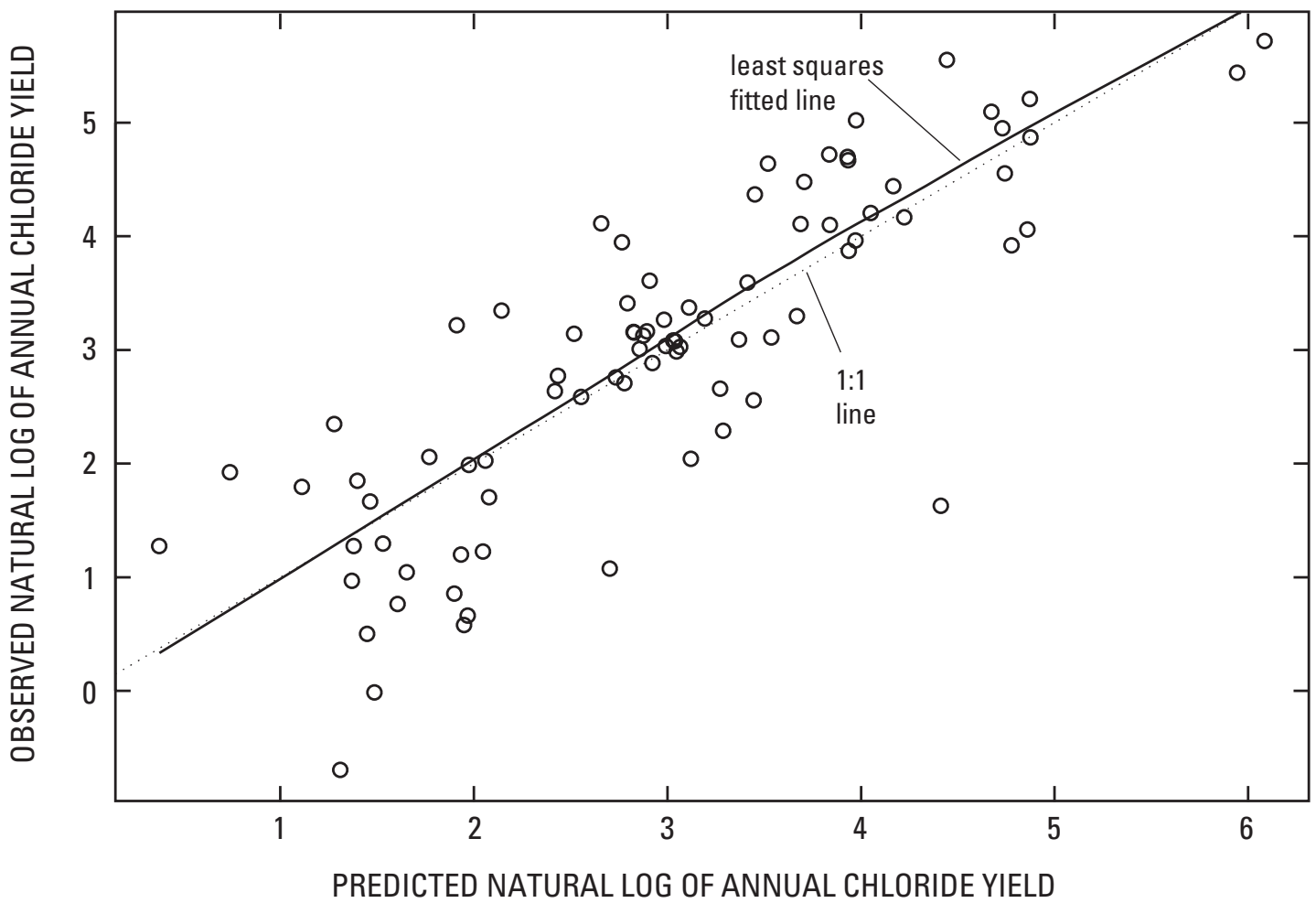

Figure 16. Predicted natural log of annual chloride yield from multiple linear regression modeling and observed natural log of chloride yield in selected forested, agricultural, and urban basins in the glacial aquifer system, northern United States, 1991-2003. 

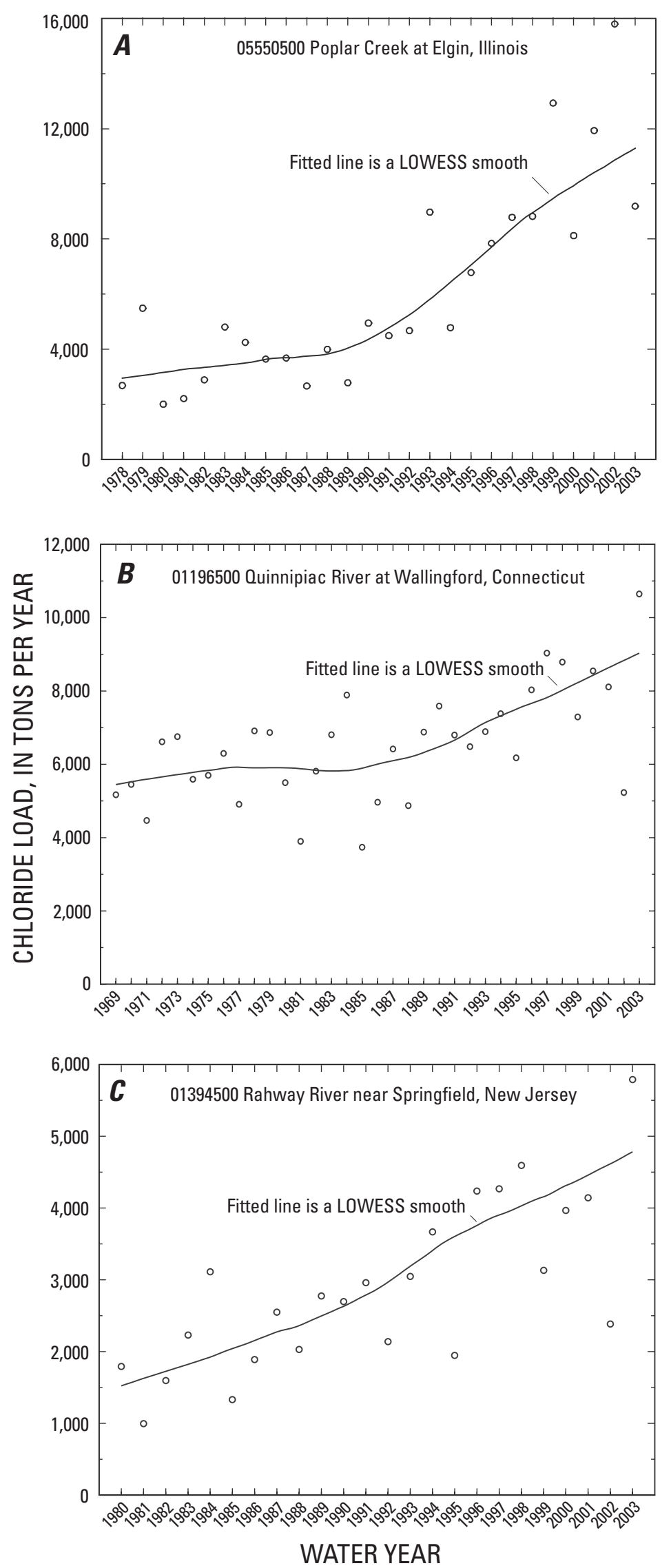

Figure 17. Chloride loads with time at selected waterquality monitoring stations in the glacial aquifer system, northern United States: (A) Poplar Creek at Elgin, Illinois, water years 1978-2003; (B) Quinnipiac River at Wallingford, Connecticut, water years 1969-2003; and (C) Rahway River near Springfield, New Jersey, water years 1980-2003. 
sewage disposal (U.S. Department of Commerce, 1991). The estimated number of septic systems in the basin upstream from the monitoring station was 10,400 . By using the estimated chloride concentration of $91 \mathrm{mg} / \mathrm{L}$ for wastewater (table 4) and assuming $300 \mathrm{gal} / \mathrm{d}$ of water use per household, the estimated load of chloride from septic systems was 430 tons in 1990. The number of septic systems likely has increased since 1990, and the presence of water softeners could increase this load substantially.

The other likely source of the increase in chloride load in this basin is the increase in the impervious area, including roads, during the period of record, and subsequent increases in deicing these areas. The impervious area of the basin above the Quinnipiac monitoring station was analyzed for 1985 and 2002 using the Impervious Surface Analysis Tool (ISAT) described by Chabaeva and others (2004). This method was used with impervious surface coefficients developed for Connecticut and population-density classes (Prisloe and others, 2003). The University of Connecticut has developed consistently interpreted satellite imagery for Connecticut land use and land cover for 1985, 1990, 1995, and 2002 (Civco and others, 1998). The ISAT method estimated that the impervious cover for the basin upstream from the monitoring station was 13.3 percent in 1985 , but increased to 14.7 percent in 2002 an increase of 1.4 percent, or about 890 acres. In addition to these increases, Interstate 691 was completed in 1988, adding about 5.5 miles of four-lane road, and an estimated 85 tons of deicing salt (or about 52 tons of chloride) (Patrick Rodgers, Connecticut Department of Transportation, oral commun., 2004). Additional potential sources of chloride include 9 salt-storage areas and 20 landfills (Connecticut Department of Environmental Protection, 1995). This analysis indicates that although deicing salts may be the dominant input of chloride in many of the urban basins studied, other sources should be considered in the establishment of Total Maximum Daily Loads (TMDLs).

\section{Summary and Conclusions}

The use of salt in the United States has increased since the 1950s. Salt use has increased from 42.9 million tons in 1975 to nearly 58.5 million tons in 2005 . However, the largest use of salt for many years has been the chloralkali industry. In 2005 the largest use was for deicing (39.5 percent), followed by use in the chloralkali industry (34.7 percent). The remaining uses total about 25 percent. The Northern States that compose the glacial aquifer system were the end destination for about 76 percent of the shipments of evaporated salt and rock salt.

Chloride concentrations were greater than the U.S. Environmental Protection Agency secondary maximum contaminant level (SMCL) of 250 milligrams per liter in 2.5 percent of samples from 797 shallow monitoring wells sampled (land-use wells), and in 1.7 percent of 532 drinking-water supply wells sampled from 1991 to 2003. Chloride concentrations were largest in samples from shallow monitoring wells in urban areas (median concentration of 46 milligrams per liter), followed by the concentrations in samples from agricultural areas (median, 12 milligrams per liter), and forested areas (median, 2.9 milligrams per liter).

Chloride:bromide ratios, by mass, in groundwater samples were plotted against chloride concentrations along with binary mixing curves for different sources of chloride. Samples from shallow monitoring wells in the urban areas had the largest ratios of chloride to bromide, and generally plotted on or between binary mixing curves for dilute groundwater, and (1) halite, (2) sewage and animal waste, and (3) potassium chloride fertilizer; these results indicate mixed sources of chloride. Samples that had a chloride:bromide ratio greater than 460 are dominated by anthropogenic sources of chloride. Samples that had a chloride:bromide ratio greater than 1,000 and chloride concentrations greater than 100 milligrams per liter are likely dominated by halite by mass, but may contain lesser proportions of other sources.

Samples from shallow monitoring wells in agricultural areas were not dominated by any one source of chloride, but there was a cluster of points representing samples that plotted on or near the binary mixing lines for dilute groundwater and potassium chloride or dilute groundwater and sewage and animal waste. Sources of chloride in agricultural areas include deicing salt, salt used in animal feeds, water-softening salts, salts in animal waste and fertilizer, and the use of irrigation water containing brines.

Ratios for samples from drinking-water wells indicated mixed sources of chloride, but two general patterns emerged when chloride:bromide ratios were compared by well type (private domestic drinking-water wells, and public drinkingwater wells) and by region in the glacial aquifer system. The chloride:bromide ratios of the samples from the public drinking-water wells were significantly larger than for the private domestic wells, indicating anthropogenic sources of chloride. This may be a result of the integration of water of different depths and ages into public drinking-water wells due to pumping. Drinking-water-well samples from the east region of the glacial aquifer system had the highest chloride:bromide ratios followed by the central region. Samples from the west-central and west areas had low chloride:bromide ratios, indicating less human influence on water quality.

Data collected from 1991 to 2004 from 100 surface-water monitoring sites in the glacial aquifer system draining land dominated by forested land cover or urban, and agricultural land use were analyzed to compare chloride concentrations to USEPA-recommended chronic aquatic criteria, to relate maximum measured chloride concentrations to ancillary factors, and to compute annual loads so that chloride yields could be compared. Fifteen (12 urban, 3 agricultural) of the 100 sites had samples with concentrations greater than the USEPA-recommended aquatic criteria concentration for chloride of 230 milligrams per liter. Six of the 15 sites had 10 percent or more of their values greater than 230 milligrams 
per liter, indicating frequent occurrence of high concentrations. Concentrations of chloride greater than 230 milligrams per liter occurred most frequently during the months from November to April, indicating a likely relation with winter deicing activities.

Sites with maximum concentrations of chloride greater than 230 milligrams per liter had base-flow concentrations of chloride greater than 75 to 90 milligrams per liter. This result indicates that basins with high chloride concentrations in groundwater or wastewater discharge were more likely to exceed the recommended chronic criteria.

A multiple linear regression model was used to describe the natural $\log$ of the maximum measured chloride at 84 surface-water-monitoring stations that had ancillary data. Significant variables were the density of major roads (roads in the U.S. highway system), potential annual evapotranspiration, and the percentage of the annual streamflow derived from saturated overland flow (runoff).

The load of chloride was determined for each of 95 surface-water monitoring stations for the years with data collected from 1991 to 2003. The loads were normalized by drainage area to calculate yields of chloride. The median chloride yield was 88 tons per square mile from the basins dominated by urban land use, 15.4 tons per square mile from agricultural basins, and 6.4 tons per square mile from forested basins. The significant variables to describe chloride yields were highway density, number of major wastewater discharges, potential evapotranspiration, and percentage of urban minus agricultural land in each watershed.

Long-term historical data and the literature on this subject suggest that chloride concentrations in streams are currently increasing in urbanized and urbanizing areas, potentially exceeding recommended criteria for aquatic life now or in the coming decades. Increases in chloride load over time generally can be attributed to changes in the application of deicing salt, the expansion of road networks and impervious areas that require deicing, increases in the number of septic systems, increases in the volume of wastewater discharge, and the arrival of saline groundwater plumes from landfills and saltstorage areas over time.

Data from the Quinnipiac River in Connecticut were analyzed to explore the role of different sources of chloride in the overall chloride load. The analysis indicated that in basins with a high volume of wastewater discharge and a moderate to high density of septic systems, at least 31 percent of the chloride load can be derived from these sources. The wet deposition of chloride from precipitation represents less than one percent of the chloride load. The source of the chloride in wastewater and septic-system leachate can include chloride recycled from anthropogenic sources in the public and private water supplies; landfills and storage sites for deicing chemicals represent additional anthropogenic sources. A large part of the remaining load can be attributed to the use of deicing salt on impervious areas.

\section{References Cited}

Ahearn, E.A., 2002, Streamflow in the Quinnipiac River

Basin, Connecticut-Statistics and trends, 1931-2000: U.S. Geological Survey Water-Resources Investigations Report 02-4217, $42 \mathrm{p}$.

Aultman-Hall, L., Mahoney, J., and Zinke, S., 2006, Improving winter highway maintenance - Case studies for Connecticut's consideration: Connecticut Academy of Science and Engineering, Hartford, Connecticut, 44 p.

Briggs, J.C., and Ficke, J.F., 1977, Quality of rivers of the United States, 1975 Water Year-Based on the National Stream Quality Accounting Network (NASQAN): U.S. Geological Survey Open-File Report 78-200, 436 p.

Bubeck, R.C., Diment, W.H., Deck, B.L., Baldwin, A.L., and Lipton, S.D., 1971, Runoff of deicing salt-Effect on Irondequoit Bay, Rochester, New York: Science, v. 172, p. 1128-1132.

CH2M HILL Inc., 2003, Total maximum daily loads for Salt Creek Illinois, Draft Report: Herndon, Virginia, [variously paginated].

Chabaeva, A.A., Civco, D.L., and Prisloe, S., 2004, Development of a population and land use based regression model to calculate the amount of imperviousness, in Proceedings of the annual ASPRS convention, Denver, Colorado, 2004, 9 p., accessed on September 10, 2009 at http://nemo.uconn.edu/tools/impervious_surfaces/pdfs/ Chabaeva_etal_2004.pdf.

Church, P.E., Armstrong, D.S., Granato, G.E., Stone, V.J., Smith, K.P., Provencher, P.L., 1996, Effectiveness of highway-drainage systems in preventing contamination of ground water by road salt, Route 25 , southeastern Massachusetts; description of study area, data collection programs, and methodology: U.S. Geological Survey Open File Report 96-317, 72 p.

City of Elgin, Illinois, Snow and Ice Control, Web page accessed in 2005 at $h t t p: / / w w w . c i t y o f e l g i n . o r g / i n d e x$. asp? $N I D=180$.

City of Gurnee, Illinois, Street Division, Web page accessed on March 30, 2009 at http://www.gurnee.il.us/public_works/ about.html\#streetdivision.

City of Meriden, Connecticut, 2005, 2005 annual water qual-

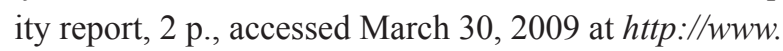
cityofmeriden.org/forms/customer-files/208-2006MeridenQualityReportBrochureFinal2.pdf. 
Civco, D.L., Arnold, C.L., Hurd, J.D., 1998, Land use and land cover mapping for the Connecticut and New York portions of the Long Island Sound Watershed: Office of Long Island Sound Programs, Connecticut Department of Environmental Protection, Research Project CWF 330-R Technical Completion Report [unpaginated].

Colombo, M.J., and Trench, E.C.T., 2002, Trends in surfacewater quality in Connecticut: U.S. Geological Survey Water-Resources Investigations Report 02-4012, 39 p.

Connecticut Department of Environmental Protection, 1995, Leachate and wastewater discharge inventory: Connecticut Department of Environmental Protection, Environmental and Geographic Information Center, Hartford, Connecticut, Digital Shapefile, 1:50,000, accessed on September 10, 2009 at http://www.ct.gov/dep/cwp/view. asp? $A=2698 \& Q=322898$.

Daly, C., Neilson, R.P., and Phillips, D.L., 1994, A statisticaltopographic model for mapping climatological precipitation over mountainous terrain: Journal of Applied Meteorology, v. 33 , p. $140-158$.

Davis, S.N., Whittemore, D.O., Fabryka-Martin, J., 1998, Uses of chloride/bromide ratios in studies of potable water: Ground Water, v. 36, no. 2, p 338-350.

Dunne, T., Black, R.D., 1970, Partial area contributions to storm runoff in a small New England watershed: Water Resources Research, v. 6, no. 5, p. 1296-1311.

ESRI, Inc., 2006, Tele Atlas North America, ESRI data and maps - Streetmap, Redlands California, geospatial data set.

Feth, J.H., 1965, Preliminary map of the conterminous United States showing depth to and quality of shallowest ground water containing more than 1,000 parts per million dissolved solids: U.S. Geological Survey Hydrologic Atlas 199, 2 sheets.

Feth, J.H., 1981, Chloride in natural continental water-A review: U.S. Geological Survey Water Supply Paper 2176, $30 \mathrm{p}$.

Fong, A.L., 2000, Water-quality assessment of part of the Upper Mississippi River Basin, Minnesota and WisconsinGround-water quality in three different land-use areas, 1996-98: U.S. Geological Survey Water-Resources Investigations Report 00-4131, 37 p.

Fuss \& O’Neill, Inc., 1997, North End Disposal Area, quarterly operations and water quality monitoring report, Waterbury, Connecticut, August 1997.

Gilliom, R.J., Alley, W.M., and Gurtz, M.E., 1995, Design of the National Water-Quality Assessment ProgramOccurrence and distribution of water-quality conditions: U.S. Geological Survey Circular 1112, 33 p.
Grady, S.J., and Mullaney, J.R., 1998, Natural and human factors affecting shallow water quality in surficial aquifers in the Connecticut, Housatonic, and Thames River Basins: U.S. Geological Survey Water-Resources Investigations Report 98-4042, 81 p.

Granato, G.E., Church, P.E., Stone, V.J., 1995, Mobilization of major and trace constituents of highway runoff in groundwater potentially caused by deicing-chemical migration: Washington D.C., Transportation Research Record 1483, Transportation Research Board, National Research Council, p. 92-104.

Granato, G.E., 1996, Deicing chemicals as a source of constituents in highway runoff: Washington D.C., Transportation Research Record 1533, Transportation Research Board, National Research Council, p. 50-58.

Hay, L.E., and Campbell, J.P., 1990, Water-quality trends in New Jersey streams: U.S. Geological Survey WaterResources Investigations Report 90-4046, 297 p.

Heisig, P.M., 2000, Effects of residential and agricultural land use on the chemical quality of baseflow of small streams in the Croton watershed, southeastern New York: U.S. Geological Survey Water-Resources Investigations Report, 99-4173, 15 p.

Helsel, D.R., and Hirsch, R.M., 2002, Statistical methods in water resources: Techniques of Water-Resources Investigations, book 4, chap. A3, 510 .

Hintz, G., Kettlewell, A., Shambarger, E., Sweeney, T., 2001, Milwaukee's snow and ice control service, in La Follette Policy Report: Madison, Wisconsin, Robert M. La Follete School of Public Affairs, v. 12, no. 1, p. 16-20, accessed on March 30, 2009 at http://www.lafollette.wisc.edu/publications/policyreports/policyReport12_1.pdf.

Huling, E.E., and Hollocher, T.C., 1972, Groundwater contamination by road salt-Steady-state concentrations in east-central Massachusetts: Science, v. 176, p. 288-290.

Indiana Department of Transportation, 2004, Making our highways safer, accessed at www.ai.org/indot/files/Safety.pdf.

Insightful Corporation, 2005, S-Plus 7-Statistical application software: accessed December 15, 2006, at http://www. insightful.com/products/splus/default.asp.

Jagucki, M.L., Darner, R.A., 2001, Ground-water quality in Geauga County, Ohio-Review of previous studies, status in 1999, and comparison of 1986 and 1999 data: U.S. Geological Survey Water-Resources Investigations Report 01-4160, 61 p.

Jones, A.L., and Sroka, B.N., 1997, Effects of highway deicing chemicals on shallow unconsolidated aquifers in Ohio, interim report, 1988-93: U.S. Geological Survey WaterResources Investigations Report 97-4027, 139 p. 
Kaushal, S.J., Groffman, P.M., Likens, G.E., Belt, K.T., Stack, W.P., Kelly, V.R., Band, L.E., and Fisher, D.T., 2005, Increased salinization of fresh water in the northeastern United States: Proceedings of the National Academy of Sciences, v. 102, no. 38, p. 13,517-13,520.

Knuth, M., Jackson, J.L., and Whittemore, D.O., 1990, An integrated approach to identifying the salinity source contaminating a ground-water supply: Ground Water, v. 28, no. 2, p. 207-214.

Kostick, D.S., 1993, The material flow of salt: Bureau of Mines, Information Circular 9343, 32 p.

Kostick, D.S. , Milanovich, J.A., and Coleman, R.R., 2007, 2005 minerals yearbook-Salt: U.S. Geological Survey, March 2007, accessed on September 10, 2009 at http://minerals.er.usgs.gov/minerals/pubs/commodity/salt/salt_myb05. $p d f$.

Kuemmel, D.A. and Hanbali, R.M., 1992, Accident analysis of ice control operations-Final report, June 1, 1992: Marquette University, Department of Civil and Environmental Engineering, Milwaukee, Wisconsin, 24 p., accessed on September 10, 2009 at www.trc.marquette.edu/ publications/IceControl/ice-control-1992.pdf.

Kunze, A.E., and Sroka, B.N., 2004, Effects of deicing chemicals on shallow unconsolidated aquifers in Ohio, final report: U.S. Geological Survey Scientific Investigations Report 2004-5150, $187 \mathrm{p}$.

Lapham, W.W., Hamilton, P.A., and Myers, D.N., 2005, National water-quality assessment program-Cycle II regional assessments of aquifers: U.S. Geological Survey Fact Sheet 2005-3013, 4 p.

Michigan Department of Environmental Quality, 1994, Salt, a Michigan resource: Lansing, Michigan, Michigan Department of Environmental Quality, 2 p., accessed on September 10, 2009 at www.deq.state.mi.us/documents/deqogs-gimdl-GGSB.pdf.

Minnesota Department of Transportation, 2006, Snow and ice fact sheet, winter 2005-2006, Office of Communications, 2 p., accessed at http://www.dot.state.mn.us/workzone/snowicefacts.pdf.

Mullaney, J.R., Mondazzi, R.A., and Stone, J.R., 1999, Hydrogeology and water quality of the Nutmeg Valley area, Wolcott and Waterbury, Connecticut: U.S. Geological Survey Water-Resources Investigations Report 99-4081, 90 p., 2 pl.

Mullaney, J.R., Schwarz, G.E., and Trench, E.C.T., 2002, Estimation of nitrogen yields and loads from basins draining to Long Island Sound, 1988-98: U.S. Geological Survey Water-Resources Investigations Report 02-4044, 84 p.
Nakagaki, N., and Wolock, D.M., 2005, Estimation of agricultural pesticide use in drainage basins using land cover maps and county pesticide data: U.S. Geological Survey OpenFile Report 2005-1188, 46 p.

National Atmospheric Deposition Program (NRSP-3), 2006, NADP Program Office, Illinois State Water Survey, 2204 Griffith Dr., Champaign, Illinois 61820.

Nimiroski, M.T., and Waldron, M.C., 2002, Sources of sodium and chloride in the Scituate Reservoir Drainage Basin, Rhode Island: U.S. Geological Survey Water-Resources Investigations Report 02-4149, $16 \mathrm{p}$.

Norris, S.E., 1978, Hydrologic environment of the Silurian salt deposits in parts of Michigan, Ohio, and New York: U.S. Geological Survey Open-File Report 78-684, 31 p.

Ostendorf, D.W., Hinlein, E.S., Rotaru, C., and DeGroot, D.J., 2006, Contamination of groundwater by outdoor highway deicing agent storage: Journal of Hydrology, v. 326, p. 109-121.

Panno, S.V., Hackley, K.C., Hwang, H.H., Greenberg, S.E., Krapac, I.G., Landsberger, S., and O'Kelly, D.J., 2006, Characterization and identification of $\mathrm{Na}-\mathrm{Cl}$ sources in ground water: Ground Water, v. 44, no. 2, p. 176-187.

Peavy, H.S., 1978, Groundwater pollution from septic tank drainfields - A report to the Blue Ribbons of the Big Sky Country Areawide Planning Organization: Bozeman, Montana, Dept. of Civil Engineering and Engineering Mechanics, Montana State University.

Peters, N.E., 1984, Evaluation of environmental factors affecting yields of major dissolved ions of streams in the United States: U.S. Geological Survey Water-Supply Paper 2228, $39 \mathrm{p}$.

Peters, N.E., 1991, Chloride cycling in two forested lake watersheds in the west-central Adirondack mountains, New York, U.S.A.: Water, Air, and Soil Pollution, v. 59, p. 201-215.

Prisloe, M., Wilson, E.H., Arnold, C., 2003, Final reportRefinement of population-calibrated land-cover-specific impervious surface coefficients for Connecticut: Nemo FY02 Workplan, DEP project 01-08, University of Connecticut, Middlesex County Extension Center, 20 p.

Rao, U., Hollocher, K., Sherman, J., Eisele, I., Frunzi, M.N., Swatkoski, S.J., and Hammons, A.L., 2005, The use of $36 \mathrm{Cl}$ and chloride/bromide ratios in discerning salinity sources and fluid mixing patterns - A case study at Saratoga Springs: Chemical Geology, v. 222, p. 94-111. 
Robinson, K.W., Lazaro, T.L., and Pak, C., 1996, Associations between water-quality trends in New Jersey streams and drainage-basin characteristics, 1975-1986: U.S. Geological Survey Water-Resources Investigations Report 96-4119, $148 \mathrm{p}$.

Rosen, M.R., Lapham, W.W., 2008, Introduction to the U.S. Geological Survey National Water-Quality Assessment (NAWQA) of ground-water quality trends and comparison to other national programs: Journal of Environmental Quality, v. 37, S-190-S-198.

Runkel, R.L., Crawford, C.G., Cohn, T.A., 2004, Load estimator (LOADEST) - A FORTRAN program for estimating constituent loads in streams and rivers: U.S. Geological Survey Techniques and Methods, book 4, chap. A5, 69 p.

Savoca, M.E., Sadorf, E.M., Linhart, S.M., and Akers, K.K.B., 2000, Effects of land use and hydrogeology on the water quality of alluvial aquifers in eastern Iowa and southern Minnesota, 2000: U.S. Geological Survey Water-Resources Investigations Report 99-4246, 38 p.

Smith, R.A., Alexander, R.B., and Wolman, M.G., 1987, Water-quality trends in the Nation's rivers: Science, v. 235, p. 1607-1615.

Sullivan, D.J., 2000, Nutrients and suspended solids in surface waters of the Upper Illinois River basin in Illinois, Indiana, and Wisconsin, 1978-97: U.S. Geological Survey Water Resources Investigations Report 99-4275, 57 p.

Thomas, M., 2000, The effect of residential development on ground-water quality near Detroit, Michigan: Journal of the American Water Resources Association, v. 36, no. 5, p. 1023-1038.

Transportation Research Board, 1991, Highway deicingComparing salt and calcium magnesium acetate: Washington, D.C., Transportation Research Board National Research Council, 1991 Special Report 235, 168 p., accessed August 4, 2006, at http://onlinepubs.trb.org/ onlinepubs/sr/sr235/149-158.pdf.

Trench, E.C.T., 1996, Trends in surface-water quality in Connecticut, 1969-88: U.S. Geological Survey WaterResources Investigations Report 96-4161, 176 p.

U.S. Department of Commerce, 1991, 1990 census of population and housing, summary population and housing characteristics, Connecticut: Washington, D.C., Bureau of the Census, publication 1990/CPH-1-8, 64 p.

U.S. Environmental Protection Agency, 1988, Ambient water quality criteria for chloride-1988: U.S. Environmental Protection Agency Office of Water Regulations and Standards 440/5-88-001, 47 p., accessed December 17, 2007, at http://www.epa.gov/ost/pc/ambientwqc/chloride1988.pdf.
U.S. Environmental Protection Agency, 1992, Secondary drinking water regulations - Guidance for nuisance chemicals: EPA 810/K-92-001 accessed June 13, 2006, at http:// www.epa.gov/safewater/consumer/2ndstandards.html.

U.S. Environmental Protection Agency, 2004, 2004 edition of the drinking water standards and health advisories: Office of Water, U.S. Environmental Protection Agency, Washington, DC, EPA 822-R-04-005, 12 p., accessed on September 10, 2009 at www.epa.gov/waterscience/criteria/ drinking/dwstandards2004.pdf.

U.S. Environmental Protection Agency, 2007, Permit Compliance System database, accessed December 17, 2007, at http://www.epa.gov/waterscience/basins/.

U.S. Geological Survey, 2005a, Active mines and mineral processing plants in the United States in 2003: U.S. Geological Survey, Web page accessed March 20, 2009, at http://tin. er.usgs.gov/metadata/mineplant.faq.html.

U.S. Geological Survey, 2005b, Salt statistics, in Kelly, T.D., and Matos, G.R., comps., Historical statistics for mineral and material commodities in the United States: U.S. Geological Survey Data Series 140, accessed January 16, 2006, at http://pubs.usgs.gov/ds/2005/140/.

Vogelmann, J.E., Sohl, T.L., Campbell, P.V., Shaw, D.M., 1998, Regional land cover characterization using LANDSAT thematic mapper data and ancillary data sources: Environmental Monitoring and Assessment, v. 51, p. 415-428.

Warner, K.L., and Arnold, T.L., 2005, Framework for regional synthesis of water-quality data for the glacial aquifer system in the United States: U.S. Geological Survey Scientific Investigations Report 2005-5223, 6 p.

Wenck Associates Inc., 2004, Chloride TMDL report prepared for Shingle Creek Water Management Commission and the Minnesota Pollution Control Agency: City of Maple Plain, Minnesota, [variously paginated.]

Wolock, D.M., 1993, Simulating the variable-source-area concept of streamflow generation with the watershed model TOPMODEL: U.S. Geological Survey Water-Resources Investigations Report 93-4124, 33 p.

Wolock, D.M., 2003, Estimated mean annual natural recharge in the conterminous United States: U.S. Geological Survey Open-File Report 03-311.

Wulkowicz, G.M., and Saleem, Z.A., 1974, Chloride balance of an urban basin in the Chicago area: Water Resources Research, v. 10, no. 5, p. 974-982. 



\section{Appendix 1}




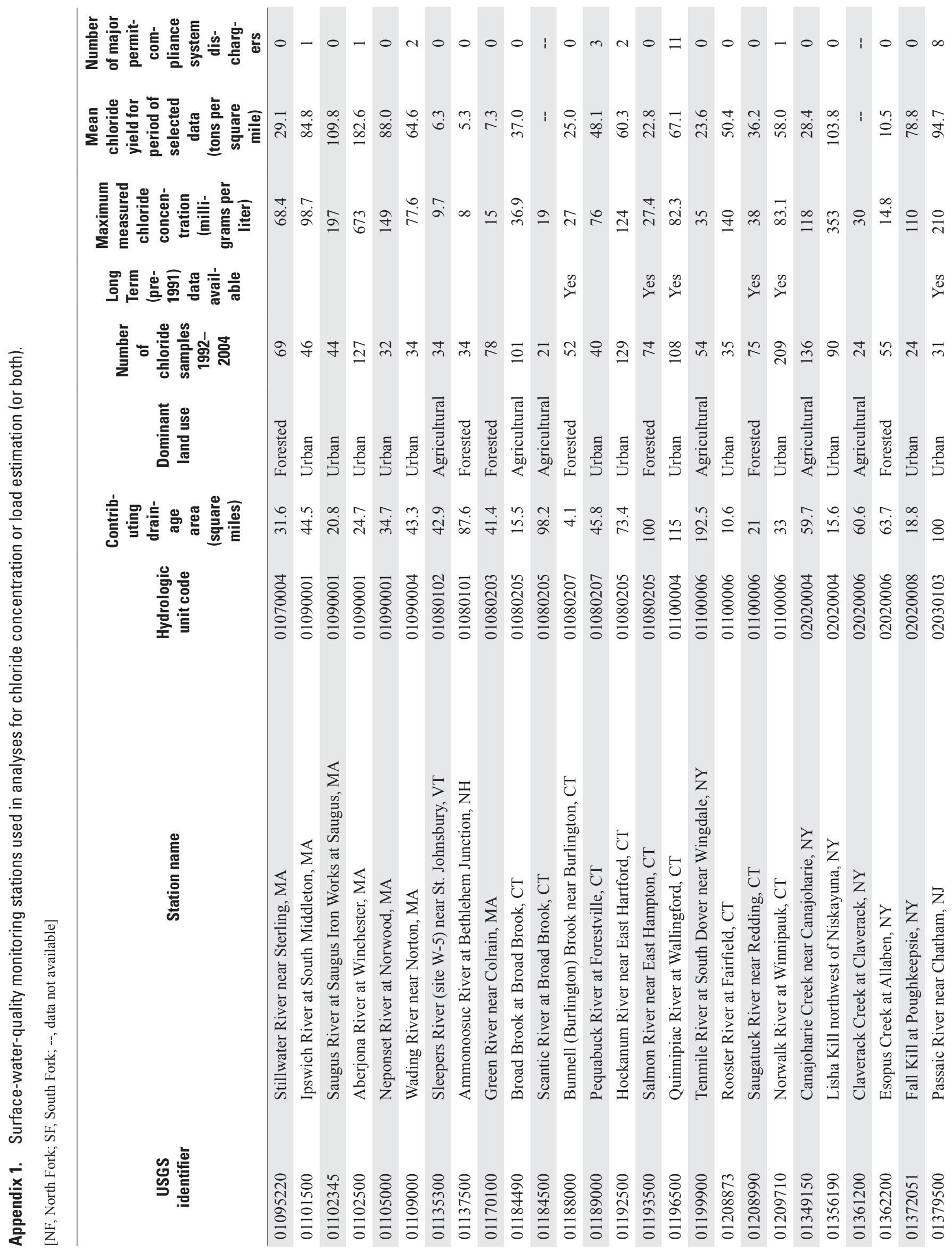




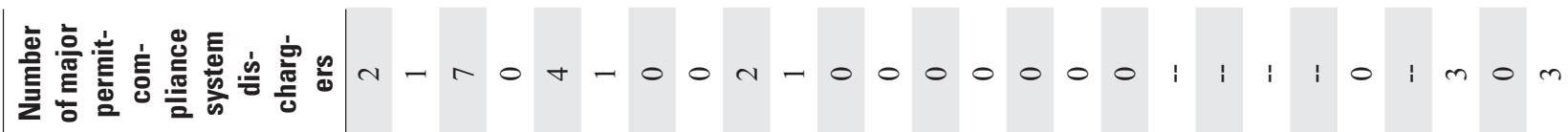

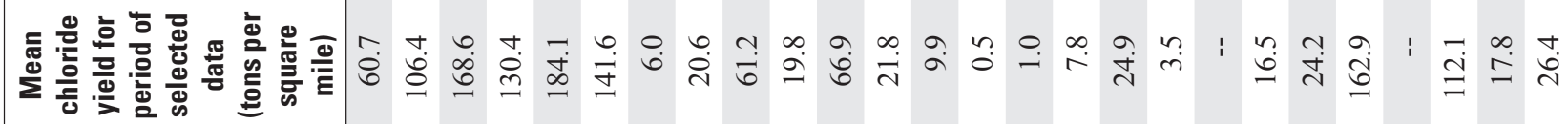

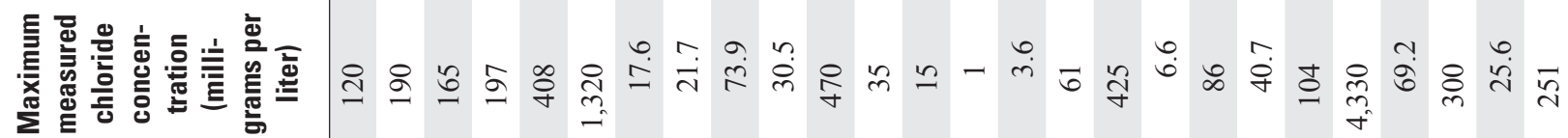

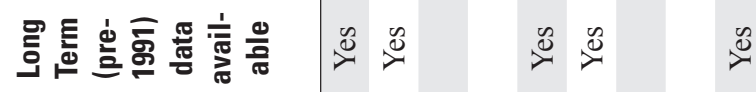

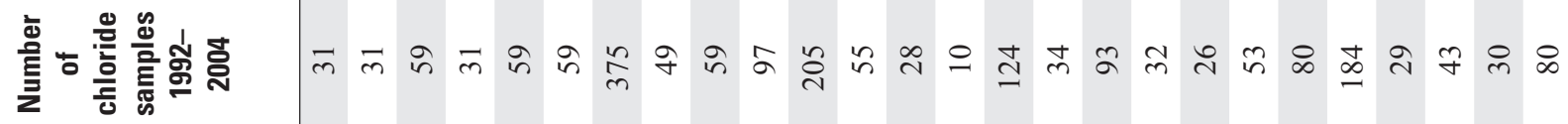
产兽

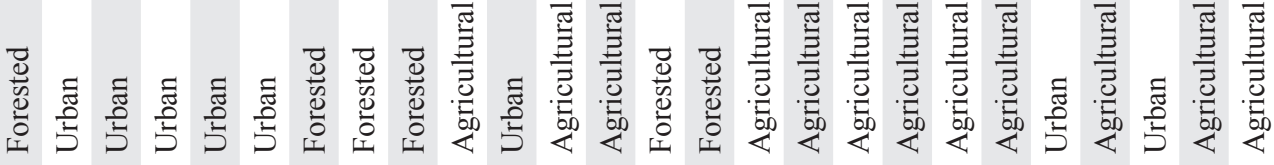

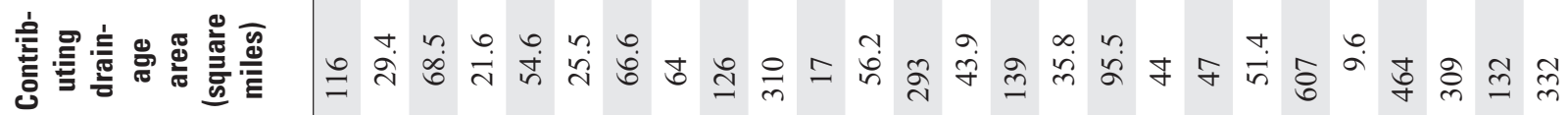

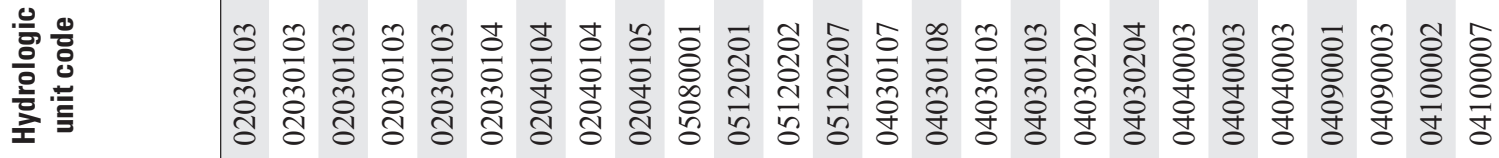

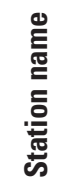

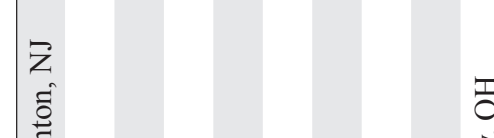

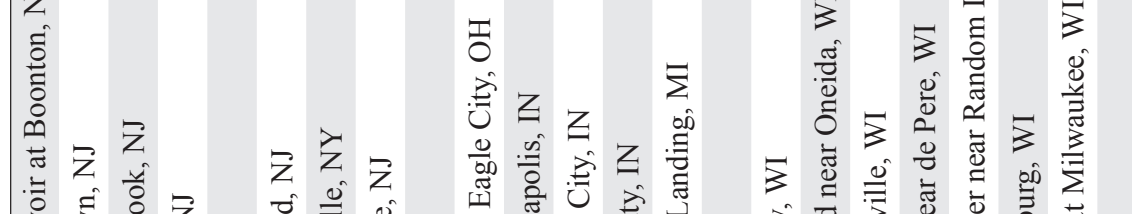

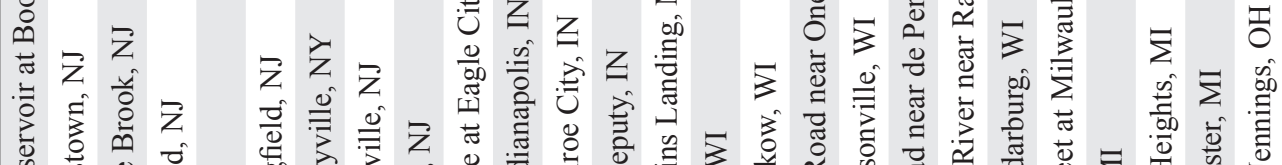

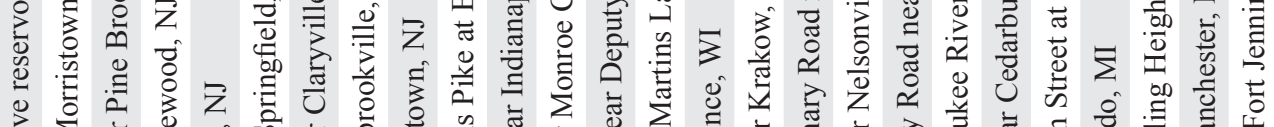

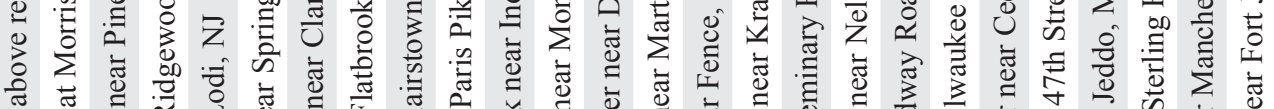
ब

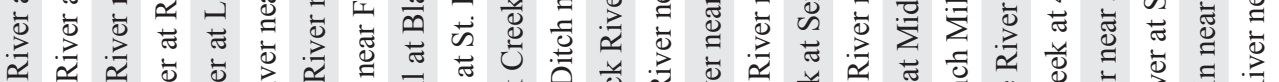

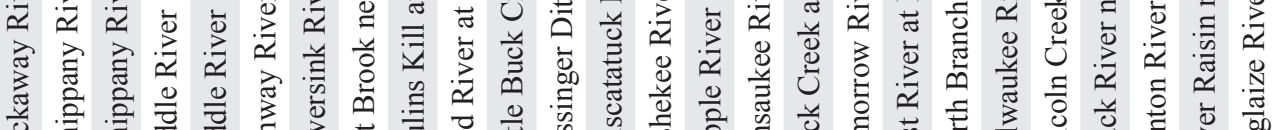

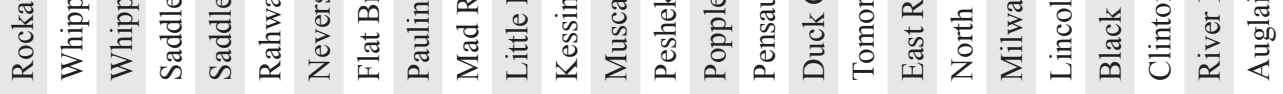

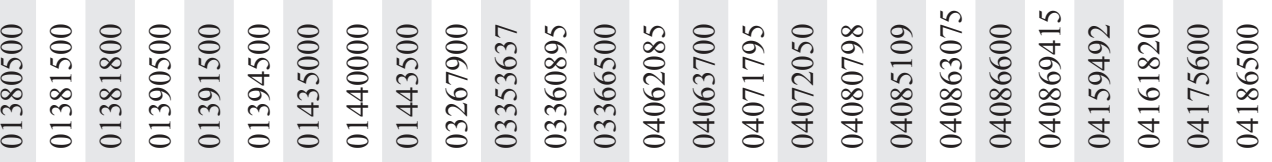




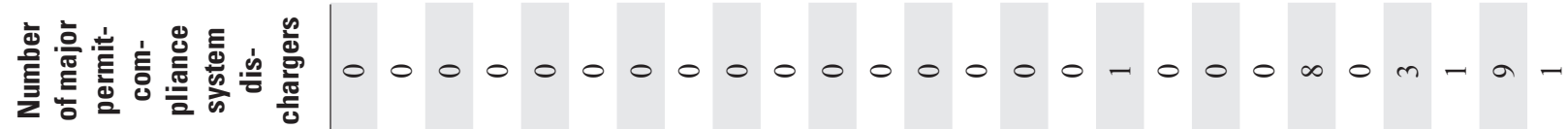
产

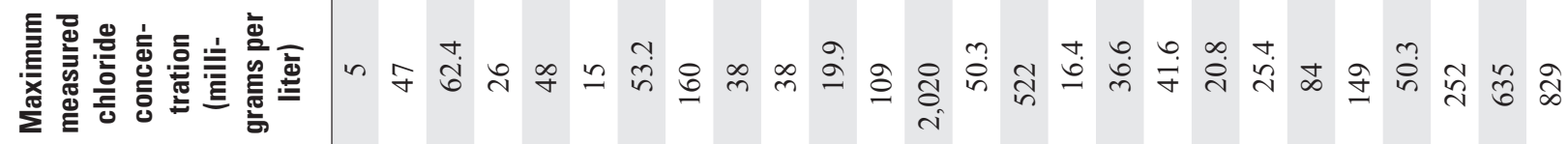

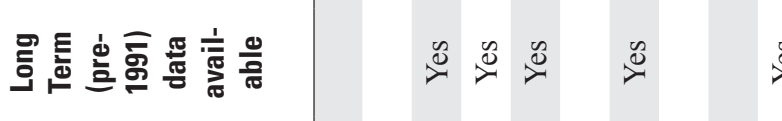

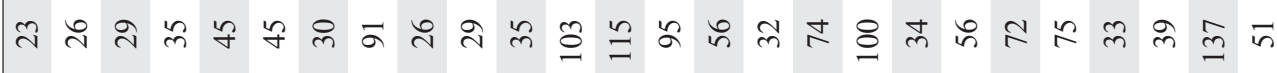

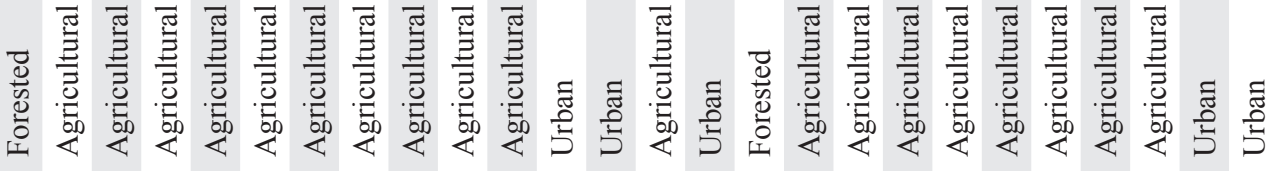

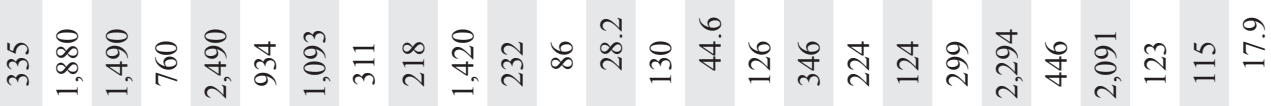

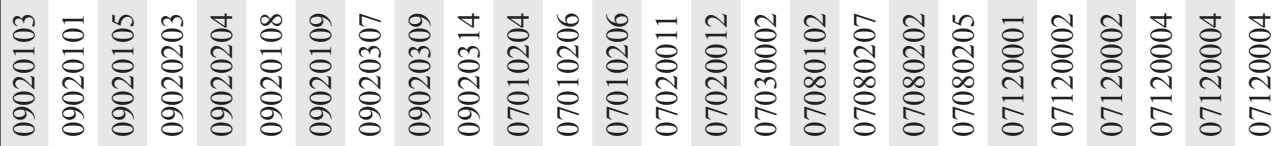

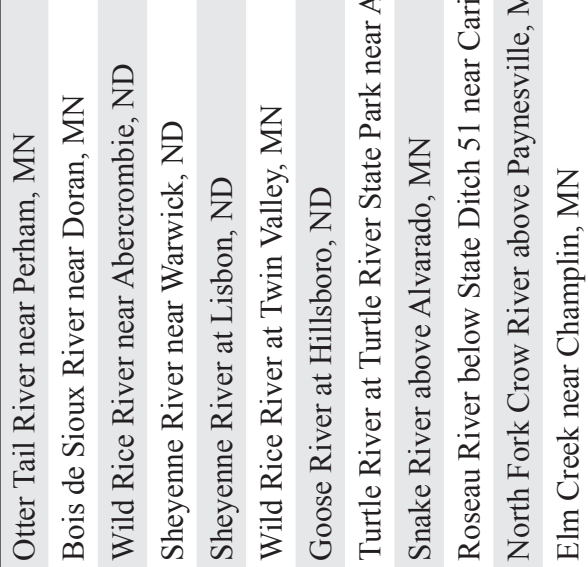

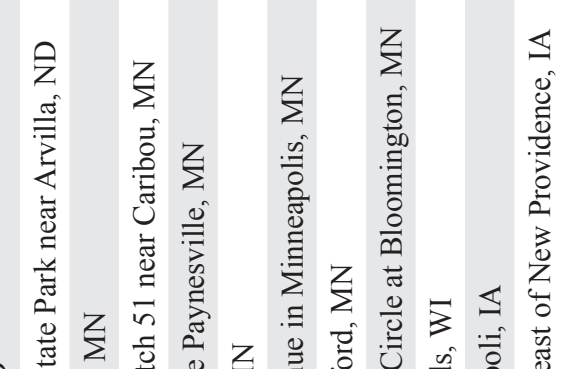




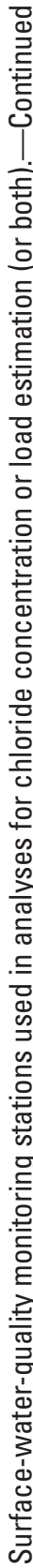

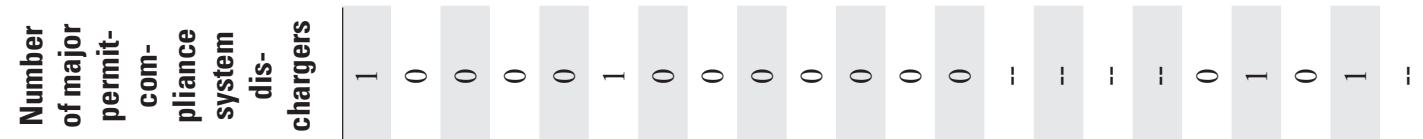

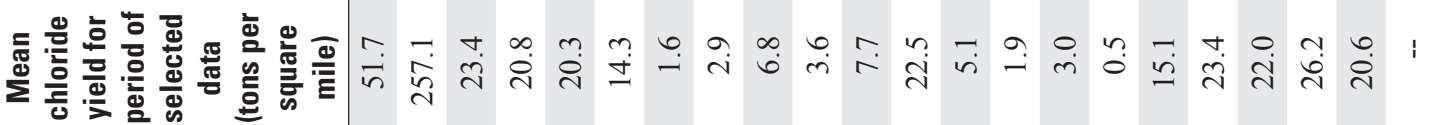

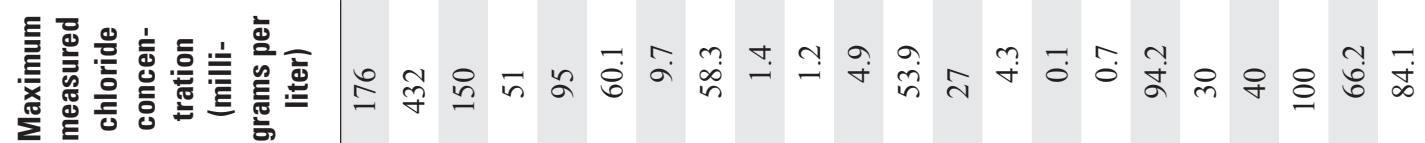

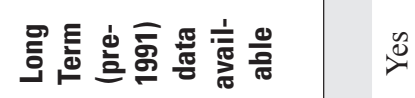

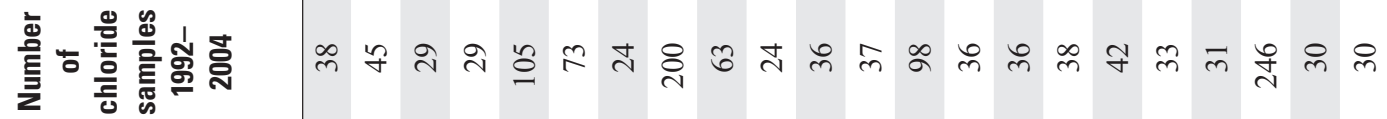

䓂兽

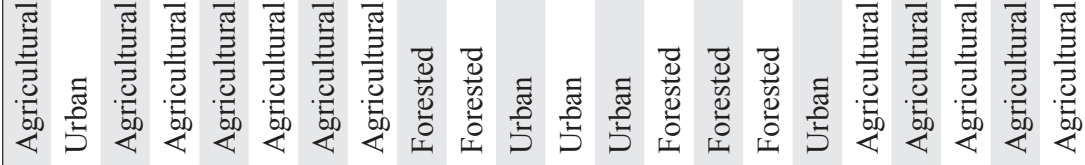

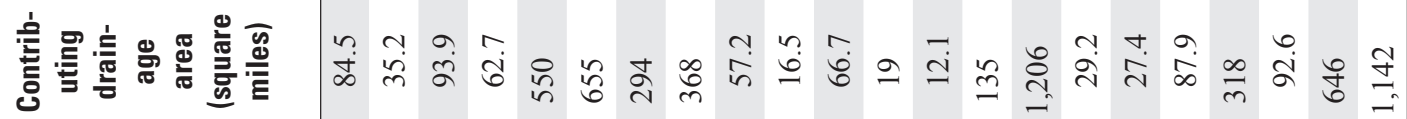

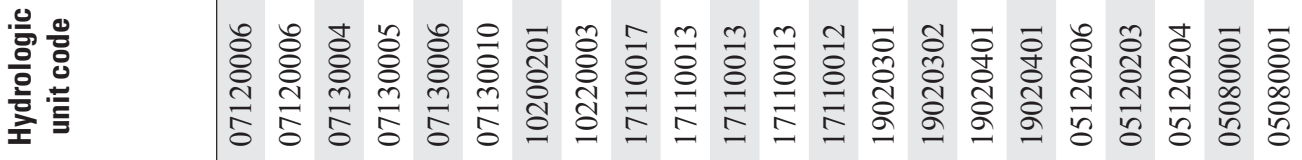



Prepared by the Pembroke Publishing Service Center.

For more information concerning this report, contact:

Director

U.S. Geological Survey

Connecticut Water Science Center

101 Pitkin Street

East Hartford, CT 06108

dc_ct@usgs.gov

or visit our Web site at:

http://ct.water.usgs.gov 
Science Center Director

USGS Connecticut Water Science Center

101 Pitkin Street

East Hartford, CT 06108

http://ct.water.usgs.gov

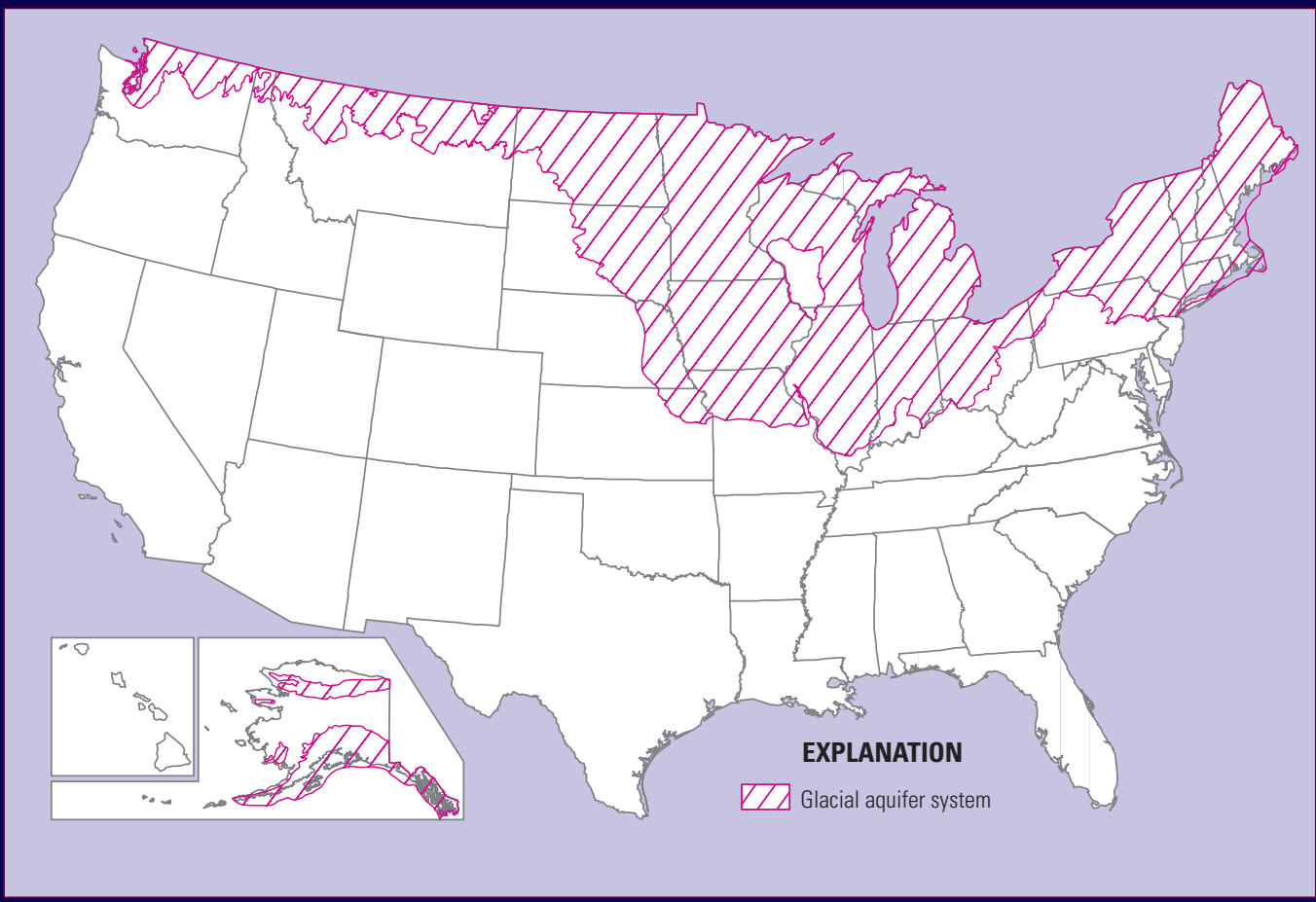

